\title{
FINANCE and DEVELOPMENT
}

www.imf.org/fandd June $2010 \$ 8.00$ 
Finance \& Development is published quarterly in English, Arabic, Chinese, French, Russian, and Spanish by the International Monetary Fund. English edition ISSN 0015-1947

\section{EDITOR-IN-CHIEF}

Jeremy Clift

MANAGING EDITOR

Marina Primorac

\section{SENIOR EDITORS}

Camilla Andersen

Hyun-Sung Khang

James Rowe

Simon Willson

ASSISTANT EDITORS

Maureen Burke

Jacqueline Deslauriers

Natalie Ramirez-Djumena

CREATIVE DIRECTOR

Luisa Menjivar

ART EDITOR

Lai Oy Louie

EDITORIAL ASSISTANTS

Lijun Li

Niccole Braynen-Kimani

Harris Qureshi

\section{ADVISORS TO THE EDITOR \\ Bas Bakker \\ Helge Berger \\ Tim Callen \\ Adrienne Cheasty \\ Ana Corbacho \\ Alfredo Cuevas \\ Marcello Estevão \\ Domenico Fanizza \\ James Gordon \\ Thomas Helbling \\ Paul Hilbers \\ Paolo Mauro \\ Gian Maria Milesi-Ferretti \\ Paul Mills \\ Uma Ramakrishnan \\ Rodney Ramcharan}

Postmaster: please send changes of address to Finance \& Development, International Monetary Fund, Washington, DC, 20431, USA Periodicals postage is paid at Washington, DC, and at additional mailing offices.

The English edition is printed at United Lithographers Inc., Ashburn, VA.

(c) 2010 by the International Monetary Fund. All rights reserved. If you wish to reproduce any content found in this issue of $F \& D$, please submit a request for permission via the online form, which may be found at www.imf.org/external/terms.htm or send your request by e-mail to copyright@imf.org. Permission for commercial purposes may also be secured online from the Copyright Clearance Center at its website,

www.copyright.com. A nominal fee will be collected for this service.

Opinions expressed in articles and other materials are those of the authors; they do not necessarily reflect IMF policy.

Subscriber services,

Changes of address, and

Advertising inquiries

IMF Publication Services

700 Nineteenth Street, NW

Washington, DC, 20431, USA

Telephone: (202) 623-7430

Fax: (202) 623-7201

E-mail: publications@imf.org

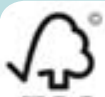

\section{FEATURES}

\section{ASIA'S GROWING INFLUENCE}

\section{$4 \quad$ Asia Leading the Way}

Asia is moving into a leadership role in the world economy Anoop Singh

\section{A Stronger China}

China can emerge from the crisis stronger if it increases domestic demand and promotes global integration Linda Yueh

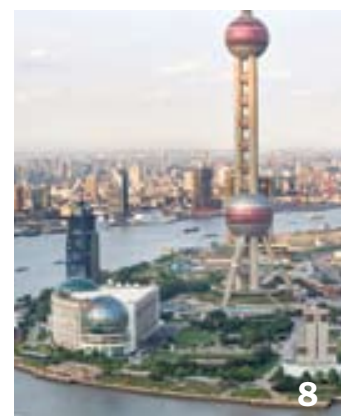

12 Min Zhu on Asia's Economy and More

The Special Advisor to the IMF's Managing Director talks about Asia in the global economy, the global financial crisis, and the IMF in Asia

14 Deeper Markets, Cheaper Capital

Financial sector reforms can help reduce the cost of capital, spur investment, and promote rebalancing in Asia

Sanjay Kalra

16 Serving Up Growth

Promoting the services sector in Asia is another way to restore balance and boost growth Olaf Unteroberdoerster

18 People in Economics: The Unlikely Revolutionary

Hyun-Sung Khang profiles Korean crusader Jang Hasung

\section{ALSO IN THIS ISSUE}

\section{After the Fall}

As the debate over how best to manage monetary policy heats up, the oncesharp difference between advanced and emerging economies is blurring Eswar Prasad

\section{$\underline{26}$ Redefining Central Banking}

Central banks must distill lessons from the global crisis and make concrete reforms

Duvvuri Subbarao

\section{Principles for Reform}

In designing new policies for the financial sector, old-fashioned ideas are important William Poole

30 Debt and Democracy

Democracies use windfalls from international commodity price booms to reduce external debt. Autocracies tend to spend them

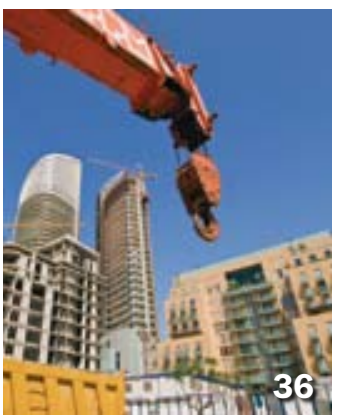
Rabah Arezki and Markus Brückner

33 Municipal Bombs

Local governments on both sides of the Atlantic found themselves in a financial mess after engaging in derivatives transactions Randall Dodd

\section{Lowering Public Debt}

Many countries have slashed their public debt ratios in the past, often thanks to favorable macroeconomic conditions. They may be less lucky in the future Harald Finger and Azim Sadikov 


\section{Asia picking up the pace}

A SIA is leading the way out of global recession, in a move that seems to mark a break from the past. China and India are ahead of the pack, but they are not the only two strong performers, and Asia's economic importance is unmistakable and palpable. In our lead article in this issue of Finance \& Development, Anoop Singh, Director of the IMF's Asia and Pacific Department, says that, based on expected trends, within five years Asia's economy will be about 50 percent larger than it is today (in purchasing-power-parity terms), account for more than a third of global output, and be comparable in size to the economies of the United States and Europe. By 2030, Asian gross domestic product will exceed that of the Group of Seven industrialized countries.

Asia's recovery is a shift from the past in several respects. First, although Asia's contribution to past global recoveries was lower than that of other regions, this time the region is leading the world recovery. Second, Asia's earlier recoveries were generally export driven, but this time the Asia rebound has been reinforced by domestic demand, including not only public stimulus but also household consumption. Finally, in past recoveries capital was slow to return to Asia; this time net capital inflows to the region have surged, reflecting high levels of global liquidity as well as Asia's improved resilience and economic framework.
It is only natural, then, for Asia's voice to become increasingly influential in global economic and financial discourse. Already, six of the Group of 20 major economies are from the AsiaPacific region. Asia (including Australia and New Zealand) accounts for just over 20 percent of IMF voting shares, and this weight is certain to rise as the IMF pursues reforms to bring countries' voting shares more closely in line with their role in the world economy. With the right policies, this economic success is likely to continue and further improve living standards for Asian people-many of whom are still extremely poor-transforming the livelihoods of almost half the world's population.

In this issue we also examine a variety of topics in the wake of the global crisis, including the role of central banks, how to manage monetary policy, redesigning policies for the financial sector, and how to lower public debt. We also look at reducing energy subsidies, new opportunities for sovereign wealth funds, and the search for stability in eastern Europe. Our "People in Economics" column profiles Korean corporate governance campaigner Jang Hasung.

Jeremy Clift

Editor-in-Chief
39 Reducing the Staggering Costs of Cheap Energy Eliminating domestic energy subsidies is tricky, but oil-exporting countries that do so will see a clear payoff

\section{Dominique Guillaume and Roman Zytek}

44 Sovereign Wealth Funds in the New Normal

As the global financial crisis recedes, state-owned investment companies are well placed to seize a new set of opportunities and navigate changing risks Mohamed A. El-Erian

\section{Searching for Stability}

Eastern Europe rode a decade-long boom into a serious bust and now must figure out how to restart growth on a more even keel

Bas B. Bakker and Anne-Marie Gulde

\section{DEPARTMENTS}

\section{In Brief}

\section{Locked-in loans \\ Banking for all \\ Ray power}

\section{Picture This}

\section{Oil Subsidies: Costly and Rising}

Reducing subsidies worldwide can bring substantial environmental benefits and create much-needed fiscal space Benedict Clements, David Coady, and John Piotrowski

\section{Supply and Demand}

Irena Asmundson

\section{Book Reviews \\ Building Social Business: The New Kind of} Capitalism That Serves Humanity's Most Pressing Needs, Muhammad Yunus

Fault Lines: How Hidden Fractures Still Threaten the World Economy, Raghuram G. Rajan

On the Brink: Inside the Race to Stop the Collapse of the Global Financial System, Henry M. Paulson, Jr.

13 Bankers: The Wall Street Takeover and the Next Financial Meltdown, Simon Johnson and James Kwak

From Asian to Global Financial Crisis: An Asian Regulator's View of Unfettered Finance in the 1990s and 2000s, Andrew Sheng

\section{Data Spotlight}

\section{Credit to the Private Sector Remains Weak}

Bank credit continues to fall despite the global recovery

José M. Cartas and Martin McConagha
Illustration: Cover, Michael Gibbs; p. 22, Kelly Barrett; p. 30, Michael Gibbs p. 33, Jim Dandy/Getty Images.

Photography: p. 2, Issouf Sanogo/AFP/Getty Images, Jim Rosenberg/CGAP, Frederic J. Brown/AFP/Getty Images; pp. 4-5, Stephen Jaffe/IMF; pp. 8-9, David Shen/epa; p. 12, Michael Spilotro/IMF; pp. 14-15, How Hwee Young/ Corbis; p. 16, Ryan Pyle/Corbis; p. 18, Ahn Joo-Young; p. 36, Guido Cozzi/ Atlantide Phototravel/Corbis; p. 39, Kaveh Kazemi/Corbis; p. 42, Rungroj Yongrit/epa/Corbis; p. 43, John Warburton-Lee/JAI/Corbis; p. 44, Scott Peterson/Getty Images; p. 50, Andrej Rybczynski/epa/Corbis; pp. 52-55, Michael Spilotro/IMF 


\section{Locked-in loans}

A 200-year-old European farm credit system could soon help more West African farmers secure bank loans and get better prices for their produce. The Food and Agriculture Organization plans to extend the concept of agricultural warrantage to Burkina Faso, Mali, and Senegal after a test project boosted farm incomes and crop yields in Niger.

Under warrantage, farmers can leverage their produce inventories for credit. Instead of selling their produce immediately after

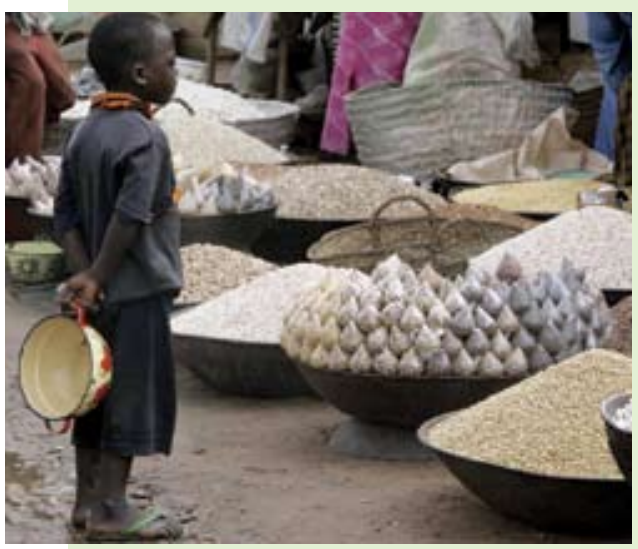

Food market in Maradi, Niger.

harvest-when prices are lowest-to generate financing for the following season, farmers can store their harvest and use it as collateral for bank credit. The produce is stored in locked warehouses secured by banks, which then extend credit based on the value of the stored harvest.

Farmers can use the up-front bank finance to purchase inputs for the next season, while also storing their harvests until deep into the off-season when produce scarcity boosts prices. When the stored produce is marketed at offseason prices, farmers can use the proceeds to pay off the banks and retain any remaining earnings as profit.

\section{Banking for all}

Half the world's population is "unbanked." This means that 2.9 billion adults do not have the opportunity to save, get loans, or manage their finances for the future.

In many Asia-Pacific Economic Cooperation (APEC) economies, the percentage of the adult population with access to a bank account is still low, with rates in Indonesia, Papua New Guinea, Peru, the Philippines, and Vietnam below 40 percent. The result is that large portions of society cannot save or get credit, or are forced to access credit at inflated prices in informal markets-for example, through loan sharks— which can lead to inescapable debt spirals.

A recent APEC

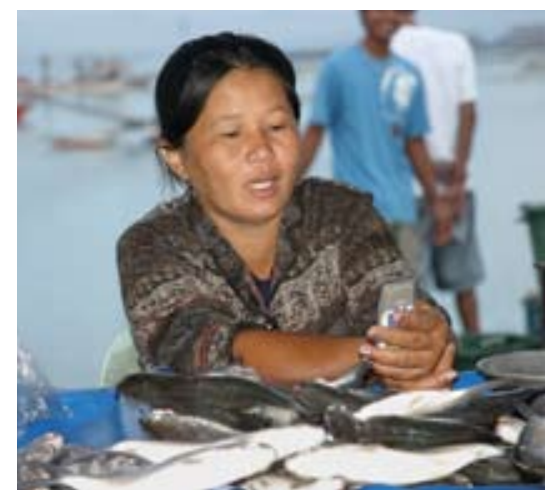

forum in Sapporo, Japan, explored possible solutions to the problem, such as expanded mobile phone banking and greater use of agent banking, a system under which retail outlets such as shops and post offices act as agents for banks.

\section{Ray power}

The Asian Development Bank (ADB) announced an Asian solar energy initiative to generate some 3,000 megawatts of solar power over the next three years.

"With energy demand projected to almost double in the Asia and Pacific region by 2030, there is an urgent need for innovative ways to generate power while at the same time reducing greenhouse gas emissions," ADB Managing Director General Rajat Nag said at the project's launch in Tashkent, Uzbekistan.

The ADB plans to provide $\$ 2.25$ billion in finance to the initiative, which is expected to spur an additional $\$ 6.75$ billion in solar power investments over the same period. Nag noted the significance of the initiative's launch in Central Asia, a region that is particularly reliant on carbon-intensive energy sources but well suited to solar energy development.

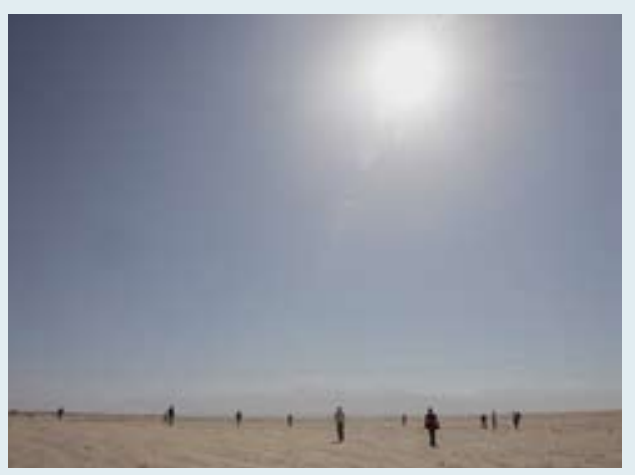

Taklamakan Desert in central Asia.

\section{Events in 2010}

June 26-27, Toronto, Canada

Group of Eight and Group of Twenty Leaders' Summit

July 12-13, Daejeon, Republic of Korea

Korea/IMF High-Level International Conference

October 9-11, Washington, D.C.

Annual Meetings of the IMF and the World Bank

October 14-15, Chengdu, People's Republic of China

Asia-Pacific Economic Cooperation Economic Leaders' Meeting

November 4-5, Washington, D.C.

IMF Eleventh Annual Jacques Polak Research Conference

November 11-12, Seoul, Republic of Korea

Group of Twenty Summit

November 16-18, Rome, Italy

Organization for Economic Cooperation and

Development Global Forum on Trade 

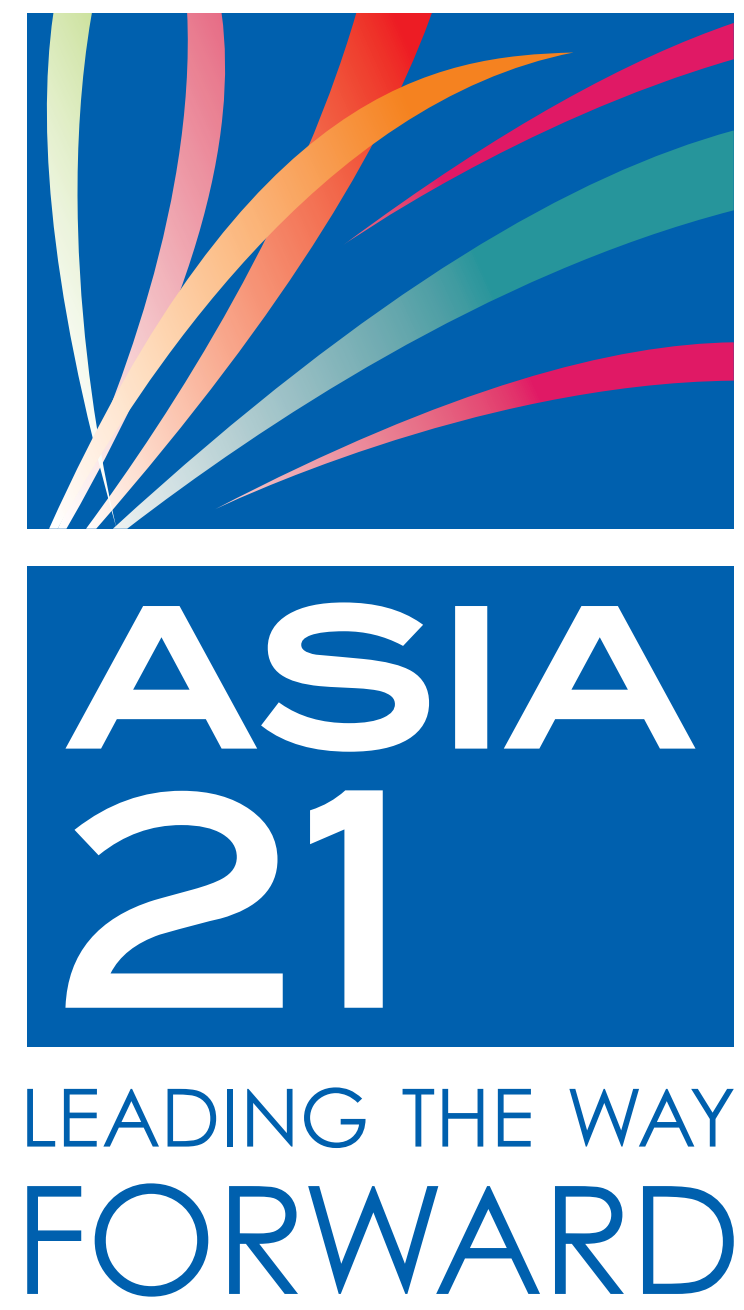

\section{KOREA/IMF HIGH-LEVEL CONFERENCE Follow the debate: www.asia21.org Daejeon, Korea • July 12-13, 2010}

Recognizing Asia's role as the most dynamic region of the world, the International Monetary Fund (IMF) is partnering with the Government of the Republic of Korea on a high-level international conference, which will be held in Daejeon, Korea on July $12 \& 13,2010$. The conference is open for full media coverage.

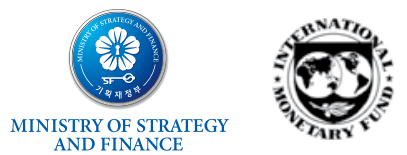

The conference will bring together senior policymakers, prominent business leaders, financial market experts, academics, civil society, and media leaders from Asia and around the world.

Online media registration is compulsory: www.asia21.org

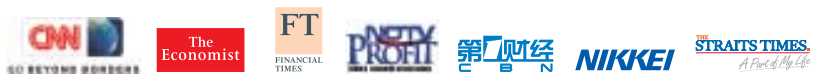




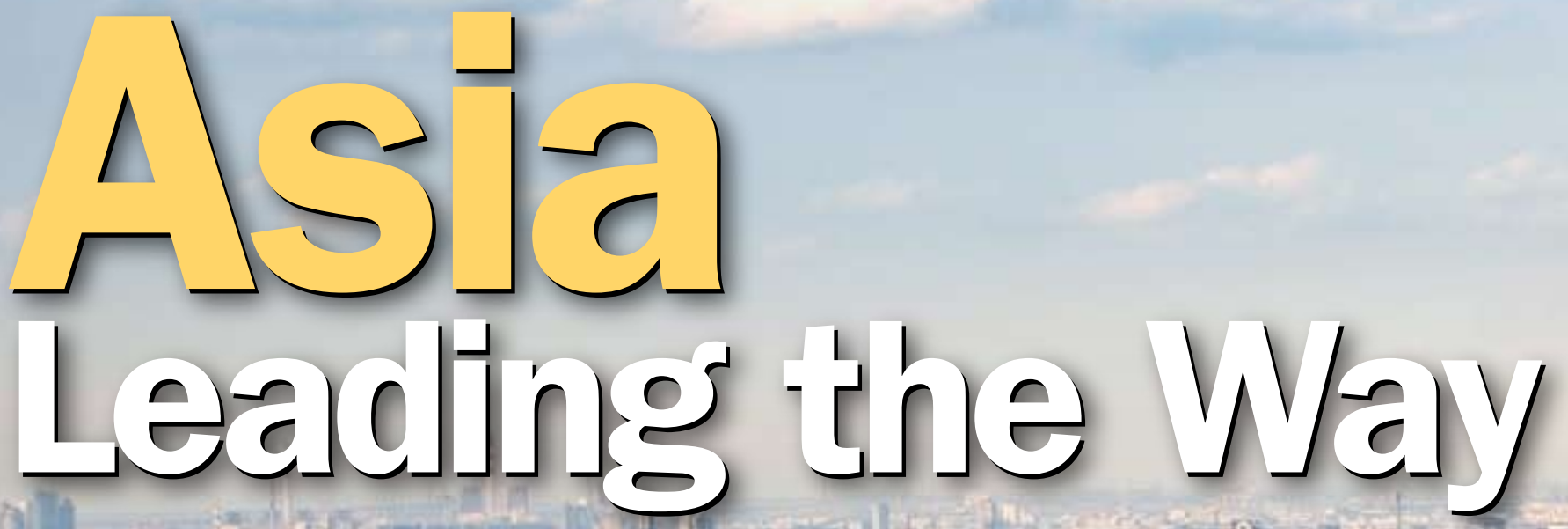

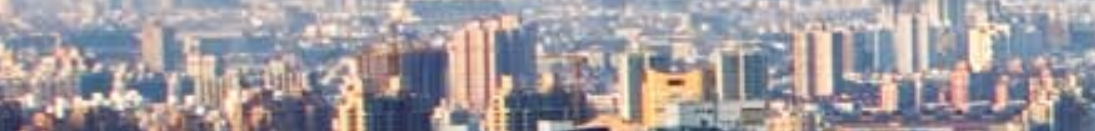

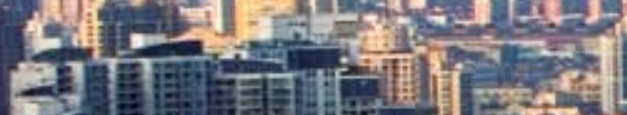

Asta is moning into a leadership role in the Would economy is:

\section{Anoop Singh}
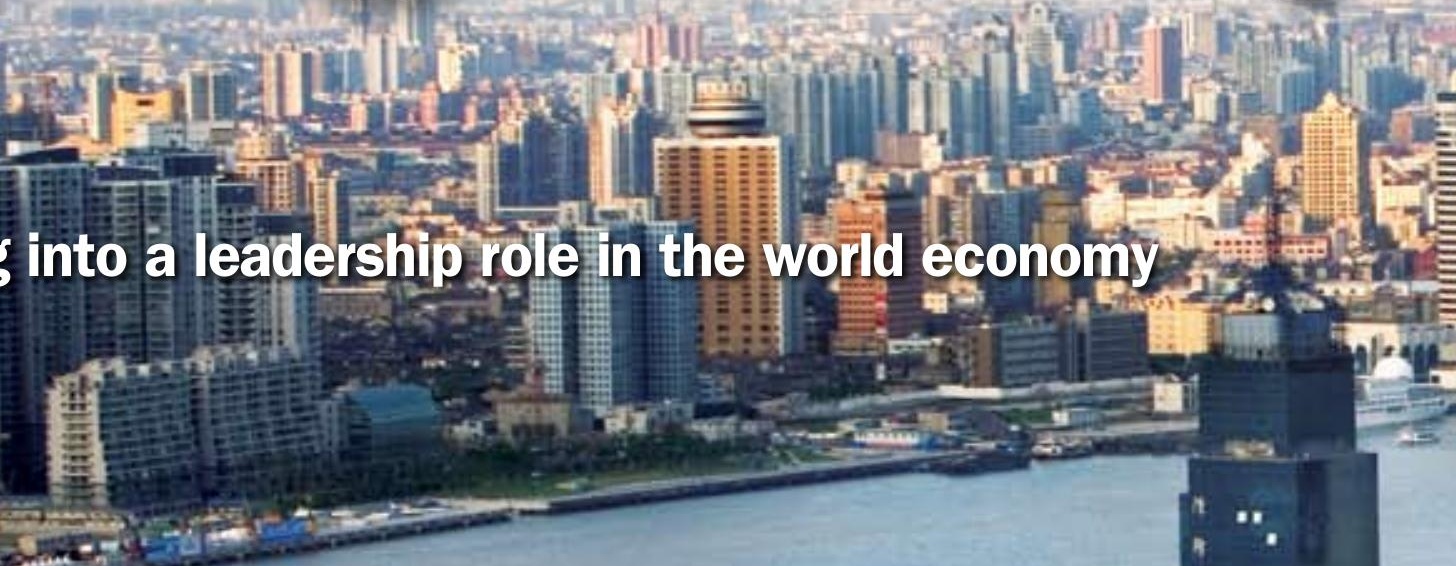

- HE recent crisis has underlined the emergence of Asta as a global economite powerhouse. Several dynamic economies in the region are generating growth outcomes that register on a global scale and are helping pull the world economy out of recession. China and India are leading the way, but the phenomenon is by no means limited to these two countries Asia's economic importance is unmistakable and palpable.

Based on expected trends, within five years Asia's economy (including Australia and New Zealand) will be about 50 percent larger than it is today (in pulschasing powerparity terms), acoount for more than a thild of global output, and be comparable in size to the economies of the United States and Europe. By 2030, Asian gross domestic product (GDP) will exceed that of the Group of Seven major industrial economies (G-7) (see Charts 1 and 2).

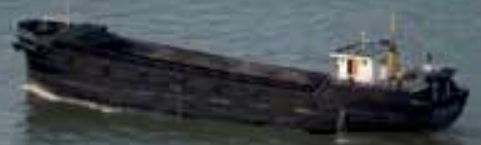




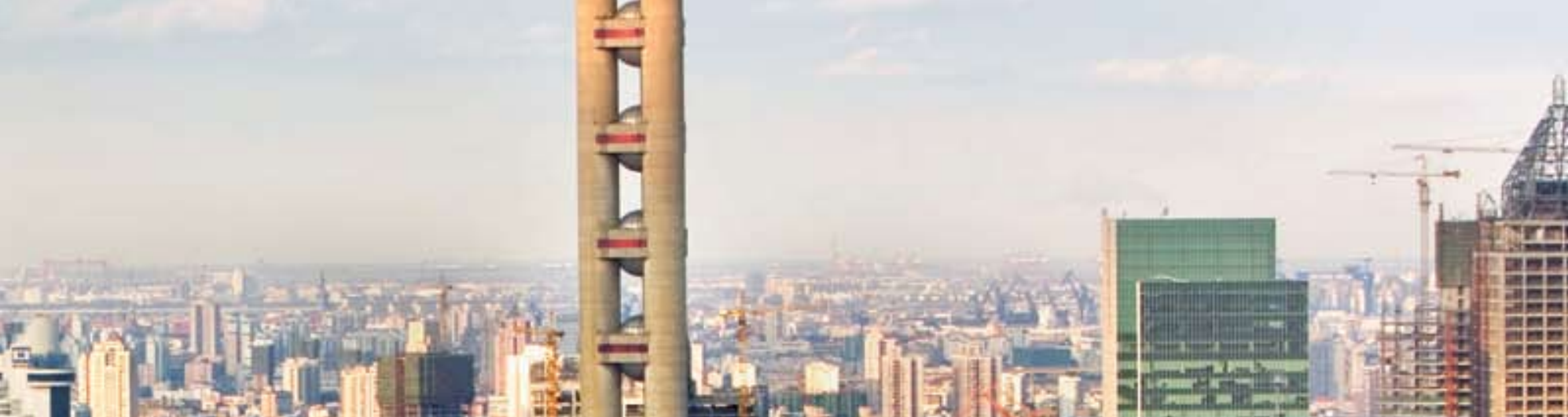

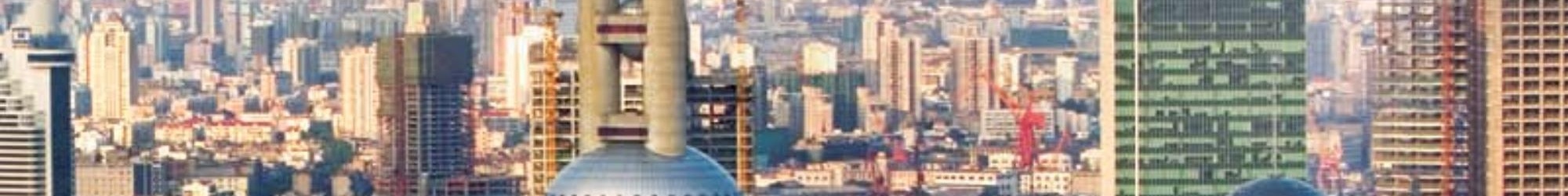

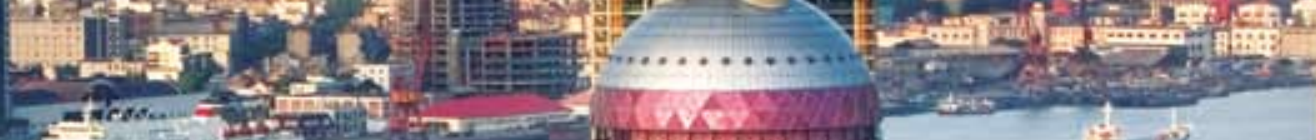

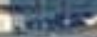
in 


\section{Chart 1}

\section{Growing influence}

Based on current trends, Asia will be the largest economic region by 2030 . (percent)

(trillion dollars, 2010 price level)$$
80
$$

Asia's share of world GDP
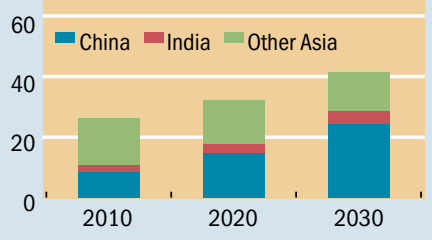

Source: IMF staff calculations.
120

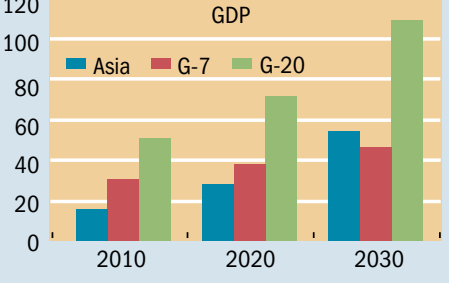

Chart 2

\section{Asia rising}

Asia's share of world trade and world GDP is increasing. (percent of world trade)

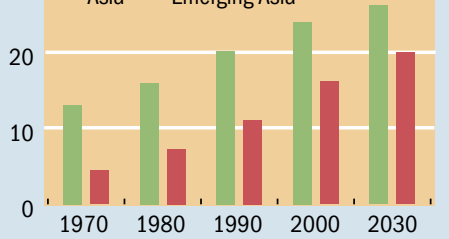

$30-$ Asia Emerging Asia (percent of world GDP)

30

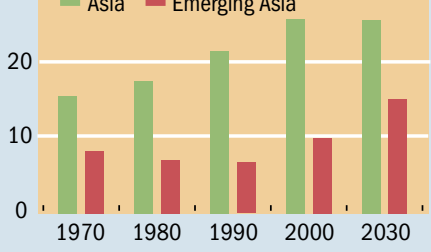

Sources: IMF, World Economic Outlook database; Direction of Trade Statistics; and IMF staff calculations.

recovery than any other region. Second, also in contrast to previous episodes, recovery in many Asian countries is being driven by two engines - exports and strong domestic demand. Strong domestic demand reflects in part policy stimulus, but resilient private demand is also a factor. All this adds up to an impression that Asia is changing in key ways and that these changes have implications for the rest of the world.

Although there are still near-term risks in the outlook, in many ways, Asia is emerging from the recession with its standing in the world strengthened. The risks include Asia's (and other regions') vulnerability to renewed negative shocks to global growth and financial markets. Nonetheless, the possibility that Asia could become the world's largest economic region by 2030 is not idle speculation. It seems very plausible, based on what Asia has already achieved in recent decades: emerging Asia's share of world trade has doubled and of world GDP tripled in just the past two decades. In addition, the strengthened policy frameworks and institutions Asia has developed, particularly over the past decade, stood up well during the recession and provide a strong foundation for the future. Furthermore, in many countries in the region, populations are relatively young and will contribute to burgeoning workforces.

It is only natural, then, for Asia's voice to become increasingly influential in global economic and financial discourse. Already, six of the Group of 20 major economies (G-20) are from the Asia-Pacific region. Asia accounts for just over 20 percent of IMF voting shares, and this weight is certain to rise as the IMF pursues reforms to bring countries' voting shares more closely in line with their role in the world economy. With the right policies, this economic success is likely to continue and further improve living standards for Asian people, transforming the livelihoods of almost half the world's population.

Consolidation of the recovery is still the main challenge for the world economy. Although Asia was not heavily exposed to the kinds of toxic securities that caused problems elsewhere, the region is an important participant in world trade, and its exports were hurt by the collapse in demand from advanced economies. The impact of the external shock was mitigated for countries with large domestic demand bases, such as China, India, and Indonesia, and some of the commodity producers, such as Australia, but the more export-oriented economies experienced particularly sharp downturns. However, economies across the region rebounded strongly, and by end-2009 output and exports had returned to precrisis levels in most of Asia, including in the hardest-hit economies.

\section{New growth frontiers}

At least two notable features mark the ongoing global recovery from Asia's perspective. First, unlike in previous global recessions, Asia is making a stronger contribution to the global
But by no means will rapid growth in the region continue automatically. Asia will need to build on its robust policy foundation with reforms to address the challenges the region still faces in both the near and the long term. In recent quarters, for example, Asia once again attracted a surge in capital flows as global investors responded to the region's stronger growth prospects. The surge in capital inflows will need to be carefully managed to prevent overheating in some economies and to avert an increase in those countries' vulnerability to credit and asset price cycles and macroeconomic volatility. However, the region could also be buffeted if shocks occur

\section{Chart 3}

\section{Relying on exports}

Asia is even more dependent on exports when measured by export value added.

(percentage points, unless otherwise indicated)

50

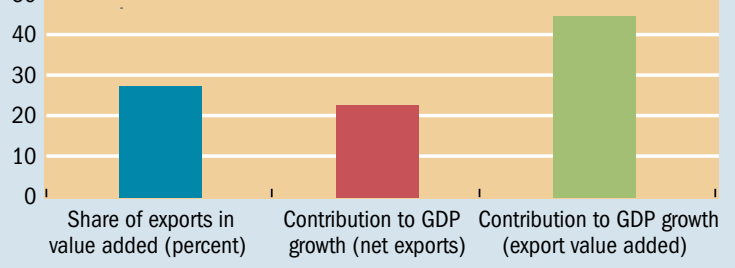

Source: IMF staff calculations

Note: Purchasing-power-parity-weighted share of exports in value added is for 2005 Contribution to growth figures are averages of contribution to three-year growth during 2001-07. 
in global financial markets, as such shocks in the past have tended to affect emerging markets all across the world.

Over the medium term, a key policy challenge for many countries in Asia is to build on domestic demand, making it a more prominent engine of growth and relying less on exports (see "Deeper Markets, Cheaper Capital," in this issue of $F \ll D$ ). This would also help manage global imbalances. More important, for many countries, the world recession has highlighted the unsustainability of tying growth too heavily to exports, which account on average for more than 40 percent of Asian growth (see Chart 3). With the recovery in advanced economies likely to be sluggish by historical standards, and their demand likely to remain below precrisis levels for some time, Asia will need to replace the shortfall in its external demand with a second, domestic source of demand if it is to sustain strong growth. Private domestic demand has contributed well to the recovery so far, but for it to continue it must be nurtured through policy. The policy measures will vary: some countries will need to increase consumption; some to sustain or increase investment, especially in infrastructure; and others must boost productivity in the service sector-all within the framework of greater trade integration in the region (see "Serving Up Growth," in this issue of $F \& D$ ). Many countries are already taking steps to improve and broaden the availability of social services, in addition to developing their financial sectors, which will help boost domestic demand. Greater exchange rate flexibility fits into this policy package by helping raise private consumption and reorient investment toward production for the domestic economy.

\section{Policy challenges}

More broadly, globalization and the reform agenda still have far to go to bring all countries and populations into the fold. Asia has made unprecedented progress in poverty reduction in recent decades, with China alone having pulled some several hundred million people out of poverty since the launch of its reforms in 1978 (see "A Stronger China," in this issue of $F \triangleleft D$ ). Nonetheless, a high proportion of the world's poor still live in Asia, and 17 percent of people in the east Asian and Pacific countries-40 percent in south Asia-live on less than

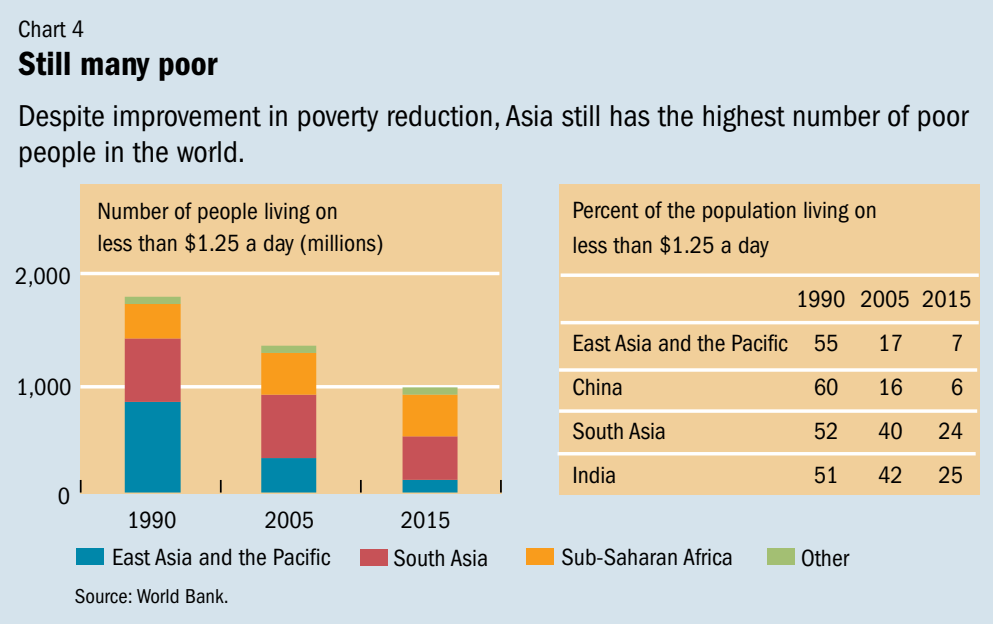

$\$ 1.25$ a day (see Chart 4). Moreover, the financial crisis has slowed poverty reduction in the region. The World Bank estimates 14 million more people in Asia will be living in poverty in 2010 as a result of the crisis. It is thus more important than ever to design and implement strategies, including reforms that enhance growth and strengthen safety nets, to alleviate endemic poverty in the region. Part of the strategy for low-income countries must include ways to move from agriculture to manufacturing as the basis for long-term growth. This will require development of national and regional infrastructure to reduce transportation costs and foster the integration of such countries into regional supply chains.

\section{Asia's time has come. Its role in the world economy continues to grow- both in world trade and finance and in economic governance... and it will grow further.}

Countries across the region are, of course, well aware of the challenges they face and are taking action on many fronts. Strengthened monetary and fiscal policy frameworks, efforts at boosting domestic demand, and deepening trade and financial linkages with other economies have been the focus of reforms. The development of infrastructure to boost the growth potential of economies is going ahead rapidly in many countries, with the help of innovative mechanisms such as public-private partnerships. Barriers to trade, including within the region, are being lifted in ways that will allow more people to enjoy the gains from international trade, including by providing new markets and customers for exporters from smaller economies. Asia is moving ahead rapidly to advance regional integration more broadly, including through intraregional groupings such as the Association of Southeast Asian Nations (ASEAN) and ASEAN+3 (including China, Japan, and Korea) and across regions, such as through the Asia-Pacific Economic Cooperation forum, with its emphasis on "open regionalism."

Asia's time has come. Its role in the world economy continues to grow-both in world trade and finance and in economic governance, through institutions such as the IMF-and it will grow further. Meanwhile, countries all over the world are interested in Asian successes in development and managing globalization. The region's economies offer a broad range of experiences from countries at various stages of development and faced with different sets of challenges, and the broader global economy can draw from them a rich set of lessons.

Anoop Singh is Director of the IMF's Asia and Pacific Department. 


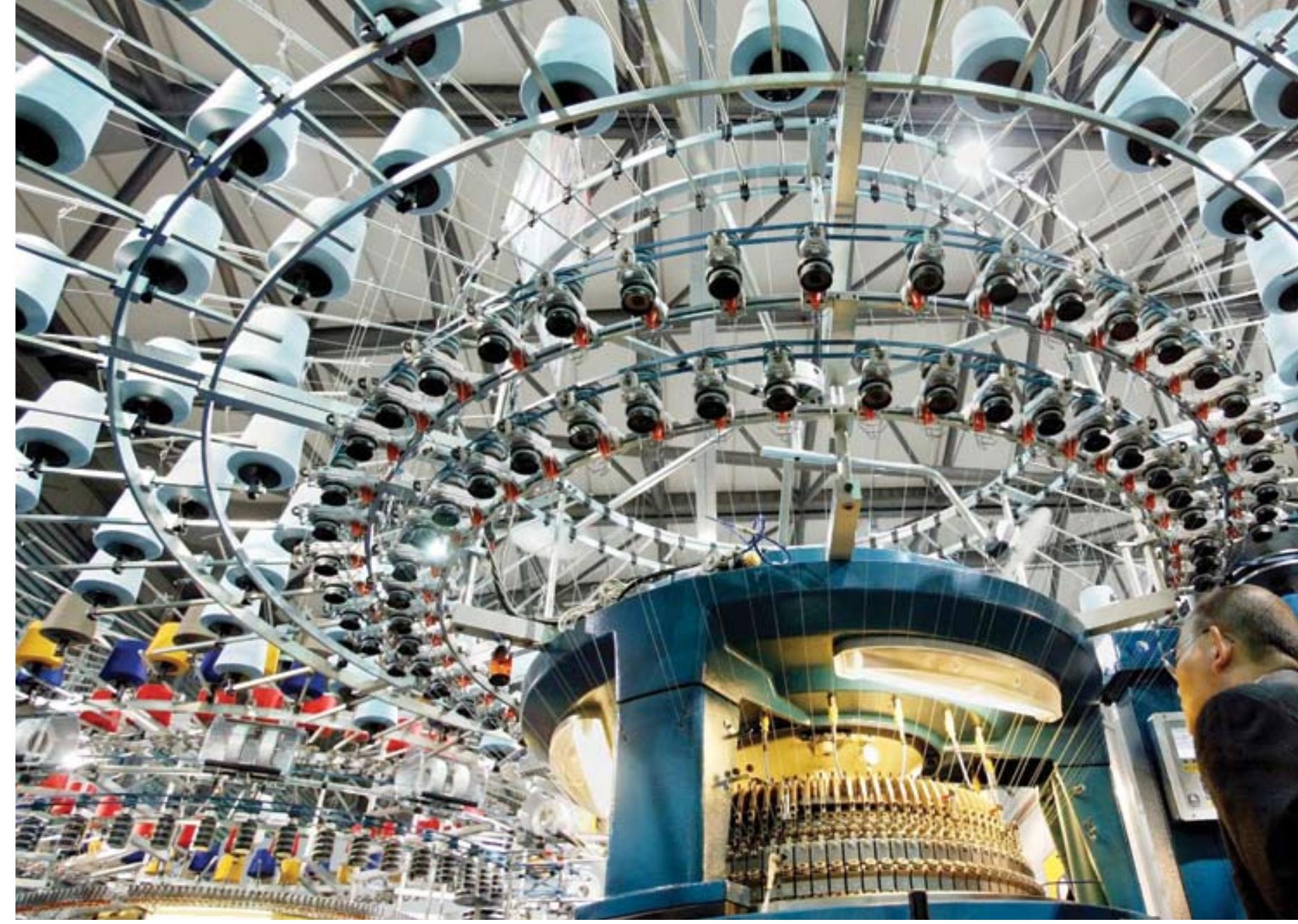

Shanghai New International Expo Center.

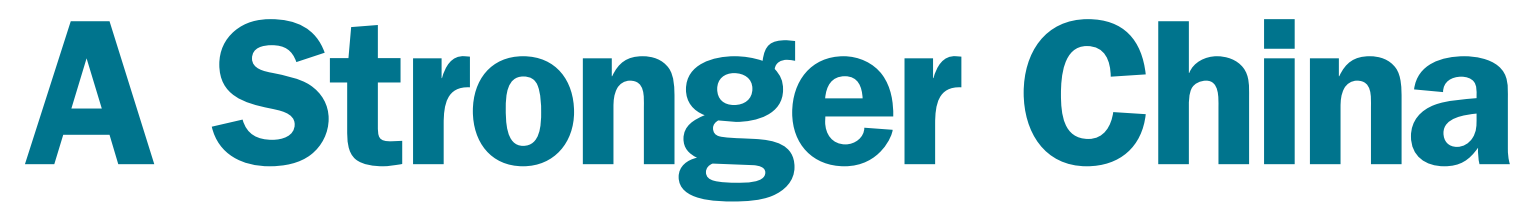

\section{Linda Yueh}

China can

emerge from the crisis

stronger if

it increases

domestic

demand and

promotes

global

integration
I $\mathrm{N}$ the West, countries are facing the fallout from a deep recession and financial crisis. Economic growth is at best tenu-

ous in advanced economies, most of which have large levels of national debt. And the euro is under pressure. Meanwhile, China's growth races ahead. Is China's seeming resilience to the recession the real deal?

China is in better shape than most countries. It averted a recession, confounding expectations by exceeding its targeted 8 percent growth rate in 2009. If it can adapt to a world economy unlikely to be driven by consumer demand from the West for the next few years, China can emerge from the global crisis stronger than ever.

\section{Surviving the crisis}

No country was immune to the global financial crisis that began in the United States in
2007. But because China's financial sector does not trade extensively in derivatives, it escaped the devastation suffered by the United States and advanced economies in Europe. China did not experience a "credit crunch" nor did it have to contend with the so-called toxic securities that devastated bank balance sheets in advanced economies. Some of China's large state-owned banks were creditors of the Wall Street investment firm Lehman Brothers, whose failure in September 2008 caused near financial panic. These stateowned banks did experience losses, estimated to be in the billions of dollars, but they avoided ongoing balance sheet impairments, which would have been far more damaging.

Still, China was affected by the second stage of the crisis: a global recession and the first contraction in global trade in 30 years. China's exports-which account for over 
30 percent of its gross domestic product (GDP) and about one-third of its annual economic growth-collapsed in late 2008. The plunge in trade cut the growth rate by about 3 percentage points in 2009 and by about 1 percentage point in the first quarter of this year. An injection of funds from the G-20 group of major economies to support trade financing has helped, but exports have yet to resume their role as a strong growth engine.

\section{Stimulus response}

As a result of the crisis and the ensuing drop in trade, China is reconsidering the importance of domestic demand as a driver of its economy, instead of relying on more volatile exports. China therefore responded to the crisis in the spring of 2009 with a $\$ 586$ billion ( $\mathrm{Y} 4$ trillion) stimulus package. The government continued to disburse the stimulus in 2010 in the face of continued weak global demand. The People's Bank of China (PBC) acted earlier, beginning to cut the policy interest rate in August 2008 when it was 7.47 percent. Its most recent cut put the rate at 5.31 percent in December 2008, where it remained as of June 2010.

This combination of stimulus package and lower interest rates helped spark pickup in growth by the second quarter of 2009. It had wallowed (for China) at about 6 percent in the final three months of 2008 and the first three months of 2009. Growth recovered to 8.7 percent for 2009 as a whole and in the fourth quarter registered an impressive 10.7 percent year-over-year growth. During the first quarter of 2010 growth spurted to 11.9 percent year over year.

China's continued growth will depend on the success of the massive fiscal stimulus, focused largely on infrastructure. Infrastructure spending builds on a large-scale transportation project in the 11th Five Year Plan, which began in 2006. The existing plan allowed the spending to be quickly implemented and provided jobs on roads and rail for some of the millions of workers laid off from export-oriented factories. Indeed, job creation does seem to be occurring, validating China's stimulus spending (Orlik and Rozelle, 2009).

But the social part of the stimulus, representing less than 5 percent of the package, was judged insufficient to stimulate private consumption. It failed to address China's high level of household saving - a major cause of low domestic demand. To discourage precautionary saving, China added $\$ 125$ billion in spending on health care later in 2009-covering
200 million uninsured citizens as a step toward achieving universal coverage by 2020 - and about $\$ 400$ million toward pensions for rural workers.

Nevertheless, consumption as a share of GDP remained constant in 2009. A 10.5 percent increase in urban incomes helped fuel consumer spending, but that increase was from a low base. Consumption accounts for only 35 percent of GDP in China, compared with 50 percent or more in most market economies. And the majority of the rural population remains poor. As a result, despite a 16 percent increase in retail sales, consumption contributed only about 4 percentage points of China's growth in 2009.

\section{Credit growth}

China, like other major economies, used aggressive fiscal policy and loose monetary policy to fight the recession. But unlike those countries, the central government financed only about one-fourth of the stimulus. State-owned banks picked up the rest. Credit grew quickly as a result. In 2009, some $\$ 1.46$ trillion (Y 9.95 trillion) in lending was granted, with another $\$ 1.09$ trillion (Y 7.5 trillion) in credit to be issued in 2010. In response, the money supply has grown nearly 30 percent. Nonetheless, consumer prices began to increase only at the end of 2009—after nine months of deflation—suggesting that the liquidity has been directed toward assets. This growth of credit in an economy with capital outflow controls means investments will be largely domestic, increasing the likelihood of asset bubbles in the stock and housing markets and generating concerns about a banking crisis.

China's sovereign wealth fund, the China Investment Corporation, recently purchased shares in the "Big Four" state-owned banks, including half of the Agriculture Bank of China. This could be viewed as an attempt to stabilize share prices-in light of worries about nonperforming loans, not a new problem in China's state-controlled banking systemand to strengthen the capital adequacy ratio of these banks. Additionally, the Big Four issued a further $\$ 11$ billion in rights in 2010 to bolster their capital base.

The pace of credit creation thus slowed in the first quarter of 2010, and the PBC increased the reserve requirements for banks. But to achieve its target of 8 percent growth when exports are unlikely to return to previous levels, China will have to persist in substituting government investment for trade, which will continue to flood the economy with liquidity. It will be difficult to achieve the combination of loose fiscal policy and tighter monetary policy needed to control asset bubbles while stimulating the economy. Moreover, the domestic banking system is not the only source of cash.

China received over $\$ 200$ billion in capital inflows in 2009, a sizable amount of which is thought to be "hot money," or investment by speculators. China's attractiveness to investors is enhanced by the undervalued renminbi, which has been pegged to the U.S. dollar since the onset of the crisis. China's reserves grew 23 percent in 2009 to a record \$2.4 trillion, two-thirds of which is in U.S. dollars.

China's recent decision to liberalize its capital account by promoting capital outflows is therefore welcome. The reforms 
will be slow, partial, and largely geared toward supporting China's "going out" or "going global" policy of encouraging Chinese firms to invest overseas. Nevertheless, these measures should help China rebalance its economy and begin to redress the world's macroeconomic imbalances.

\section{New world order}

The exacerbation of global imbalances in the 2000s served as a backdrop to the financial crisis. The rise of major emerging economies-China, India, and eastern Europe-in the early 1990s and their accelerated integration into the global economy in the 2000s increased global imbalances while doubling the world's labor force to 3 billion people. When China joined the World Trade Organization and eastern European countries joined the European Union, the lower labor costs in those nations triggered growth in their exports and had a deflationary impact on the rest of the world. But that also drove up commodity-including oil-prices, which led to greater surpluses in the Middle East as well.

Global reserve holdings have expanded fourfold since 1998, resulting in increased demand for the U.S. dollar as the global reserve currency. This boost of liquidity in the United States enhanced its consumption. It was not curtailed by the Federal Reserve, because inflation was low due in part to the growth of the global labor force (Yueh, forthcoming).

These structural changes in the global economy reinforce the need to monitor global capital movements and for central banks, including China's, to set interest rates that acknowledge asset-and not just consumer-prices. The United States in particular must also consider the reserve currency effect: because of demand for the U.S. dollar to be held in other countries' reserves, there will be downward pressure on the yield curve for U.S. treasury bills. Therefore, the cost of borrowing will be influenced not only by domestic but also by international economic conditions. For instance, tightening monetary policy may not be as easy with sustained demand for dollar assets holding down yields and pushing up the price of bonds, which keeps borrowing costs low-just as loose monetary policy led to excess liquidity when global savings helped to fuel American borrowing before the crisis. For surplus countries like China, loose U.S. monetary policy can be transmitted via fixed exchange rates, which causes capital to flow from low- to high-interest-rate economies. Thus, China should gradually reform its exchange rate to prevent domestic asset bubbles caused by liquidity inflows. Increasing the flexibility of the renminbi exchange rate before tightening monetary policy will also be important: an increase in interest rates in China while the United States maintains a near-zero policy interest rate will only worsen the liquidity inflow, eroding the impact of the tightening measure. Diversifying and reducing China's reserve holdings would also help improve global imbalances.

Global imbalances have already moderated somewhat, with the U.S. current account deficit falling from 6 percent to about 3 percent of GDP in 2009. Savings have risen in countries hit by the recession. The IMF predicts that the global economy, which contracted by 1.1 percent in 2009 , will grow $4 \frac{1}{4}$ percent in 2010 and more in 2011 . That is higher than the 3.2 percent average global growth rate from 1980 to 1997 , when China and other large emerging economies experienced rapid development. At that time, China grew 9 percent a year with a far more balanced current account than today. Correspondingly, during the same period, the U.S. current account deficit accounted for about 1.5 percent of that country's GDP, or less than 0.5 percent of world GDP, whereas today it is 3 percent of U.S. GDP, or about 0.7 percent of world GDP. Global rebalancing is likely to continue, particularly with U.S. consumption weakened by deleveraging, which implies lower surpluses for other nations.

Lower consumption in China's main export markets of the European Union and the United States means that trade growth will slow in the next few years unless there are new high-income markets for China's exports-an unlikely prospect, particularly given the problems in the euro area. If China is to return to the mostly balanced current account it had in the 1990s and sustain its growth rate, domestic demand must constitute a larger proportion of GDP.

\section{Two sides to the question}

For China to emerge stronger in the postcrisis world economy, it must institute reforms that boost domestic demand while promoting global integration, allowing China to continue to catch up in its growth rate. Given the weak global economy, reform has to transform China into a large, open economy and ensure stability during its economic transition by protecting against external shocks while increasing integration with world markets.

The Chinese economy should become more like that of the United States-a large country that is a major global trader but whose growth is driven primarily by domestic demand. If China strengthened both internal and external demand, it would be less subject to volatility in the world economy; its growth could be driven by domestic demand even as its trade expands in absolute terms. Because China affects the global terms of trade, it can redefine itself as a large, open economy that recognizes the benefits of global integration while maintaining a strong base of domestic demand to shield it from the worst external shocks.

\section{Consumption and government spending}

Consumption constituted about half of GDP until high rates of household and corporate saving drove it down to a historical low of just over one-third. But it could return to the 50 percent level of the early 1990s if the incentives for saving are addressed. For households this could be achieved by increasing social security provision, and for firms by easing credit constraints to free up lending, eliminating the need to use retained earnings for growth.

There is plenty of room for increased government spending on social security. As a share of GDP it was 13 percent in 2008 and approached the 20 percent mark in 2009 only because of the massive fiscal stimulus package. This is still below the precrisis average for Organization for Economic 
Cooperation and Development countries and much lower than in most other developing countries.

The government should also speed up urbanization, which could promote service sector growth. This would further develop the nontradable component of the economy and create jobs at the low and high ends of the skills spectrum. This fits well with the profile of the Chinese-urban and migrantlabor force. The increased income resulting from urbanizing portions of the rural population would boost consumption.

\section{Corporate savings and financial liberalization}

A series of reforms are necessary to reduce corporate savings. Savings of firms-state-owned and non-state-owned-are even higher than those of households. This was evident when China's current account surplus surpassed 10 percent of GDP after 2004. Investment maintained its share of GDP, even though investment is typically squeezed when countries develop a significant current account surplus.

China's distorted financial system forces private firms to save-mainly through retained earnings-in order to grow because they have trouble obtaining credit. But even state-owned enterprises, which have easy access to credit, save-because their profits are taxed so lightly. State-owned enterprises should pay higher taxes and dividends.

Complete liberalization of interest rates would both improve credit allocation to private firms and further reduce the savings incentive. Although interest rates were partially liberalized in 2004, when the ceiling on interbank lending rates was lifted, there are still limits on the floor of such rates, as well as a ceiling on deposit rates, distorting investment decisions. If interest rates were liberalized, it would reduce financing costs for firms and thus the need to save.

Gradual capital account liberalization, in particular the "going out" policy, will also help reduce savings if firms can operate in global markets and are allowed to access funding from better-developed overseas credit markets. In other words, firms can raise money in capital markets and not just rely on China's banking system with its controls on credit. This will not only reduce the motive for corporate saving but also cut the portion of the current account surplus that is funded through the purchase of U.S. treasury securities by allowing capital outflows in the form of investments instead of accumulated as foreign exchange reserves.

The external benefits do not end there. Capital account liberalization should also result in increased exchange rate flexibility because of increased demand for the renminbi. With enough capital outflows, appreciation pressures on the currency may even ease. The combination of exchange rate and interest rate reforms should result in a better balance between China's internal (savings-investment) and external (balance of payments) positions. The result would be a more balanced Chinese economy that would also help reduce liquidity buildup from global imbalances, as is fitting for a large, open economy.

Improving regulatory oversight will also be important. Liberalization should be accompanied by further domestic and international institutional reforms to deepen finan- cial markets. For instance, active participation in the global regulatory body, the Financial Stability Board, could increase stability if capital markets are increasingly governed by transparent rules and laws generating more certainty and depth. This would have positive implications for household and firm behavior.

\section{Because China affects the global} terms of trade, it can redefine itself as a large, open economy that recognizes the benefits of global integration while maintaining a strong base of domestic demand to shield it from the worst external shocks.

As a major economy, it is in China's interest to recognize its impact and help shape the governance of global and integrated markets because its decisions are affected by international conditions and in turn will influence the wider global context. For instance, China is an engine of growth for Asia and for commodity exporters around the world, and its exchange rate affects global prices, while its monetary conditions are affected by world financial markets.

\section{Becoming a large, open economy}

China has the capacity to become a fast-growing, large, open economy by encouraging domestic demand and developing globally competitive firms. Especially given China's still-low level of development, integrating into the global economy would benefit both China and the rest of the world. It can do so by implementing macroeconomic reforms that position China strategically in a changed, uncertain global economy. By doing so, China can emerge stronger from the global financial crisis. It is too good an opportunity to miss.

Linda Yueh is Director of the China Growth Centre and Fellow in Economics, St. Edmund Hall, University of Oxford.

\footnotetext{
References:

Bergsten, C. Fred, 2009, "The Dollar and the Deficits: How Washington Can Prevent the Next Crisis," Foreign Affairs (November/December).

Orlik, Tom, and Scott Rozelle, 2009, "How Many Unemployed Migrant Workers Are There?” Far Eastern Economic Review.

Victor, David G., and Linda Yueh, 2010, "New Global Energy Order," Foreign Affairs, January/February.

Yueh, Linda, 2009, The Law and Economics of Globalisation (London: Routledge). , forthcoming, "U.S., China and Global Imbalances," China
}

Economic Journal. 


\section{Min Zhu on Asia's Economy}

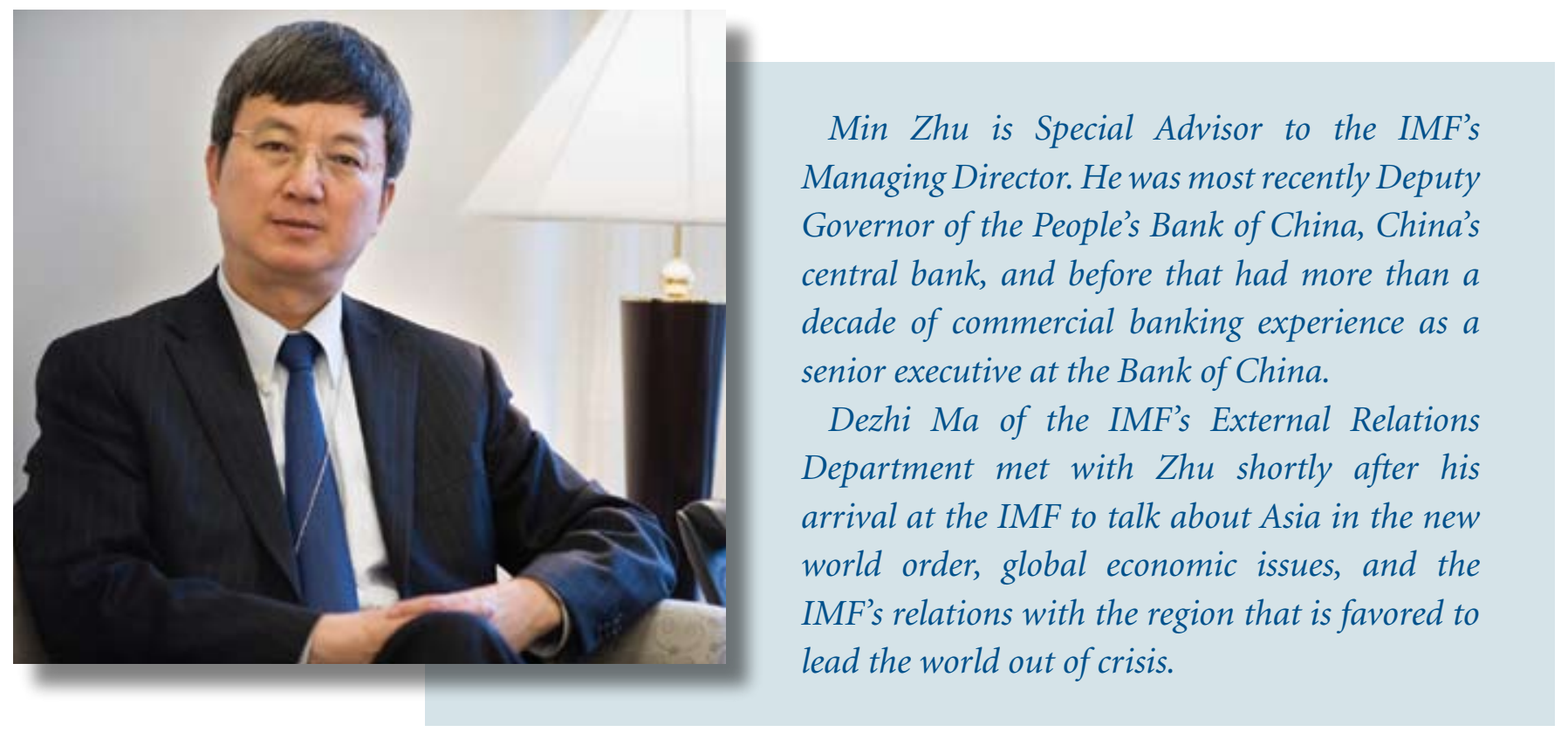

\section{Asia in the global economy}

F\&D: How do you view Asia's future in the world economy? Zhu: Asia is obviously becoming more and more important in the global economy. In 2009, the United States had GDP growth of -2.4 percent; Europe, -4.8 percent. But India had 7.3 percent growth, and China 8.7 percent. The center of growth is moving from the West to Asia, and in particular emerging Asia. I think that's a pattern that will continue for at least the next five years, which will change the whole global economic structure.

Another important change for Asia is its role in world trade. Because the crisis started in the advanced economies, trade flows from Asia to the advanced economies fell dramatically. In response, the region further strengthened intraregional trade flows. Looking forward, I believe we will see trade flows among the developing countries and emerging economies growing dramatically, and emerging Asia becoming the centerpiece of a whole new global trade pattern.

Because emerging Asia has strong growth, and advanced economies are experiencing rather weak growth, we see a multi-level, multi-speed recovery. Moreover, emerging Asia had much sounder financial situations, while the advanced economies are experiencing fiscal difficulties. So we can expect global assets to relocate, with Asia attracting more capital.

When these elements are combined, Asia will move more to the center of tomorrow's global economy.

F\&D: That seems to be an optimistic assessment from your side. Are there any big challenges, in terms of economic policy- making, for the region?

Zhu: I am optimistic about Asia's future and its growth prospects. But that doesn't mean everything is fine for Asia. Indeed, Asia is facing a lot of challenges. The recent crisis tells us that Asia is not isolated; it really is part of the global economy and finance. You see how much trade shrunk in the first quarter of 2009. You see how much capital fled in the fourth quarter of 2008. That tells Asia there are a lot of things it needs to do.

First, Asia needs to rethink its growth model. Asia still very much has an export-driven growth model. But we need to move forward to a domestic consumption-driven model to make growth much more balanced and sustainable.

A second issue is financial sector reform. The crisis taught us that a strong financial sector-which Asia does not have yet-plays a very important role in macroeconomic management. For example, Asia does not have a deep bond market, which is absolutely important for long-term financing. Asia has been working on that for years, but there is much more to be done.

Third, Asia needs to deal with global capital flows. The surge in capital flows to emerging Asia presents big challenges for the region, particularly in 2010 and for the next few years. The Asian economies need to handle this issue very carefully and design proper policies to bring lasting solutions.

So yes, on the one hand, I'm positive about the growth prospects for Asia, but on the other hand, Asia is facing a lot of challenges. 


\section{and More}

\section{Views on the crisis}

F\&D: Your experience in the private sector and as a policymaker must have given you a unique perspective on the global financial crisis. So what stands out to you?

Zhu: From my private sector experience, I can assure you that good corporate governance is very important. A company, particularly a financial company, has got to have transparency. It's got to have good risk-management systems. In particular, it has to have long-term goals rather than short-term, profit-hunting targets. Particularly in the financial sector, if you provide financial services, you really bear responsibility to the whole society.

From a policymaker's point of view, you have to keep a balance between the real economy and the financial sector. What we saw at the end of 2007 is that the financial sector was too big, and it served itself, not the real economy, which is really the reason for the financial crisis.

Looking at the macro level, I would say prudent macroeconomic management has become an important issue for all governments. In all crises you see excessive liquidity. The big lesson is that you need countercyclical, prudent macroeconomic management to prevent this type of crisis in the future.

\section{Correcting imbalances}

F\&D: How should countries work together to address the issue of global imbalances?

$Z h u$ : That's a challenging issue. Imbalances have troubled the global economy for a while now. There are many forms of imbalance: for example, the current account imbalance between emerging Asia and the advanced economies, and between the

\section{IMF in Asia}

F\&D: What do you see as the role of the IMF in Asia?

Zhu: Asia plays an important role in the IMF, and the IMF also plays an important role in Asia. I think the two sides are working closely and very well.

The IMF has a role in Asia through three channels:

- Surveillance: through Article IV consultations with countries and through the Financial Sector Assessment Program. Through surveillance, we try to assess domestic financial and economic situations, advise the domestic government, and help build growth capacity. To a few countries, we also provide liquidity as a lender of last resort.

- Capacity building: Asia is diverse, and its countries' needs are very different. The IMF offers technical assistance-on prudent macroeconomic management, growth modeling, rebalancing structure, and tax policy, to help governments handle the difficult challenges they face.

- Training and knowledge: The IMF has training centers in China, India, Malaysia, and Singapore, and offers many courses to policymakers in the region, to help countries enhance their capacity. oil-exporting countries and advanced economies. The real problem is when imbalances become big, concentrated, and persistent. In the past five years, we have seen a few countries remain persistently in surplus and a few countries persistently in deficit. Twenty years ago the top five countries accounted for 22 percent of global trade deficits. Today, the five major countries account for 76 percent. So it's very much concentrated. This is a real concern.

\section{The real problem is when imbalances become big, concentrated, and persistent.}

Obviously, we need global cooperation on these issues. There are several things that need to be done. The deficit countries need to consume less and save more, so they can import less, and they should promote exports. The surplus countries should consume more, export less, and import more to achieve a balance.

But if you're looking at the whole global picture of imbalances, you have to think about complementarity issues. The world today is not evenly developed. Every country is at a different stage, with different strengths, different processes, different stages of production. For example, you see most advanced economies are service oriented, and emerging economies are manufacturing oriented, partly reflecting the division of labor. We see this in the persistent and concentrated imbalance that is the issue for the global economy. Both aspects, rebalancing and complementarity, will make the world more productive and more sustainable, and the IMF should play a central role in this process.

The IMF has a rich knowledge of the global economic situation and the financial sector. The IMF produces the World Economic Outlook, the Global Financial Stability Report, the Regional Economic Outlook: Asia and Pacific, and lots of other research. This helps economies in the region understand the rest of the world and become part of the policymaking process. There is much more the IMF can do in the region. So it needs to study Asia even more to further its links in the region.

FoD: How do you think the bigger role of Asia, and China, in the world economy should be reflected in the IMF?

$\mathrm{Zhu}$ : Most people's first response would be the quota and voice reform that is currently under way, to reflect the growing role of Asia and China. It's right to give China and Asia more status within the institution. But more important is for the IMF to understand Asia and China better and to bring Asia's and China's experience to the rest of the world.

Why is Asia so successful? Asia has its own experience and its own stories. There is a role for the IMF to play in bringing that experience to other emerging economies, and maybe to other advanced economies as well. Also, the IMF can and should bring Asia and China to the global platform to ask them to participate in the global policy formation process. 


\section{Deeper Markets, Cheaper Capital}

\section{Financial sector reforms can help reduce the cost of capital, spur investment, and promote rebalancing in Asia}

\author{
Sanjay Kalra
}

HE global debate on imbalances has placed "excess" savings in Asia under international scrutiny. Although the debate has centered mostly on the role of China, savings-investment balances in other countries, especially those of the Association of Southeast Asian Nations (ASEAN) including Indonesia, Malaysia, the Philippines, and Thailand, are also attracting attention.

So does Asia save too much or invest too little? The answer varies across economies: some need to reduce savings, while others need to increase investment. But what can be done to fix imbalances is relevant for most economies. Recent research (Kalra, 2010; Oura, 2008) suggests that investment in some Asian economies-specifically, spending by firms on capital investment-would be higher if financial sector reforms could reduce the cost of capital and allocate capital more efficiently. This would moderate imbalances.

\section{More robust systems}

Asian economies have so far weathered the onslaught of the latest global downturn with greater ease than in previous crises. Asian firms' finances have improved significantly since the 1997 crisis. Corporate leverage has declined, and profitability and liquidity have increased. Vulnerability indicators have also improved significantly, and default probabilities in the corporate sector are lower than a decade ago. In short, there is evidence of sounder corporate financing practices and strength in a number of Asian countries hit by the crisis. Financial systems in the region are also stronger. In particular, banking systems' financial indicators have improved over the past decade. So Asian economies can now increase investment spending to meet higher demand at home as they rebalance toward domestic sources of growth and make the most of the global upswing.

How Asian countries make use of these opportunities will depend, in part, on how well their financial systems can allocate investable funds across various investment projects, both by reducing the cost of capital and by directing funds to where they are needed most. Financial sector reforms can help with both.

\section{Room for expansion}

Financial systems in a number of Asian economies are still dominated by banks, with small local currency bond markets and little corporate bond issuance within those markets. Stock market capitalization is relatively low in many countries compared with advanced economies in Asia and beyond. Foreign participation in the equity and bond markets is also limited. Indeed, large movements in equity prices generated by periodic bouts of capital inflows are in part indicative of the limited depth and breadth of the stock market. All told, a number of Asian countries' financial systems need to grow and diversify.

Asian firms do substitute among alternative debt financing options and would actively seek alternatives to bank funding if capital markets were deeper and more liquid. For example, there was a large - but temporary-spurt in issuance of corporate securities in local currency debt markets in the midst of the global financial crisis in 2008. At the time, these firms' financing needs were arguably limited, and the issuance of corporate securities reflected a shift from bank financing to bond markets to take advantage of lower spreads (Kalra and Oner, 2010).

\section{Cost of business}

There is room for Asian financial systems to lower costs and allocate capital more efficiently. In some economies, including India, Indonesia, Malaysia, and Thailand, the cost of capital could be reduced further to levels in other banking systems in the region (Australia, Korea, New Zealand, and Singapore). Reductions in the cost of banking can be achieved through financial sector reforms to strengthen bank balance sheets, reduce nonperforming loans, and improve credit information. In addition, in countries such as Indonesia, structural reform that reduces credit risk-for example, through clearer collateral and bankruptcy procedures — would also help lower lending rates.

Cost measures of economies' banking systems are reflected in the overall cost of capital facing firms. Simple measures of the cost of capital make the point succinctly: countries with higher banking costs generally have higher cost of capital (see chart). 


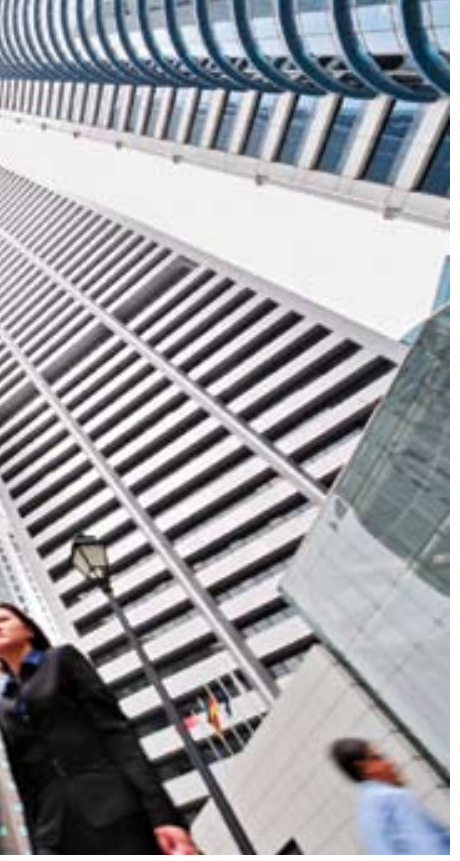

Since equity and corporate bond markets are relatively small in a number of Asian countries, the cost of credit from banks determines the cost of capital. These measures of the cost of capital—encompassing cost of equity and debt capital-are constructed in Kalra (2010) along the lines of Ameer (2007). These are comprehensive measures of the cost of capital, which incorporate countries' price-equity ratios, growth prospects, interest rate on debt, and corporate income tax rates.

And measures that reduce the cost of capital will, most likely, spur investment. Empirical analysis of firm-level capital spending suggests that financing costs are a key determinant of capital expenditures: a lower cost of capital is associated with higher capital spending by firms.

This holds for a range of economies in Asia-India, Indonesia, Korea, Malaysia, Taiwan Province of China, and Thailand - and for alternative sources of external financing of capital spending; that is, debt and equity. And capital spending is more sensitive to the cost of debt in some economies (Korea, Malaysia, and Taiwan Province of China), possibly reflecting higher stock market capitalization and significantly larger stock markets relative to gross domestic product.

\section{Efficient allocation}

Are there frictions in Asian financial markets-transaction costs that are high or make it difficult for firms to borrowthat reforms can resolve? Frictions can arise for a variety of reasons, such as institutional structure, financial market size, and information gaps. There is evidence that such frictions impede the efficient allocation of capital across sectors and firms in Asia.

\section{Cost of banking}

Some Asian banking systems can reduce their cost of doing business; those that do so are able to provide capital at lower cost.

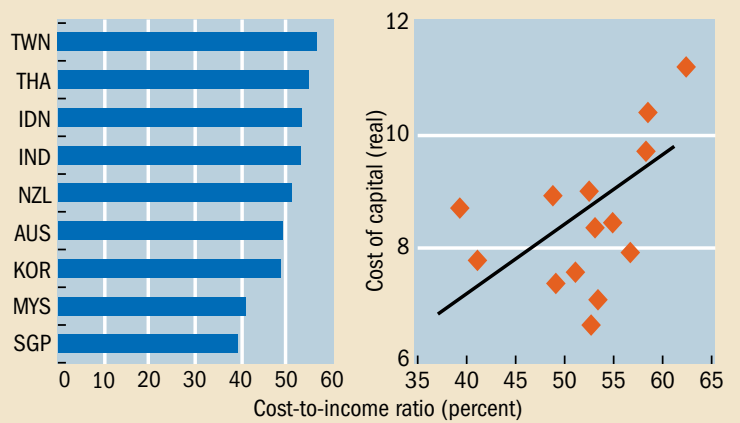

Sources: Bankscope; Worldscope; and IMF staff estimates.

Notes: TWN=Taiwan Province of China, THA=Thailand, IDN=Indonesia, IND=India, NZL=New Zealand, AUS=Australia, KOR=Korea, MYS=Malaysia, and SGP=Singapore.
Of course, friction and financing constraints differ across sectors and countries especially when compared with more developed markets such as the United States, so that the constraints to rebalancing most likely vary across economies. And there are also differences across segments of the financial system.

For some economies, such as India and Thailand, there is evidence of friction in the financial sector as a whole and of financing constraints on firms. Elsewhere, evidence of financial friction is weaker. In Korea, Malaysia, and Taiwan Province of China-which have deeper nonbanking segments-financial systems seem to allocate capital more efficiently. In particular, equity and debt markets appear to do a better job than banking systems of allocating funding across sectors and firms.

But that only works for exchange-listed firms that access external financing. However, many firms-mostly small and medium-sized enterprises that are not listed-in several countries are unable to access external financing through organized financial markets. For these firms, financing constraints remain acute. They rely heavily on internal sources to finance their growth. Financial sector reforms can be expected to ease financing constraints for unlisted firms.

\section{Reform measures}

Initiatives are already under way in Asian countries-at the national and international levels - to expand and reform financial systems. For example, Thailand has formulated its Financial Sector Master Plan II and Capital Markets Development Masterplan. Malaysia has recently adopted measures to further liberalize its financial sector and develop Islamic finance both in the banking sector and in capital markets. At the international level, the Asian Bond Market Initiative is an initiative of the ASEAN, China, Japan, and Korea (ASEAN+3) started in 2003. It aims to develop efficient and liquid bond markets in Asia, facilitating use of Asian savings for Asian investments. This initiative has made substantial headway in fostering local currency bond markets. And pan-Asian stock exchanges are being linked to improve the cross-border flow of capital in the ASEAN region.

Such reforms in Asia's financial markets will make them deeper and more efficient. This in turn will help reduce the cost of capital, spur investment, and promote rebalancing in Asia.

\section{Sanjay Kalra is a Deputy Division Chief in the IMF's Asia and Pacific Department.}

\section{References:}

Ameer, Rashid, 2007, "Time-Varying Cost of Equity Capital in Southeast Asian Countries," Asian Economic Journal, Vol. 21, No. 2, pp. 207-38.

Kalra, Sanjay, 2010, "Thailand: The Corporate Sector, Financial Reforms, and Rebalancing" (unpublished).

—, and Ceyda Oner, 2010, "Asian Local Currency Bond Markets: A New 'Spare Tire??” (unpublished).

Oura, Hiroko, 2008, "Financial Development and Growth in India: A Growing Tiger in a Cage?” IMF Working Paper 08/79 (Washington: International Monetary Fund). 
Perhaps India has the answer. The service sector has been one of the most dynamic parts of its economy, leading GDP growth for the past two decades. Unlike in other Asian economies, India's service sector productivity growth has tended to be higher than that in industry, thanks to:

- advances in communications technology, which gave India's ample supply of trained, English-speaking workers access to growing domestic and global markets;

- successful deregulation of services;

- privatization;

- foreign direct investment; and

- financial sector reforms.

\section{Unlocking growth potential}

Broad empirical studies suggest that deregulation and exposure to foreign competition could unlock the service sector's growth potential; improved access to financial services-especially for smaller firms, which often dominate key areas of the service sector, such as retail trade-could help alleviate resource constraints on growth. In Korea, for example, small and medium-sized enterprises account for 80 percent of service sector output.

In some cases, exchange rate appreciation would help shift resources to the nontradables sector by allowing a rise in their relative price. This in turn would reduce profit margins in the tradables sector and increase profit margins in the nontradables sector. Similarly, labor market reforms to facilitate hiring and firing workers as well as retraining incentives could help achieve smooth reallocation of resources. In many Asian econ-

Chart 1

Excess industry, low services

Most Asian countries' GDP is overly reliant on industry and less on services.

(percentage points: country share minus share of peer group)

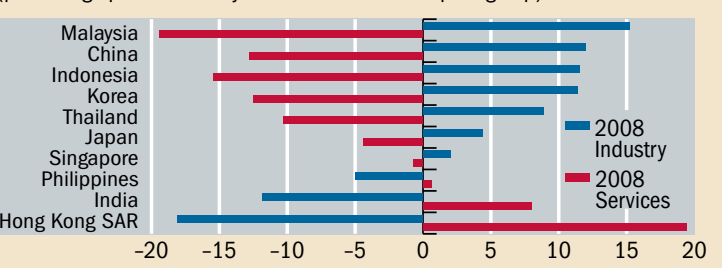

Sources: World Bank, World Development Indicators; and IMF staff calculations.

Note: Peer-group definitions are based on World Development Indicators. Countries were assigned the following peer groups: Hong Kong SAR, Korea, Japan, Singapore

(OECD); China, Indonesia, the Philippines, Thailand (low- and middle-income countries); India (lower-middle-income countries); Malaysia (upper-middle-income countries).

\section{Chart 2}

\section{Stagnating services}

Asia's services sector is a potential engine of growth.

(ratio of Asian productivity to U.S. productivity)

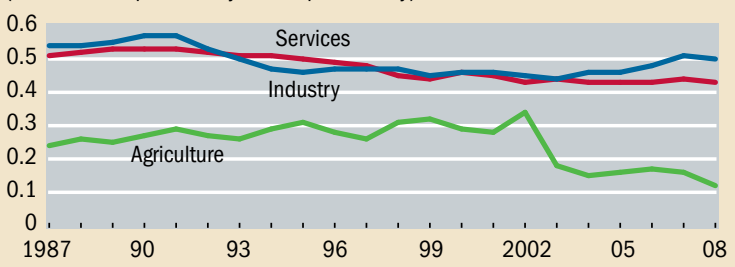

Sources: World Bank, World Development Indicators; and IMF staff estimates. omies, policies are already aimed at increasing competition in infrastructure-related services, opening up the retail and financial sectors, and lifting restrictions on foreign providers' entry into social services, such as health and education.

These reforms would benefit the service sector but also strengthen domestic demand. Since the Asian crisis, firm-level investment in the ASEAN economies has become more sensitive to the availability of internal funds. Firms find it hard to access bank loans and other external funds to finance investment. This problem is especially acute for small, domestically oriented firms operating in the service sector.

\section{Warming the investment climate}

Smaller and more service-oriented firms' access to financing could be strengthened by a shift toward more lending on riskbased terms; reforming collateral laws to allow businesses to secure loans with a wider range of assets than real estate and similar fixed assets; and widening the pool of venture capital funding through targeted tax breaks, as Malaysia has done. Deepening credit information and extending the coverage of credit registries (as introduced in the Philippines) through the 2008 establishment of the Credit Information Corporation has helped by improving banks' ability to assess credit risk. Reducing credit risk through a modernized corporate restructuring framework for small and medium-sized enterprises would also enhance access to financing.

The Korea Asset Management Corporation, for example, successfully created a market for distressed Korean corporate debt by purchasing nonperforming loans from banks and repackaging them for sale to investors. Similar companies could specialize in restructuring small firms' distressed debt.

Improvements in the overall investment or business climate are paving the way for more service sector-based growth in Asia. But even though the structural reforms implemented since the Asian crisis have made a substantive difference, perceptions have not yet caught up with the new reality. For example, indicators based on investor perceptions, such as governance-which worsened with the Asian financial crisis-still tend to lag those in advanced economies and exert a drag on investment activity. Asian economies need to continue increasing the competitiveness of their product and labor markets, as Hong Kong SAR has done with the adoption of a competition law; leveling the playing field for foreign investors, as Malaysia did recently when it lowered restrictions on foreign investment in the service sector; and ensuring contract enforcement and reducing administrative bottlenecksa step taken in Indonesia and Malaysia with their one-stop shops for foreign investors. Only with such measures will Asia be able to unlock its full growth potential-and will Asians like Nanancherla be able to put their faith in more than their people's capacity for hard work.

Olaf Unteroberdoerster is a Senior Economist in the IMF's Asia and Pacific Department. This article is based on the author's 2010 study with Adil Mohommad and Papa N'Diaye "Does Asia Need Rebalancing?" Chapter 3, Regional Economic Outlook: Asia and Pacific (April). 


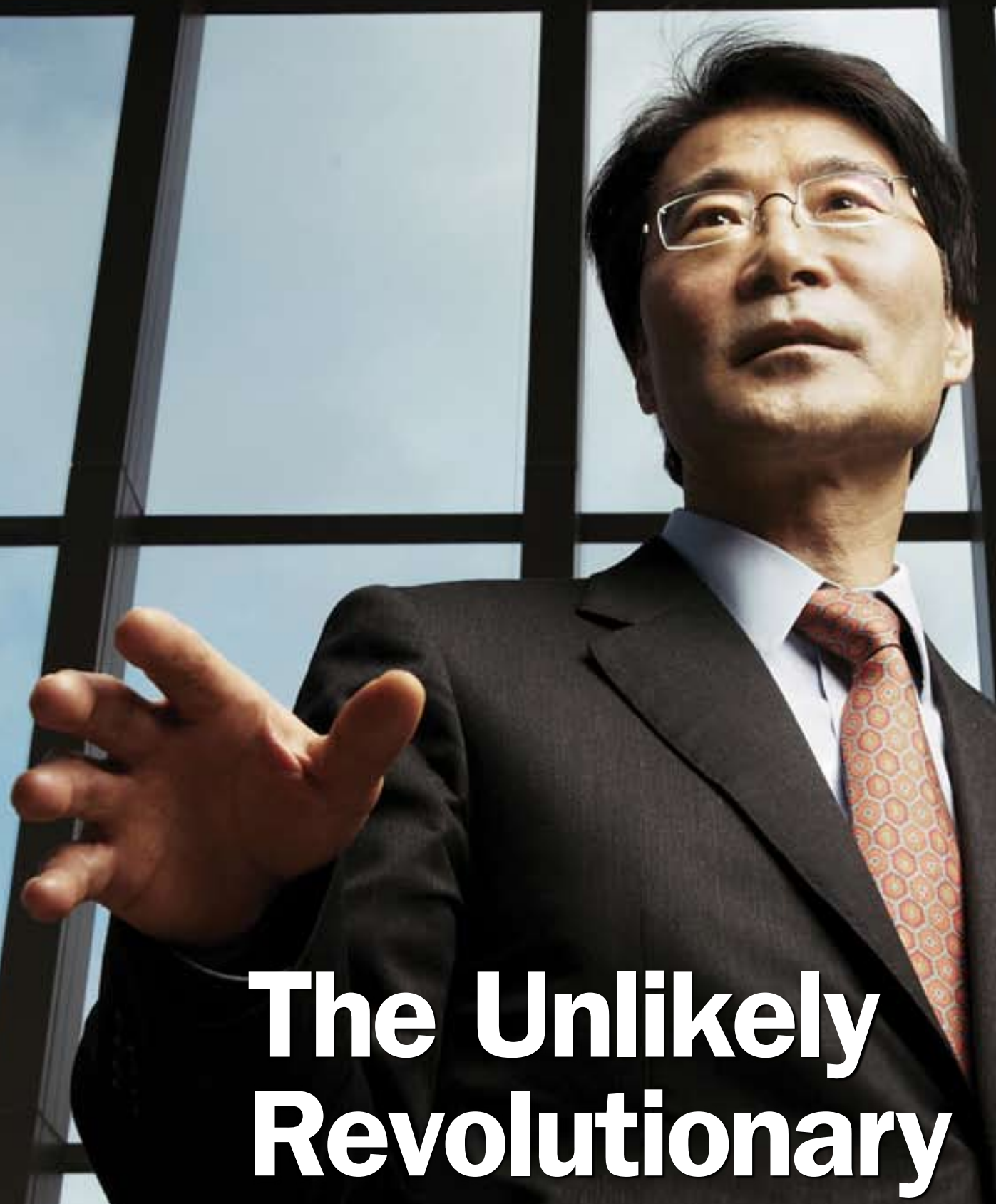

ANG HASUNG'S crusade against the opaque accounting practices of Korean big business was almost derailed in its infancy by a fainthearted young lawyer. In 1998, Jang and his

Hyun-Sung Khang profiles Korean crusader Jang Hasung

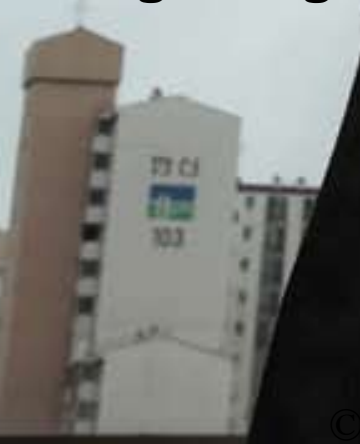
supporters filed a class action lawsuit against the Korean industrial powerhouse Samsung Electronics, accusing it of making illegal political donations and unlawful subsidies to a failing subsidiary. With limited funds, Jang was forced to use the services of a fellow activist - a recently minted young lawyer - to champion his cause. Samsung, for its part, had hired the best: "the king of litigation," as he was known in local legal circles. So, in a strongly Confucian culture in which seniority automatically confers additional authority, the plaintiff's young counsel faced the disadvantage of both youth and inexperience. 
After the first hearing, the young lawyer approached Jang in despair and said, "This is an impossible game. The judges and other lawyers treat me like a child." Jang, now dean of the business school at one of the country's most prestigious education establishments, Korea University, laughs at the memory: "Such a huge imbalance!" he recalls, but then suddenly turns serious. Confronting defeatism before the case had even been heard, "I told him, 'Look! You do it for the cause-justice. He does it for the money. That's a huge difference. You have commitment. He just has incentive. So don't worry."

Jang and his counsel went on to win that case: one of Korea's first-ever lawsuits on behalf of minority shareholders against the directors of the industrial giant. The ruling marked a milestone in Korean corporate legal history. And the young attorney? "His name is in the law books now," says Jang.

The same conviction and optimism Jang exhibited in 1998 have sustained him over more than a decade of campaigning for shareholder rights and better corporate governance when he faced threats to his safety, the loss of friends alienated by his activism, and accusations of selling out to foreigners.

\section{The path to activism}

Jang, 56, is an unlikely revolutionary, and his life could have been very different. After earning a Ph.D. in finance from the Wharton School of Business at the University of Pennsylvania, he could have disappeared into academic obscurity or a secure job for life at one of Korea's leading industrial groups - the targets of his later activism. But on his return from the United States, he discovered a major lesson he had learned from his studies - that the primary aim of firms to increase value for their shareholders-did not, in his view, hold true for the giant industrial conglomerates that dominated Korea's economy. Instead, these "chaebol" (see box) were run as personal fiefdoms by the company's founders, without transparency or accountability.

"Everything was centered on one controlling person, whom they called 'chairman'; sometimes they called him 'owner.' But if you look at the ownership structure, he is not the owner. He's only a small, small minority shareholder, and that applied to most of the chaebol," says Jang. "Where does his uncontested power come from? And why the abuse of this controlling power for his private benefit? [At the time] no one was raising the issue," he recalls.

So Jang launched a crusade for greater accountability and transparency in the giant family-run conglomerates, which still dominate much of Korea's economy. The action was organized under the auspices of a grassroots civic group Jang helped found-People's Solidarity for Participatory Democracy (PSPD) - which is now one of the country's leading nongovernmental organizations. Their weapon of choice: the class action minority shareholder lawsuit. The PSPD pushed for the appointment of outside directors, forced light onto opaque accounting practices, and demanded consideration for shareholders' interests.

At the beginning of his activism, Jang describes himself as a "gadfly" on the elephantine body of the chaebol. The notion of shareholder rights barely existed in Korea at the time, nor was there an adequate translation of the term "corporate governance." The law-which then required shareholders to own 5 percent of a company before bringing a motion to a shareholders meeting - created a huge barrier to challenging the might of the chaebol. The firms dismissed his early attempts to hold them accountable. A struggle with Korea First Bank stalled when the bank refused him access to board minutes, company papers, and shareholder registers. Unable to identify the atomized equity holders, Jang and his supporters took to the streets. Armed with placards, they marched in front of brokerage houses, calling on shareholders to make contact.

Jang's campaign baffled many of his friends, relatives, and peers. In Korea's close-knit society, many of them worked in the very companies he was challenging, and they pressured him to stop his rabble-rousing. He was branded antibusiness, anti-Korean, perhaps even communist-an accusation guaranteed to provoke suspicion and scorn.

\section{Market believer}

Far from being a communist, Jang holds an unconditional faith in markets, which he combines with a desire to promote the public good. "I love to make money," he says. "There is nothing wrong with making money in a market system. If everyone involved is making money-shareholder, employees, society-and we make the company better and make society better, it's a win-win-win game."

The promotion of the public good may be a central motivation for Jang, but it is stripped of any ethical or moral language. Rather, his indignation lies in his belief that corruption in Korean firms is preventing market forces from functioning properly. Jang's colleague John Lee describes the crusader as a "Western-style capitalist." Lee says of his friend, "His view is that money is a driving force for change. It is not a justice kind of thing. It's a belief that companies should make money and that the chairman should make money for the company."

Jang has also benefited from being the right person in the right place at the right time. Certainly, the Asian financial crisis of 1997-98 came at the right time for Jang's campaign. As his activism was taking off, the crisis shone an unprecedented spotlight on the accounting and management practices of the country's chaebol and their role in precipitating the worst downturn in Korea's modern history. It focused attention on the tangled web of cross holdings between the chaebol's parent company and its subsidiaries, used to hide the unsustainability of subsidiaries and protect them from hostile takeovers. These subsidies and murky cross holdings had also given rise to unsustainable debt and conflicts of interest.

At the depth of the Asian slump, Jang targeted a plan by Samsung Electronics to provide debt guarantees to its ailing car manufacturing subsidiary. It was one issue of many that he and his followers wanted to raise during Samsung Electronics' annual meeting in 1998-an event that has attained near totemic status among Korean civic activists involved in corporate governance. On that day, for more than 13 hours Jang and his supporters heckled and interrogated 
company directors more used to shareholder meetings as a rubber-stamping forum. The activists failed to resolve the Samsung Motors problem on that occasion, but Jang's wider actions and those of the PSPD triggered the beginnings of a move by some of Korea's family-run chaebol, such as SK Group and LG, to start separating their holding companies from their operating units.

Inevitably there have been setbacks: defeat in the courts, public incomprehension, and charges that the activists were undermining confidence in the Korean economy. But the gains of Jang and his supporters have been as much about changing corporate norms and public education as legal victories and defeats. The Asian crisis also helped precipitate the change in public opinion-many who had looked askance at Jang came to the slow realization that the chaebol must change or be forced to change. The liberal administration of Kim Dae-jung, voted into office in the early days of the crisis, embraced a swathe of corporate reforms, which continued under a second left-of-center administration. Those reforms included lowering the threshold to bring a motion to a shareholders meeting to 1 percent of shareholders then to 0.01 percent, establishing a requirement that one-quarter of directors be appointed from outside the company, a new securities law favoring minority shareholders, and tighter rules on disclosure, accounting, and board selection.

\section{A history of fight}

Given Jang's background, it is perhaps unsurprising he has fire in his belly. His family roots lie in the southern city of Kwanju-well known in Korea for its history of protest. One close family member died in the landmark 1980 mass demonstrations in his hometown against the military dictatorship of the time. The academic boasts an impressive pedigree. During Japanese colonization, his grandfather fought for Korean independence, while his grandfather's brother was involved in the military campaign against Japanese rule. As well as being a scion of a wealthy and well-educated family_ - "all his family members are Ph.D.s," a friend jokes-public service also runs in the family. An uncle and sister have held high government office, and he shoulders the responsibility conferred in Confucian culture on the eldest son.

Jang's own declared battle for the public good has transformed him from a protester on the sidelines to a respected public figure. But that growing respect again took a beating as he turned his fire away from the chaebol toward small and medium-sized companies. Jang credits the shift in his focus to an exchange with a European financier who spoke to him in a language they both understand-that of the market. The financier, whom Jang does not identify, told his Korean friend: "You seem to have a strategy to capitalize on undervalued assets. There are clearly assets [in Korea] which are mispriced,

\section{The Republic of Chaebol}

A Korean could spend an entire day living in the world of Samsung. In the morning, he might leave his Samsungconstructed apartment and drive to the office in his Samsung (Renault)-manufactured car while speaking on his Samsung cell phone. He might purchase lunch from a Samsung-owned department store and eat food produced and distributed by Samsung (Cheil Jedang), heated up in his Samsung-produced microwave while watching his Samsung television.

Such is the penetration of the chaebol in Korea that few aspects of life in this northeast Asian country have been left untouched by the sprawling influence of Korea's giant, familyfounded corporations. The Samsung Group is just the largest and most powerful of them, accounting for about 20 percent of Korea's gross domestic product, earning it the moniker "the Republic of Samsung."

The chaebol are the channel for Korea's rapid economic development. Under the military dictatorship of Park Chunghee in the 1970s and 1980s, the government provided the blueprint for industrial expansion; the chaebol carried it out. Under this system of guided capitalism, the government selected companies for industrial projects, fueled by low-interest loans from state-controlled banks. The reach of chaebol grew to include a broad range of industrial and service businesses protected from foreign competition and enjoying implicit government risk sharing and guarantees. Economically profitable activities wound up in the hands of a limited number of conglomerates.

Chaebol's highly centralized, autocratic management systems revolved around powerful founding chairmen and their immediate family members. The fate of these chaebol fami-

lies - the nearest thing Korea has to royalty-is a source of endless public fascination. In several cases, the mantle of chairman is now being passed down to a third generation. The founding chairman's family typically maintains control of the business through cross ownership, even though its economic stake in the major group companies may have dwindled over time to less than 10 percent in many cases.

By the late 1980s, chaebol dominated Korea's industrial sector and were especially prevalent in manufacturing, trading, and heavy industry. They had started making strides into global markets, financed through cheap government credit and excessive leveraging. In 1997, on the eve of the Asian financial crisis, the debt-to-equity ratio of the top 30 chaebol exceeded 530 percent, often on short-term loans.

But that level of debt proved too much for many of them. The crisis heralded the demise of about half of the top 30 conglomerates. The surviving firms have drastically reduced their overall short-term and long-term debt financing, and, among the top 30 groups, new intragroup guarantees are no longer permitted and existing ones have been eliminated.

Koreans are deeply ambivalent about these homespun engines of growth. The egalitarian instincts of Koreans mean they have a deep suspicion of the controlling family's accumulation of wealth, but they also remain proud of the global success of the chaebol. They recognize that the fate of the country's export-driven economy hinges on the fate of the giant conglomerates - to such an extent that threats to rein in their influence and power are regularly met with warnings of dire consequences for the economy. 
undervalued, and which are never capitalized. One of those undervalued assets is you." The financier challenged Jang to put his money where his mouth was and enter the private sector. "In this capitalistic market, unless you make money and show results, there is no persuasion power," he told the academic.

The seed was planted, but again Jang benefited from the fortuitous collision of right man, time, and place. While Jang was marching outside brokerage houses and appealing to small shareholders to come forward, he caught the attention of Lee, then an asset manager working in the United States. Intrigued by the activist, Lee made contact, and their friendship ensued. Lee supported Jang's campaign by delegating his voting rights to Samsung to give the campaigner a voice at shareholder meetings.

\section{Making up the discount}

A decade or so later, Lee, then with Lazard Asset Management, helped launch the company's Korea Corporate Governance Fund (KCGF) with an initial capitalization of about $\$ 35$ million, according to Jang, who was recruited as its special advisor. That capitalization has now increased, he says, to $\$ 250$ million, and so great is his brand recognition that the fund is known locally as the Jang Hasung fund. Its mandate: to unlock the value of small and medium-sized companies by improving the quality of their corporate governance and reversing the traditional undervaluation of Korean stocks, commonly described as the "Korea discount."

Korean stocks are widely thought to trade below their true value because of the higher risk investors assume to enter the country's stock market. This is frequently illustrated by the low price-earnings ratios of Korean stocks, compared with those in other markets. The discount is attributed to factors ranging from the risk posed by neighboring nuclear North Korea, to overleveraging at firms, to inefficiencies in the market. Jang thinks poor corporate governance is largely responsible. Improve a firm's governance, do away with the discount, and you reap benefit from the increased value of the company, his thinking goes.

KCGF's first investment was a 5.1 percent stake in a small textile company, Daehan Synthetic Fiber. The purchase was soon followed by demands that the company appoint outside directors, sell idle assets, and disclose transactions with affiliates. The fund requested access to the firm's shareholder register six times, and six times the firm refused. Finally, a court order forced the firm to capitulate.

Once labeled antibusiness, ironically, Jang's involvement with KCGF has forced him to deny accusations of profiteering. Jang protests, saying that he is committed to increasing the value of companies for the long term, even though the price of a company's stock can soar on the simple announcement of a share purchase by KCGF. Minutes after news of the purchase of Daehan equity, stocks in its parent company, Taekwang Industrial, hit their permitted daily ceiling, while the price of Daehan shares doubled in five days. Jang chalks up the rise to herd behavior. "In the space of a few minutes, what changes do you think we could make? Nothing changed on the company side. We only said, 'OK, we will work with the company.' Yesterday, today-it's the same company. It will take a number of days, months, even years to bring even a slight change."

In KCGF's short history, change has already involved considerable litigation as well as accusations of hostile and aggressive involvement in the operations of companies in which the fund buys shares. And despite the involvement, there is no guarantee of success. After buying shares in a local construction material firm, Byucksan, KCGF lost a shareholder vote and, against its wishes, saw the reinstatement of the chairman and auditor. KCGF later sold its holdings in the firm. "We gave up," says Jang. "There are companies where we want to bring changes and use all the weapons, including criminal cases or civil cases or any way we can that the law allows us. But by doing that, sometimes it destroys the value."

\section{Jang is committed to increasing the value of companies for the long term.}

The chaebol and the Korean business establishment have often charged Jang with being a conduit for opportunistic foreign predators more interested in making a quick profit than in corporate reform. Ninety-five percent of KCGF's investors are from overseas, but Jang says he deliberately avoids marketing the fund to local institutions, because their investment horizon is too short to allow him to meet the fund's objectives. Whereas investors in the West often look to accrue value over years, in Korea the average holding time for an institutional investor is months. "They would call me every week, every month, asking about profits," he says. For local investors Jang has this message: "If you are not patient enough, don't follow me, because over the short term nothing will change. It will take days, months, perhaps years."

Patience is a quality Jang has been forced to develop throughout his career as a crusader. Legal cases brought by Jang and his supporters have dragged on through numerous appeals and counterappeals, many lasting years. The original class action that Jang, his young lawyer, and the PSPD filed in 1998 against Samsung Electronics was not decided until 2001 by the district court, which awarded them damages of more than $\$ 72$ million. Two years later, the court of appeals concurred with the lower court, but reduced the award to $\$ 16$ million. Both the PSPD and Samsung appealed and the case went to the Supreme Court. The highest tribunal in the land backed the original decision and found in favor of Jang and his allies. The Supreme Court ruling in 2005 came seven years after the filing of the original suit. In this instance at least, Jang's conviction and optimism had finally paid off.

Hyun-Sung Khang is a Senior Editor on the staff of Finance \& Development. 


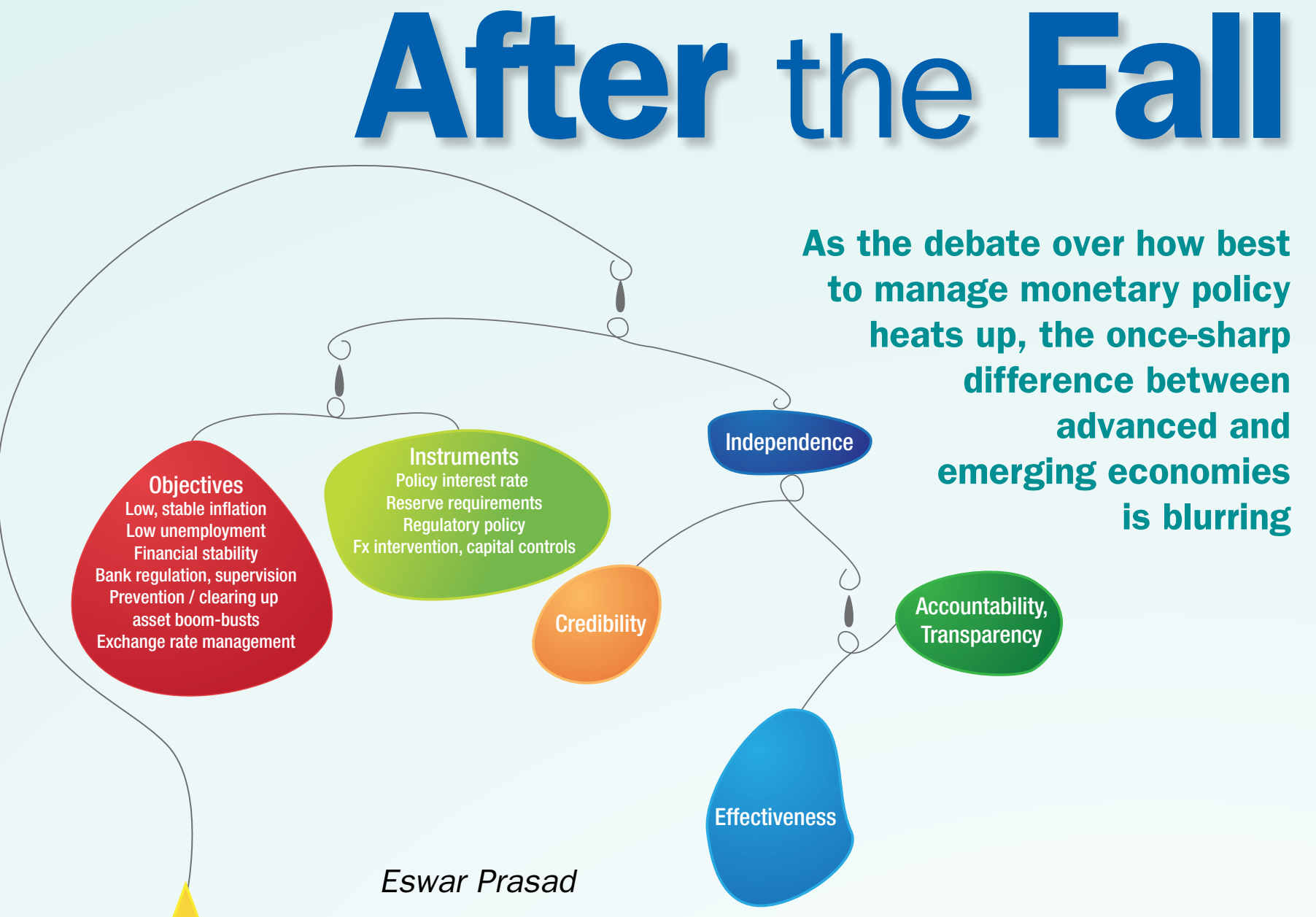

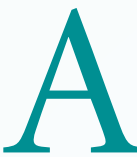
$S$ the world economy ponders the lessons from the receding global crisis, a fierce debate has erupted about central banking concepts thought to have been long settled (Goodfriend, 2007). The appropriate role and mandate of central banks has come under scrutiny around the world.

Globalization has made both advanced and emerging market economies more exposed to external shocks, as their rising openness to trade and financial flows creates wider channels for cross-country spillovers of shocks. These forces have also increased the burden on monetary policy. It is much harder now for a central bank to use instruments such as interest rate changes to attain domestic objectives; as capital sloshes around the globe it can create many difficulties in managing monetary policy, especially in economies with shallow financial systems. And yet, monetary policy is gaining importance as a first line of defense against external shocks and breakdowns in the financial system, because it can be far more nimble than other macroeconomic policy tools.

This has generated a rich debate: what the right framework is for monetary policy, what the scope of a central bank's objectives should be, and what the optimal degree of central bank independence is. Even as clarity about optimal monetary frameworks has diminished, a remarkable outcome of the crisis has been a convergence in the nature of the debates about central banking in economies at different stages of economic and institutional development.

Emerging market central banks have been considered as lagging behind those in advanced economies-in terms of the rigor of their operating frameworks and also their sophistication and transparency. But central banks in emerging markets have come out of the crisis looking a lot better than their advanced economy counterparts. Lesssophisticated financial markets and much greater regulatory prudence proved to be an advantage. Consequently, some interest- 
ing twists have come up in the debates about suitable monetary and regulatory policies for emerging markets (Gill, Kanbur, and Prasad, 2009). At the outset, it is worth reviewing some general principles that are relevant for all types of economies.

\section{Targeting inflation targeting}

Over the past two decades, inflation targeting-in either explicit or implicit form-has become the monetary policy framework of choice for most advanced economies. A number of emerging market central banks have also adopted frameworks in which their priority is to maintain inflation at a target level or within a specified range. Many others had been moving toward such a system. Inflation targeting has had a good track record of delivering price stability and anchoring inflation expectations, which has proven valuable in emerging markets, where high inflation is especially pernicious because it hits the poor disproportionately hard.

But inflation targeting has come under sharp attack in the aftermath of the global financial crisis. Central bankers in developed economies are being pilloried for focusing too much on price stability, ignoring asset market bubbles, and failing to prevent the worst crisis seen for a generation.

Meanwhile, although many emerging markets weathered the crisis relatively well, central banks in that group that target inflation also face pressure to abandon the framework. Critics argue that targeting inflation could be damaging to these economies if it means disregarding sharp exchange rate fluctuations and boom-bust cycles in equity and housing markets.

Indeed, a more sweeping argument by some emerging market central bankers is that low inflation is neither necessary nor sufficient for financial stability. That enormous financial market stresses built up in many advanced economies during a time of low inflation and stable growth forces one to take this view seriously.

\section{Asset market bubbles}

Price bubbles in housing and equity markets can have destructive effects on financial markets and the economy when they pop, as they eventually do. This reality seems to legitimize the argument that central banks cannot ignore asset price bubbles and that a narrow framework that restricts central banks from taking preemptive actions against bubbles is doomed to failure. But there is a major problem-it is difficult to detect such bubbles in real time and far from obvious that monetary policy is the right tool to prick these bubbles before they become large.

The purist view on monetary policy is that as long as central bankers have the right macroeconomic model for inflation, asset bubbles should be incorporated into the inflation-targeting framework. Asset booms increase the financial wealth of households and firms, causing them to feel richer and spend more. That should translate into rising aggregate demand that would increase inflation that in turn would trigger a policy response. In other words, central banks would automatically head off asset bubbles by taking monetary policy actions to counter their inflationary impact.
Yet, even if central banks had the right model, asset prices could boom rapidly and cause destructive busts before their aggregate demand implications became apparent.

A compromise position is that bubbles fueled by loose monetary policy_perhaps, for example, the housing boom in the United States - should be brought to heel by monetary policy, while others-such as the equity price boom in the technology sector in the early 2000s-should be dealt with using regulatory policies or be allowed to run their course. This approach faces its own set of problems because of the difficulty in detecting and heading off bubbles, let alone divining their causes. Even now it remains a matter of contention whether the proximate cause of the housing boom and subsequent bust in the United States was lax monetary policy or weak regulation.

However this debate is resolved, in the aftermath of the crisis it will be difficult for central banks to ignore asset prices, even if they do not target them in any formal way. Indeed, an explicit financial stability mandate will require central banks to manage asset prices. After all, in the recent crisis, the fall in U.S. house prices ultimately brought the entire financial system to its knees. Some central bankers even contend that preserving financial stability is so closely related to the standard goals of monetary policy that it is impossible to separate the two functions (Blinder, 2010).

This aspect of "mandate creep" for central banks could create complications. Consider the notion of using regulatory tools to manage asset bubbles and ensure financial stability, while using interest rate policy to manage inflation. This can create tension when the financial well-being of the financial institutions for which the central bank is responsible might be affected by interest rate policy. For instance, low policy interest rates are good for bank profits because they give banks access to cheap money, but low rates could cause a surge in inflation expectations and fuel asset price bubbles.

There is a bigger risk to this particular aspect of mandate creep. Although it is tempting to include asset prices in the monetary policy framework, it is dangerous to ask central banks to manage asset market outcomes without clear criteria and without knowing how monetary policy actions influence asset prices. These are uncharted waters, but the practice of central banking clearly cannot be put on hold pending a theoretical resolution of these issues.

\section{Objectives and instruments}

In the midst of a crisis, monetary policy has to be pragmatic and use all available tools. Indeed, the decisive and massive liquidity interventions by central banks around the world played an important role in keeping financial systems from imploding during the recent crisis. This still leaves open the question of which monetary policy framework is right for more normal times. Which framework will contribute to macroeconomic and financial stability, reduce business cycle fluctuations, and create room for monetary policy to respond aggressively to adverse external shocks?

The conventional view, grounded in academic work and practical experience, is that monetary policy effectively has 
a single instrument-usually the policy interest rate-and that this can at most be used to attain one objective, such as low and stable inflation. A more nuanced version is that most central banks in fact have two instruments-a monetary policy instrument and regulatory authority. The former should be used to manage inflation, while the latter prevents imbalances from building up in the financial system. But even this limited set of objectives creates tensions. For instance, as already noted, what is good for the financial system in times of stress-low interest rates and abundant liquidity-may not always be good for managing inflation outcomes.

Such tensions are heightened in emerging markets, where central banks have traditionally been responsible for a broad array of social and economic goals in addition to price and financial stability. For instance, the mantra that a stable and transparent monetary policy focused mainly on one objective is best in the long run comes up against the harsh practical reality that surges in capital inflows and the resulting exchange rate appreciation can have permanent pernicious consequences for export-market shares and hurt the central bank's legitimacy. As a result, ancillary objectives such as exchange rate management already complicate the conduct of monetary policy in these economies. Instruments such as capital controls have limited effectiveness and create problems of their own.

A different perspective is that, in emerging markets, central banks ultimately end up being held responsible for a large set of objectives. One option is to try to embrace all these objectives, with all the risks that entails, because the alternative is to be blamed in any event if something goes wrong with any of those objectives. On the other hand, it can be equally argued that facing multiple objectives makes it more essential for a central bank to set and communicate a more limited set of goals that it can hope to deliver effectively.

If a central bank does take on multiple mandates, it can create unrealistic expectations about what it can and cannot do with the tools at its disposal. Indeed, there is a temptation to ascribe omnipotence to monetary policy, an attribute that some emerging market central bankers find forced on them. But this burden may be too much to bear and doomed to eventual failure, especially in economies with weak institutional structures, limited regulatory capacity, and high levels of fiscal deficits and public debt. Even in the absence of these constraints, monetary policy by itself cannot influence an economy's long-term growth potential or shift the unemployment rate for an extended period.

A more circumscribed view is that monetary policy can best contribute to macroeconomic and financial stability by maintaining low and stable inflation. This framework, if it operates well, defines the limits of monetary policy and provides a clear standard of accountability. The tensions among these varying perspectives feed into the debate about central bank independence.

\section{Does independence matter?}

Central bank independence is under assault around the world. In the United States, Congress is threatening to put the Feder- al Reserve Board under tighter surveillance even while giving it a broader mandate to manage large and systemically important financial institutions. In other countries, the crisis has served as cover for politicians to try to rein in central banks. In Argentina, the President fired the central bank president for not agreeing to use foreign exchange reserves to pay part of the country's debt obligations.

These developments are taking place against the prevailing notion that central bank independence is an unalloyed virtue because it allows the institution to focus on what it does best, without political or other constraints, and helps build credibility for the central bank in managing inflation expectations. This credibility comes in handy during tough times because it gives the central bank room to employ extraordinary measures without inflation expectations getting out of hand. An example is the relatively modest inflation expectations in the United States, despite the massive amount of liquidity injected by the Federal Reserve during 2008-09 and the rapidly rising level of public debt. At least so far, markets seem convinced that the Fed will not let inflation get out of hand.

The concept of central bank independence is complex, however. The conventional notion is that an independent central bank with a narrow but well-defined objective such as maintaining low and stable inflation has the best chance of being effective and transparent, making it less subject to political interference. Even central banks that have a clearly defined single objective in the form of an inflation target have only operational independence to achieve that target. The government determines the target itself and the consequences of missing it. Indeed, if the government was not involved in setting it, the target would lack broader public legitimacy.

Even such a narrow objective could be difficult to deliver if the government runs a profligate fiscal policy, racking up large budget deficits. Furthermore, if central banks are made responsible for financial market stability and avoidance of asset price bubbles, they must be given more instruments than a policy interest rate (or, in some cases, a reserve requirement). There is however, deep tension between central banks having multiple objectives-even if they have a corresponding number of instruments - and the operational independence needed to achieve the inflation target. Broader objectives invariably mean more political interference and reduced credibility in maintaining low inflation.

These complications are heightened in emerging markets. In many of these economies, central banks are among the most well-managed and trusted public institutions, which makes it tempting to give them more responsibilities. But taking on more responsibilities could make them less effective at the one thing they have proven good at-controlling inflation.

The real conundrum is that a narrower set of objectives could also result in central bank independence being threatened if it looks as if the central bank is not concerned about other objectives such as growth and employment. Central bankers in some emerging markets implicitly argue that what little independence they have already hangs by a thread, 
which could be severed if, for instance, the central bank does nothing about rapid exchange rate appreciation that hurts exporters or asset bubbles that can inflict considerable pain when they pop.

The classic retort is that the central bank can best contribute to high growth and financial stability by providing a stable macroeconomic environment through price stability. Given developments during the recent crisis, this argument has come to sound dogmatic and almost untenable. Indeed, this is one area where there seems to be a rising disconnect between the theory of central banking and its practice.

\section{Many alternatives}

Despite the rising prominence of inflation targeting, there remains a wide range of alternatives in the practice of central banking. At one end of the spectrum are formal inflationtargeting central banks such as those in Canada, New Zealand, and Thailand. The U.S. Federal Reserve has a formal dual mandate of fostering growth and price stability, but is widely seen as having an inflation objective as its main priority. At the other end of the spectrum is the Reserve Bank of India, whose Governor, Duvvuri Subbarao, explicitly bills it as a full-service central bank that has multiple objectives-with low and stable inflation not necessarily the dominant priority. A number of central banks, including the People's Bank of China, have one form or another of an exchange rate target, effectively importing monetary policy from abroad.

Theoretical models have had a much narrower range. For instance, models of inflation-targeting frameworks have focused largely on strict targeting or a flexible form that has the central bank putting some weight on the output gap, which measures the degree of slack in an economy. There is little research making explicit connections between price stability and financial stability or indicating how asset prices might be incorporated into a broader monetary framework.

Even in a narrow context, academic research is only beginning to grapple with the particular challenges facing emerging markets. For instance, the question of which price index an inflation-targeting central bank should aim at takes on a very different hue in low- and middle-income economies. In these economies, food expenditures account for nearly half of total household expenditures, and a large proportion of the population works in a cash economy with little access to the formal financial system (Anand and Prasad, forthcoming). It is untenable for central banks in these economies to target just core inflation, which excludes volatile food and energy prices-even though classical theoretical models suggest core inflation is the proper target. Broader questions about the right level of inflation that should be targeted in emerging markets or the trade-offs between higher inflation and stronger currency exchange rates also remain unresolved (Blanchard, Dell'Ariccia, and Mauro, 2010).

The net result is that, even as academics (including the author) call for more robust monetary policy frameworks that are better grounded in analysis, they have not provided frameworks that come close to dealing with the complex practical challenges that emerging market central bankers face.

\section{Keeping things normal}

Central bankers have shown their ability to respond effectively to crises. The core issue is not crisis response, however, but rather which monetary policy framework will reduce the probability of crises in the first place. Here the answers are less clear. Interestingly, virtually every economy that had an explicit—or implicit—inflation-targeting regime in place before the crisis has more or less indicated its intention to stick with that framework, perhaps because it has a good record of delivering price stability.

A number of questions remain about how inflation targeting can be adapted to the postcrisis world. A more fundamental issue, though, is whether the approach even provides a baseline framework that can be adapted to the circumstances of specific countries.

Is inflation targeting a framework that liberates central banks to do what they can do effectively and set realistic expectations for what monetary policy can achieve? Or is it a straitjacket that causes central banks to ignore financial market and macroeconomic developments that ultimately can pose big risks?

Pragmatism is an excellent operating rule in desperate times, but does not provide a framework for stability in normal times. Operating without a framework offers flexibility and adaptability, but at the cost of weakening the anchor for inflation expectations. It also risks limiting central banks' ability to build up credibility that could come in handy in times of macroeconomic and financial stress.

Inflation targeting still seems the most defensible framework, and blaming it for regulatory failures that caused a near financial collapse may result in throwing out the bathtub, along with the baby and the bathwater. Striking a balance between these perspectives will not be easy. Central bankers and academics alike have some hard thinking ahead of them.

\section{Eswar Prasad is the Nandlal P. Tolani Senior Professor of Trade Policy at Cornell University, the New Century Chair in International Economics at the Brookings Institution, and a Research Associate at the National Bureau of Economic Research.}

\footnotetext{
References:

Anand, Rahul, and Eswar Prasad, forthcoming, "Optimal Price Indexes for Targeting Inflation under Incomplete Markets," National Bureau of Economic Research working paper.

Blanchard, Olivier, Giovanni Dell'Ariccia, and Paolo Mauro, 2010,

“Rethinking Macroeconomic Policy," IMF Staff Position Note 10/03

(Washington: International Monetary Fund).

Blinder, Alan, 2010, "How Central Should the Central Bank Be?"

Journal of Economic Literature, Vol. 48, No. 1, pp. 123-33.

Gill, Hammond, Ravi Kanbur, and Eswar Prasad, eds., 2009, Monetary

Policy Frameworks for Emerging Market Economies (Cheltenham, United

Kingdom: Edward Elgar Press).

Goodfriend, Marvin, 2007, "How the World Achieved Consensus on Monetary Policy," Journal of Economic Perspectives, Vol. 21, No. 4, pp. 47-68.
} 


\title{
Redefining Central Banking
}

\section{Central banks must distill lessons from the global crisis and make concrete reforms}

\author{
Duvvuri Subbarao
}

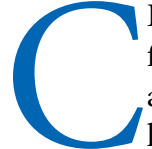

ENTRAL banks have been at the heart of the global financial crisis. They have been blamed for policies and actions that got the world into the crisis; they have been praised for leading the world out of it. Both are fair assessments. Central banks have been a part of the problem and a part of the solution.

As the crisis unwinds and recovery takes hold, central banks face a number of issues, of which I will address five.

\section{Monetary policy in a globalizing environment}

The crisis has demonstrated the difficulties of macroeconomic management in a globalizing world. Even as governments and central banks acted with an unusual show of policy force, they were unable to get the situation under control because of the interconnectedness of the financial system and the effects, positive and negative, of external developments on domestic policy actions. Most important, they found that sentiment and confidence were remarkably correlated across countries.

External developments interact with the domestic economy in complex, uncertain, and even capricious ways. Central banks have to deepen their understanding of these interactions. Some of the channels through which cross-border transmission occurs are quite familiar-global prices, including commodity price movements; synchronization of business cycles; capital flows; strong comovement of asset prices; exchange rates of key international currencies; and interest rate policies of major central banks. Some of the transmission channels are less familiar. For example, the crisis has shown that even differences in regulatory regimes can trigger arbitrage-based action and dilute the efficiency of domestic policies.

Take managing capital flows. Emerging market economies experienced a sudden stop in capital inflows during the crisis as well as capital outflows-the result of global deleveraging. Now the situation has reversed and many emerging market economies again have net inflows. Managing these flows, especially if they are volatile, will test the effectiveness of central bank policies in semi-open emerging market economies. A country whose central bank does not intervene in the foreign exchange market will incur the cost of currency appreciation unrelated to fundamentals. If central banks intervene to prevent appreciation, they will have to contend with additional liquidity and potential inflation pressures. If they sterilize (soak up) the resulting liquidity, they run the risk of driving up interest rates, which would hurt growth prospects.

Volatility in capital flows could also impair financial stability. How emerging market economies manage the impossible trinity of an open capital account, a fixed exchange rate, and an independent monetary policy will affect their prospects for growth and price and financial stability.

\section{Redefining the mandate of central banks}

The crisis has triggered vigorous and wide-ranging debate on the role and responsibilities of central banks and raises three big questions:

Should central banks persist with inflation targeting? In the years before the crisis there was a powerful intellectual consensus in favor of inflation targeting - that is, basing monetary policy on achieving a target inflation rate, usually consumer prices. Even where central banks did not target a

\section{Central banks' efforts to check}

\section{asset price bubbles demand not just analytical capability but mature judgment of the nature of the risk.}

precise inflation rate, their policy objectives were informed, if not dominated, by price stability. This approach seemed successful. There was an extended period of price stability accompanied by stable growth and low unemployment. In the world before the crisis, central bankers were a triumphant lot. The unraveling of the Great Moderation has diluted, if not dissolved, the consensus around solely targeting inflation. The mainstream view before the crisis was that price stability and financial stability reinforce each other. The crisis has proved that wrong: price stability does not necessarily ensure financial stability. The crisis has given fresh impetus to the "new environment hypothesis" that pure inflation targeting is inadvisable and that the mandate of central banks should extend beyond price stability to include bank regulation and supervision, financial stability, and preventing asset price bubbles. 
What is the role of central banks in preventing asset price bubbles? The emerging view is that preventing an asset price buildup should be within the purview of a central bank. Opinion is divided, however, on whether central banks should prevent asset bubbles through monetary policy action or through regulatory action. What is indisputable, though, is that central banks' efforts to check asset price bubbles demand not just analytical capability but mature judgment of the nature of the risk.

Should central banks also engage in bank regulation and supervision? In many regulatory models the central bank is purely a monetary authority, with bank regulation and supervision vested in another agency. The emerging view is that the crisis was caused, at least in part, by a lack of coordination and communication between central banks and supervisors and, in the interest of financial stability, it is optimal to entrust regulation and supervision of banks to central banks. Admittedly, this is not a settled issue. There is no one-size-fits-all answer, as is clear from the variety of regulatory models around. Each country and each central bank will have to resolve this issue according to its specific circumstances.

\section{Central banks and financial stability}

While there is broad agreement that financial stability is neither automatic nor inevitable, there is less agreement on whether it should be explicitly included in the mandate of central banks. One argument is that explicit inclusion would be redundant, because financial stability is a necessary-although not sufficient-condition for achieving the conventional central bank objectives relating to inflation, output, and employment. On the other hand, there is a growing view that unless financial stability is explicitly included in the mandate of central banks, it is likely to fall through the cracks.

Complicating matters, defining financial stability in a precise, comprehensive, and measurable manner is proving to be difficult. Nevertheless, we now know that there are two attributes of financial instability:

- excessive volatility of macro variables such as interest rates and exchange rates that have a direct impact on the real economy; and

- financial institutions and markets threatened by illiquidity to the extent of jeopardizing systemic stability.

Do central banks have the instruments to address the mandate of financial stability? One clear instrument for preserving financial stability is the lender-of-last-resort function. During the crisis, central banks pumped in enormous amounts of liquidity to unfreeze the system through the lender-of-lastresort window. While this made individual institutions liquid, the market remained illiquid, thereby revealing the limitation of the window instrument in combating illiquidity. A central bank can infuse liquidity, but it's hard to ensure that the available cheap and abundant money is used to purchase assets whose value is rapidly eroding. The only option may be for the central bank to buy the assets. This means that the central bank must be not only the lender but also the market maker of last resort. These issues have yet to be clearly defined, let alone resolved. But they must be resolved soon.

\section{Managing the costs and benefits of regulation}

To safeguard financial stability, the Reserve Bank of India used a variety of prudential measures, including specification of exposure norms and preemptive tightening of the risk weights attached to assets and the requirements for loss provisioning. But these measures often carry a cost. For instance, tightening risk weights arguably tempers the flow of credit to certain sectors, but excessive, premature, or unnecessary tightening can blunt growth. Similarly, exposure norms offer protection against concentration risks; however, such limits can restrict the availability of credit for important growth sectors. Thus, as in the case of price stability, central banks face the challenge of managing the trade-off between financial stability and growth.

After a crisis, with the benefit of hindsight, all conservative policies appear safe. But excessive conservatism can thwart growth and stifle innovation. The question is, what price are we willing to pay, or-conversely-what potential benefits are we willing to give up, to cope with the unexpected, a black swan event? Experience shows that balancing the costs and benefits of regulation is more a question of good judgment than analytical skill. Central banks, especially those of developing countries, such as India, need to hone their judgment skills as they pursue growth and financial stability.

\section{Autonomy versus accountability}

During the crisis, governments and central banks coordinated their efforts to launch unprecedented expansionary fiscal and monetary policies. As countries contemplate exiting these expansionary policies, the familiar tensions between monetary and fiscal policies are showing up again. And a possible return of fiscal dominance could undermine the independence of central banks.

Responsibility for financial stability must be shared by the government, the central bank, and other regulators. Although that shared responsibility is not in itself a problem, there are two related concerns. The first is that the rescue of financial institutions is an inherently political act, and involvement in such decisions may compromise central banks' technocratic credentials. The second concern is the risk that coordination with the government for the purpose of financial stability may spill over into other areas within central banks' purview, thereby undermining their independence.

The case for central bank independence is coming under increasing assault as a result of crisis-spawned developments. Central banks must advocate for independence not with weighty arguments but through more vigorous and voluntary efforts to be transparent, responsive, and accountable.

This list of issues addressed here is by no means exhaustive, nor have all the nuances been considered. But central banks must gain a better understanding of how to begin tackling these issues, and on that basis adapt and change the way they function.

Duvvuri Subbarao is Governor of the Reserve Bank of India. 


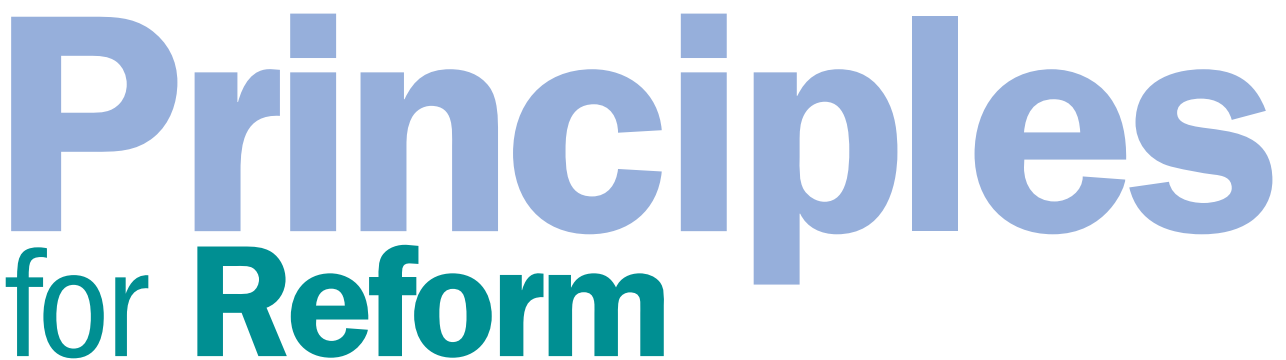

\section{In designing new policies for the financial sector, old-fashioned ideas are important}

\section{William Poole}

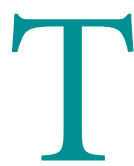

HE financial crisis has caused widespread reevaluation of public policy toward the financial sector and financial regulation. Many reform plans have been proposed, but little has been settled. Political pressure on legislatures in many countries around the world is substantial, portending a collision between industry lobbying and popular conceptions, including misperceptions, of the nature of needed reforms.

Reform issues facing developing economies may seem different from those confronting advanced economies, but they are fundamentally the same. Policymakers in developing countries must maintain a vision of the financial sector they desire to foster, to avoid policies today that will make it difficult to achieve that vision. Too often policies viewed as short-term expedients create vested interests that are difficult to dismantle. The issue is particularly serious when it comes to regulatory constraints, which shape and distort the structure of financial services industries. Protected segments fight to retain their advantages, and regulatory agencies fight to retain influence. In general, there is a long record of establishing government agencies, but the record of their dismantling is woefully short.

It is also essential to have a vision of the financial structure of the future, because finance is inherently competitive around the globe, making it difficult and costly to prevent domestic nonfinancial firms from obtaining financial services abroad. Therefore, nurturing a domestic financial services industry requires attention to international competition, and that means attention to the characteristics of the most sophisticated types of financial services. Financial and nonfinancial industries face the same issues: a developing economy that aims to join the advanced economy club must be open to practices and technologies that raise productivity and income.

The financial crisis in the United States and Europe demonstrates that the financial system was defective and cannot be the basis of the financial vision for developing economies. What follows is my view of the core principles that ought to guide thinking about how to direct public policies toward financial services industries in all types of economies. I will speak loosely of central bank powers and regulators' powers, with the understanding that institutional arrangements differ from one country to another.

\section{Price-level stability}

The most important goal of a central bank should be maintenance of reasonable stability of the economy's general level of prices. Price-level stability aids economic development and helps maintain domestic and international confidence in an economy. Domestic markets, especially capital markets, function more efficiently when prices are stable.

A central bank that is successful in maintaining price stability will gain prestige and influence. Moreover-a point often neglected — when a central bank maintains price stability, it is in a position to pursue countercyclical monetary policy that will help stabilize employment at a high level.

\section{Payments are paramount}

No economy can function without a reliable mechanism for making and receiving payments. Neglecting the old-fashioned monetary functions of banks is a recipe for disaster. A commercial bank is simultaneously a monetary firm, accepting and transferring deposits, and a credit firm, making and administering loans. When the credit activities of banks create the potential for insolvency, their monetary functions are seriously impaired.

There are two defenses against the risk of bank insolvency. The first, and most important, is a requirement that commercial banks maintain a large capital cushion in exchange for the benefits of a bank charter. The recent financial crisis demonstrates that traditional standards of bank capital were not adequate. Banks should be required to maintain minimum equity capital of 10 percent of assets. In addition, 10 percent of total liabilities should be in the form of subordinated long-term debt, which the bank may convert into equity on maturity (sometimes called "contingent capital").

A stiff capital requirement serves several purposes. It maintains market confidence in the solvency of the banking system, imposes substantial market discipline over the activities of banks, and provides a large cushion to protect taxpayers from the risk being called on to bail out failing banks. 
The second defense against bank insolvency is regulatory oversight. Banking systems generally enjoy governmentprovided deposit insurance. Oversight is necessary to protect the deposit insurance fund. Banking authorities should be charged with the single function of maintaining safety and soundness of banks. Banks should not be used to provide government-directed development finance. Strong banks are central to the development process, but their credit activities should be motivated by private-market considerations.

There are dangers to using banks as development agencies. One is that banks will be pressured into making loans that are not safe. A second is that government-directed bank credit activities are off budget. A government that wants to encourage development lending should do so transparently through government credit agencies whose resources are provided through the usual legislative process. Alternatively, governments can choose to subsidize private development firms. Because of the critical importance of banking stability, banks should not be a directed part of development finance.

\section{The poison of excessive leverage}

The primary cause of the current financial crisis was excessive leverage, especially in the banking system. In the context of U.S. experience over the past decade, it is interesting to compare the dot-com stock bust early in the decade with the subprime mortgage bust that started in 2007. Both episodes were characterized by a mania for risky assets that wound up visiting large losses on investors; however, only the subprime bust resulted in a financial crisis. Common stock was held largely in unleveraged accounts - in individual and mutual fund portfolios. Subprime mortgages and the securities issued against them were held in highly leveraged accounts in commercial and investment banks and some hedge funds.

Despite the poison of excessive leverage, tax systems generally subsidize debt by making interest a deductible business expense but not dividends on equity. Public policies that subsidize leverage make no sense. Individual and business income tax systems should phase out deductibility of interest and reduce tax rates to compensate, so that the reform is revenue neutral.

\section{Regulatory discretion}

Most regulators, most of the time, believe they can function more effectively if they have broader powers. That view needs to be challenged.

Every official in a democratic society functions under political constraints. A central bank governor, for example, knows that the position does not carry unlimited power, no matter how broad the statutory authority. At issue is always which actions can be pursued in the current political environment. Equally important, clear thinking about financial structure calls for consideration of the powers a central bank should not want to exercise, but might feel compelled to use if such power is contained in the controlling legislation.

For example, should a central bank buy obligations of private firms and local governments? If the answer is, as I believe it should be, that the central bank should not pro- vide such loans, then it should not have the power to do so. Loans to entities other than banks should be the responsibility of the elected government. Emergency authority should be narrowly drawn, perhaps requiring formal assent from the prime minister or president to ensure that central bank resources are not misused. The issue is not that central banks will routinely misuse their lending powers but that political authorities will misuse central bank powers. Requiring political assent increases the transparency of central bank lending to nonbanks and places responsibility for such loans with political authorities, where it belongs.

Central bank lending ultimately depends on the power to create money; exercising that power wisely is necessary to maintain the purchasing power of the currency. Central bank independence from day-to-day political control is the best protection from inflationary finance. This is why a narrow definition of central bank powers and responsibilities is essential.

It is helpful to think through in advance which powers agencies need and should have. Arguing for extremely broad and vague power in the name of flexibility can be, I fear, a result of the failure to think issues through clearly. Every scholar knows how valuable the teaching experience is in sharpening ideas. Every regulator should be asking questions of this kind: If $\mathrm{X}$ happens, what should my agency do? What powers are needed? If $Y$ happens, will those same powers be subject to abuse through the political process?

Over time, senior leadership in every agency changes. How confident can we be that future leaders will exercise broad authority wisely? When contemplating legislative changes, a good rule is to presume that future leaders will not have the same competence and motives they have today. Controlling legislation should constrain rather than enable future leaders, which is the only way to provide markets reasonable assurance of sound policies.

\section{Old-fashioned, but important}

The financial crisis demonstrates the continuing importance of some old-fashioned ideas. Because a banking crisis creates a general economic crisis, the laws and regulations that govern the financial sector must above all maintain stability in the commercial banking sector. Banks must focus on relatively low-risk lending and maintain substantial capital. The powers of regulatory agencies must be carefully designed; excessive power invites political misuse and creates market uncertainty about authorities' actions.

There must be much more effort to change the incentives for financial firms. Changing tax laws to encourage less leverage and larger capital requirements for banks will lead to a more stable financial system. Although financial crises have been a staple of market economies for centuries, we know enough about their causes to design policies to make such instabilities much less common in the future.

William Poole, former president of the Federal Reserve Bank of St. Louis, is Senior Fellow at the Cato Institute and Distinguished Scholar in Residence at the University of Delaware. 


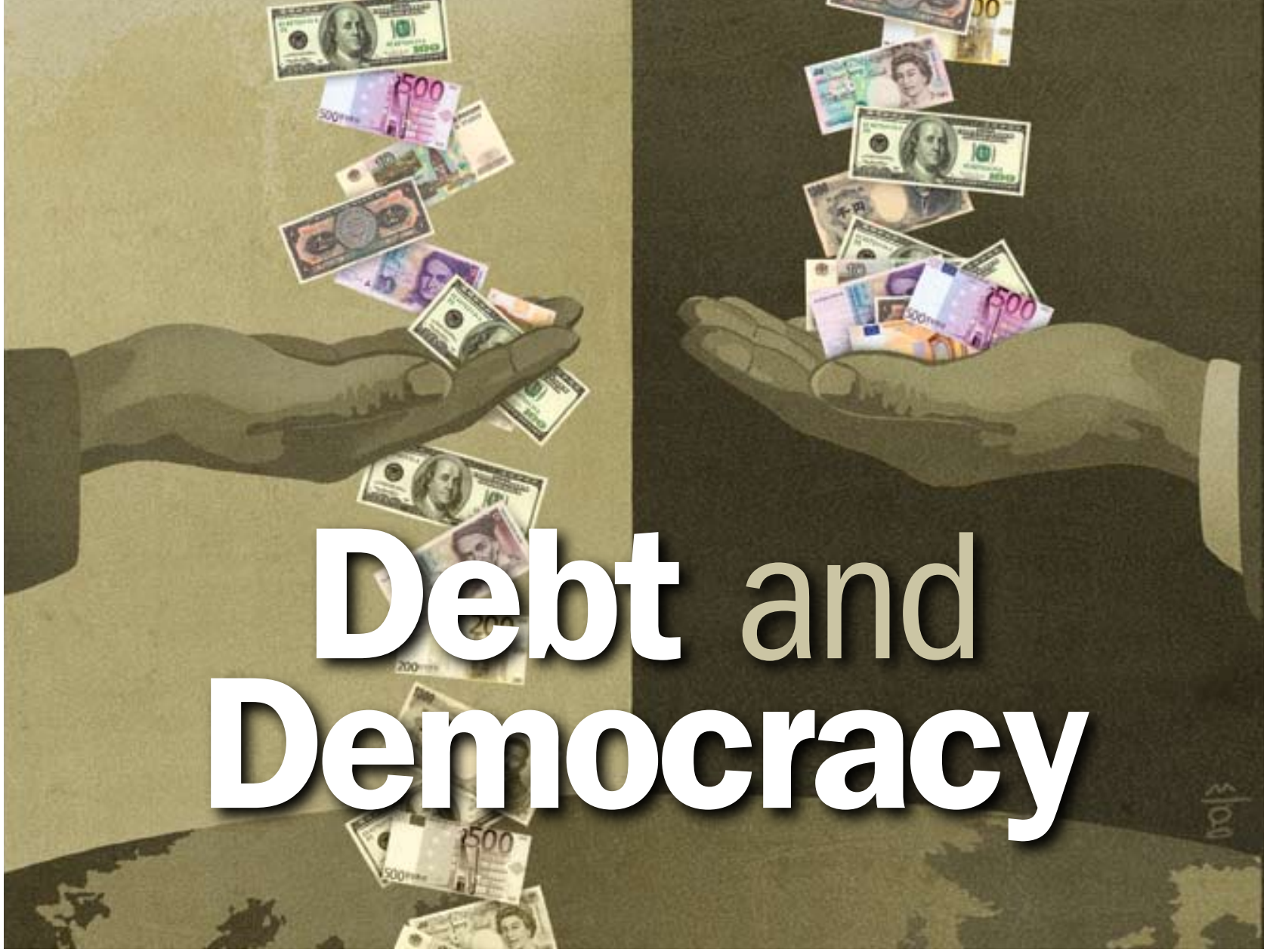

Rabah Arezki and Markus Brückner

Democracies use windfalls from

international

commodity

price booms

to reduce

external debt.

Autocracies

tend to spend them
OMMODITY-exporting countries often experience large commodity price shocks that pose serious challenges to their macroeconomic stability. For example, the sudden influx of foreign earnings from a surge in commodity prices can increase a country's real exchange rate (the nominal exchange rate, adjusted for inflation) and make its noncommodity exports less competitive. The effect of such unanticipated price changes on the competitiveness of commodity exporters has been studied widely by economists.

There are other significant, if less studied, repercussions on commodity-exporting countries from such price shocks, which boost both foreign reserves and government revenue. The way the government uses revenue earned from a commodity price surge has a direct effect on a country's macroeconomic performance and can be beneficial or harmful.

When prices boom, the sudden increase in revenue makes it easier for commodityexporting countries to repay their external debt. But booms end. A wise use of the revenue earned during good times would be to pay down external borrowing to prepare for leaner times. But a country that does not make judicious use of the windfall-or even uses the boom to accumulate more debt-may find itself in more difficulty. That is because debt would become a bigger portion of its diminished post-boom financial resources and would be harder to pay. The situation is compounded if, as is often the case, the debt is denominated in a foreign currency, such as U.S. dollars. If a windfall received during a commodity price boom is not used to reduce external debt, an external debt default (loosely defined here to include debt restructuring, even if there is no formal default) may follow. Some researchers argue that the 1970s commodity price booms spawned excessive external debt in a number of commodity-exporting countries-for example, Venezuela and Nigeria-which led to the debt crises of the 1980s (Deaton, 1996; Krueger, 1987; Sachs, 1989a).

The prevailing view in international finance literature is that high levels of external debt undermine economic performance by effectively acting as a tax on future investment projects and constraining the financing of these projects (Krugman, 1988; Sachs, 1989b). Given large swings in commodity prices in recent years and the 2009 debt crisis in Dubai, 
policymakers must gain an understanding of the link between the external debt of commodity-exporting countries and movements in international commodity prices. We investigated that link by studying 93 countries during 1970-2007 and concluded that there was a significant difference between the way democracies and autocracies handled the boom. We focused on government behavior regarding gross external debt as is common in the literature. It is important to remember, however, that some countries have also accumulated financial assets such as international reserves that reduce their overall net position with the rest of the world.

\section{What windfalls bring}

In democratic countries (see Box 1), where political institutions hold political leaders to some degree of accountability, positive commodity price shocks are associated with significantly less external debt and risk of default on that debt. In countries with deep autocratic regimes, where political leaders have little or no public accountability, windfalls from international commodity price booms were not used systematically to reduce external debt; moreover, the risk of default on external debt significantly increased in these countries after revenue windfalls from commodity price booms ceased.

Why? Because these regimes used a large part of those windfalls on government consumption. Increases in government consumption expenditures are not necessarily harmful. Indeed, from the standpoint of social welfare, if a windfall is used to provide public goods such as education and health services in an efficient manner, the spending can be beneficial.

But in autocracies, the increases in government consumption expenditures were mostly unproductive, largely benefiting powerful elites. In oil-exporting countries, for example, fuel products were often subsidized, resulting in large fiscal costs and overconsumption, which disproportionately helped the rich, who consume much more energy than the poor (see "Reducing the Staggering Costs of Cheap Energy" in this issue of $F \& D)$. Because spending in what have been called countries with "grabber-friendly political institutions" squanders public funds and crowds out production activity (Mehlum, Moene, and Torvik, 2006), per capita gross domestic product (GDP) - a common, if incomplete, measure of social welfare-does not increase during commodity price booms.

In democracies, on the other hand, we did not find a large and significant increase in government consumption expenditures during commodity price booms. The revenue windfalls led to a significant increase in per capita GDP.

We also found that in democracies, international commodity price booms were often accompanied by a significant improvement in the rule of law (see Box 2). Increases in the international prices of exported commodities may raise the return on domestic investment, especially in the resource sector, but if investors fear expropriation by the government of a significant portion of their profits, private investment may not increase significantly despite a higher return on domestic capital. Many democracies responded to investors' fears by providing assurance to potential investors that their property rights would be respected. In many autocracies, by contrast, the rule of law was already weak and did not improve-or even deteriorated-during international commodity price boom windfalls.

\section{What is there to learn?}

More conservative administration of windfalls in countries with more democratic institutions yields a clear benefit: reduction of external debt. And that means a lower tax burden on future investment projects. So most citizens prefer policies that reduce external debt, especially if there is a serious risk that the government will squander revenue windfalls from international commodity price booms on low-return projects. Democratically elected political leaders, because they are accountable to the public, appear more willing than their autocratic counterparts to promote (or accede to) external debt reduction.

\section{History repeats}

As a result of international financial deregulation in the 1990s and the associated capital flows from industrial to developing economies, many countries suffered excessive indebtedness, which led to the 1990s debt overhang (existing debt high enough to deter investment). Multilateral and bilateral creditors provided systematic debt relief for the poorest economies. Among those benefiting were several low-income but commodity-rich countries. But when commodity prices began to boom again after 2000, some of those commodity-rich countries, especially in sub-Saharan Africa,

Box 1

\section{Democracy or autocracy}

We divided the 93 countries in our study into democracies and autocracies, based on the criteria set in the Polity IV database (Marshall and Jaggers, 2009). The classification uses a 10point scale that categorizes four attributes of political systems: the competitiveness of political participation, the competitiveness of executive recruitment, the openness of executive recruitment, and the constraints on the chief executive.

At one end of the scale, +10 , are the most politically competitive and open democracies. At the other, -10 , are the least open and competitive autocracies. We considered a country to be autocratic if the average score over the period 1970-2007 was below zero, and deeply autocratic if it was below -6 . Democratic countries had a score above zero, and those that were strongly democratic registered above +6 . Of the 93 countries, 52 were autocratic, 13 deeply so, and 41 were democratic, 14 of them strongly democratic.

\section{Box 2}

\section{Rule of law}

There are two aspects to the rule of law (International Country Risk Guide, 2009). The law component captures the strength and impartiality of the legal system. The rule of law also encompasses the notion of "order," that is, how well the laws are followed. A country can have a highly rated judicial system but an overall low rating if it has a very high crime rate or if its citizens routinely ignore laws with impunity. 
began to borrow heavily-from China and other new creditors. This new borrowing raises questions about the sustainability of commodity-rich countries' public finances and the possibility of a new vicious cycle of excessive indebtedness and another debt overhang.

To limit those risks, commodity-rich countries with poor records of fiscal discipline-especially autocracies-should consider implementing government budget rules at the outset of a commodity price boom. Fiscal rules are numerical targets on budget aggregates-such as the structural deficit (the difference between government spending and revenue, adjusted for the state of the business cycle), expenditures, and debt. In theory, fiscal rules make sense because they aim to prevent commodity-rich countries from borrowing excessively. In practice, fiscal rules are not always effective. Indeed, creative accounting, political pressure, and the abuse of public office for private purposes can affect a government's commitment to the implementation of fiscal rules. This is especially true in the arbitrary world of autocracies. Difficulties with the implementation of fiscal rules include the design of an appropriate system of checks and balances and of a public communication strategy. These difficulties signal a need for more research and debate over policy design in environments with poor governance.

Rabah Arezki is an Economist in the IMF Institute, and Markus Brückner is a Ph.D. candidate at Pompeu Fabra University.
This article is based on IMF Working Paper 10/53, "International Commodity Price Shocks, Democracy, and External Debt."

\section{References:}

Deaton, Angus, and Ron Miller, 1996, "International Commodity Prices, Macroeconomic Performance, and Politics in Sub-Saharan Africa," Journal of African Economies, Vol. 5, No. 3, pp. 99-91.

International Country Risk Guide, 2009, PRS Group (Syracuse, New York).

Krueger, Anne O., 1987, “Origins of the Developing Countries' Debt Crisis, 1970 to 1982," Journal of Development Economics, Vol. 27, No. 1-2, pp.165-87.

Krugman, Paul, 1988, "Financing vs. Forgiving a Debt Overhang," Journal of Development Economics, Vol. 29, No. 3, pp. 253-68.

Marshall, Monty G., and Keith Jaggers, 2009, Polity IV Project: Political Regime Characteristics and Transitions, 1800-2007-Dataset Users' Manual (Arlington, Virginia: Polity IV Project).

Mehlum, Halvor, Karl Moene, and Ragnar Torvik, 2006, "Institutions and the Resource Curse," Economic Journal, Vol. 1, No. 508, pp. 1-20.

Sachs, Jeffrey D., 1989a, "Introduction to 'Developing Country Debt and Economic Performance," in Developing Country Debt and Economic Performance, Volume 1: The International Financial System (Cambridge, Massachusetts: National Bureau of Economic Research), pp. 1-36.

—, 1989b, "The Debt Overhang of Developing Countries," in Debt Stabilization and Development: Essays in Memory of Carlos DiazAlejandro, ed. by Guillermo Calvo and others (Cambridge, Massachusetts, and Oxford: Blackwell), pp. 80-102.

\section{ก่อ COLUMBIA ISIPA}

\section{School of International and Public Affairs}

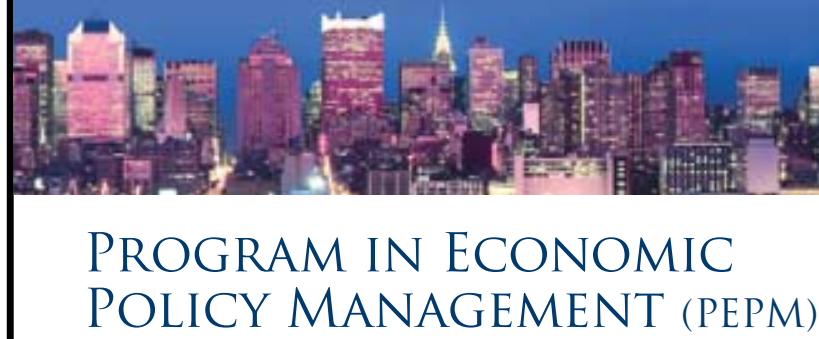

Confront global economic challenges

with the world's leading economists,

policymakers, and expert practitioners,

including Jagdish Bhagwati, Guillermo

Calvo, Robert Mundell, Arvind Panagari-

ya, and many others.

A 14-month mid-career Master of Public Administration focusing on:

- rigorous graduate training in micro- and macroeconomics

- emphasis on the policy issues faced by developing economies

- option to focus on Economic Policy Management or International Energy Management

- tailored seminar series on inflation targeting, international finance, and financial crises

- three-month capstone internship at the World Bank, IMF, or other public or private sector institution

The 2011-2012 program begins in July of 2011.

Applications are due by January 1, 2011. 

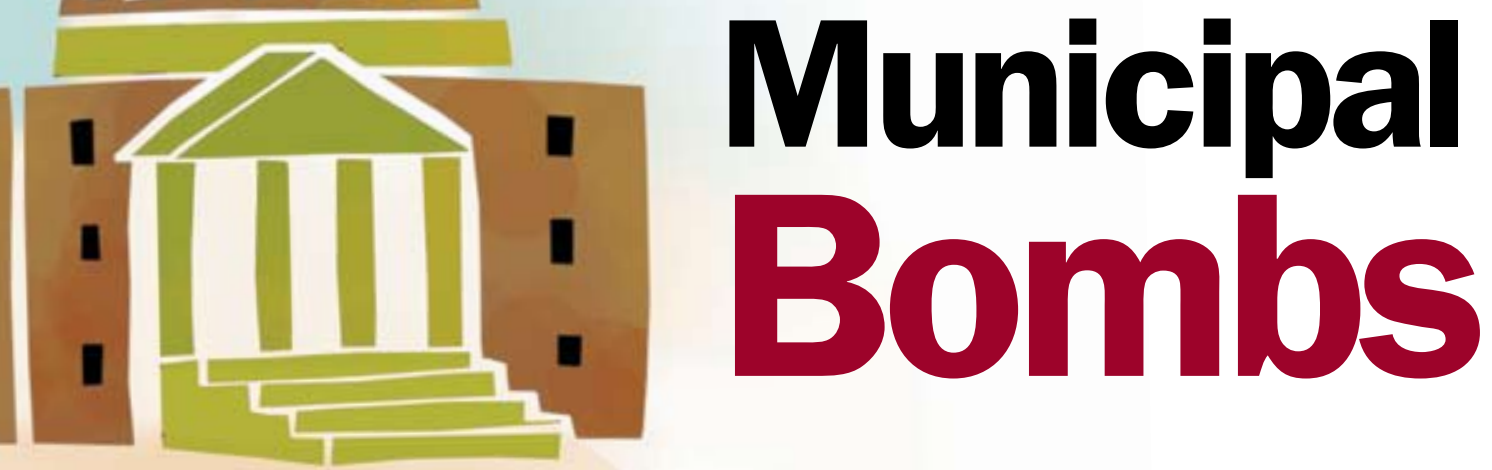

Randall Dodd

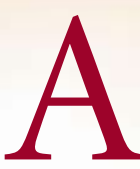

SIDE from some shared namesand the movie Paris, Texas, which celebrates one of them-there seem to be few connections between European and U.S. cities. But modern finance has changed that some. Similar but complex derivatives transactions on both sides of the Atlantic have resulted in crippling financial losses for local governments.

The deals went sour in part because of the global economic crisis, which showed that many supposedly sound transactions were riskier than the municipalities believed. These deals usually involved unsophisticated local governments making deals using derivatives (see box) traded over the counter between two parties, rather than on an organized exchange or through a central clearing counterparty.

France has a reported $€ 11$ billion in outstanding notional amounts of derivatives involving 1,000 cities (a notional amount is akin to the face value of a bond). In Italy there are 467 cities with a reported $€ 2.5$ billion outstanding. Comprehensive data for Germany are not available, but at least 50 cities have derivatives transactions with Deutsche Bank alone. In the United States, where 40 states have passed laws authorizing municipal authorities to trade derivatives, such transactions have a total estimated notional amount of $\$ 250-\$ 500$ billion. As in Europe, financial disasters related to trading in those instruments have come to light in court actions. In the United States, large losses have been reported in cities and counties in Alabama, California, Ohio, and Pennsylvania, and like those in Europe, many U.S. municipalities have not publicized their bad trades, presumably to avoid embarrassment and political consequences. As a result, although there are sizable losses on both continents, comprehensive numbers are not available.

Some municipalities got into trouble simply trying to lower the cost of issuing debt for such common local government responsibilities as improvements to schools or water treatment facilities. Other governments were trying to use derivatives to cloak their debt or budget deficits. Once they got into trouble, they became susceptible to greater dangers as they traded more complex or exotic-and riskier-derivatives to recoup their losses.

\section{Textbook arbitrage}

Governments most frequently entered into a common type of derivative transaction called a swap contract to lower expected borrowing costs. A common swap involves an exchange of a fixed stream of income for a floating stream. Municipalities got into trouble when they instead issued bonds with a variable, or floating, rate, and then entered into an interest rate swap transaction (with a dealer, usually a commercial or investment bank) to convert

\section{What is a derivative?}

A derivative is a financial contract whose value depends on or derives from-hence the name-an underlying reference item, such as a stock, bond, currency, or interest rate. Futures contracts, options, and swaps are among the most common types of derivatives. Some derivatives are traded on exchanges, others over the counter. They are often used to hedge risk.

\section{Local governments on both sides of the Atlantic found themselves in a financial mess after engaging in derivatives transactions}


the variable rate into a fixed rate-a process called synthetic fixed rate debt. That fixed rate was supposed to be lower than what the municipality would have paid had it issued a standard fixed-rate bond. Although converting a variable rate into a fixed rate was the intent, it was achieved by netting out two variable payments-between the floating rate the municipality paid on the bonds and the floating rate it received in the swap. The expected difference between the two floating rates was projected to save the municipality 0.5 to 1.5 percentage points on its debt.

This is a standard derivative strategy, long used by nonfinancial firms. It posed problems for municipalities when the floating rate on the municipal bonds they issued did not move in sync with the benchmark rate that determined the payments received from the swap dealers. These interest rates might track each other closely under ordinary market conditions, but diverge sharply during a crisis, when market pressures affected them differently. When the interest rates ceased moving in tandem, the netting of the two variable rates no longer resulted in the fixed-rate goal and municipalities ceased to save on their interest payments. The potential for such a negative development is called "basis" risk. Municipalities' savings on interest rates often turned to losses as interest rate paths diverged.

Between 2002 and the end of 2007 there was a fairly reliable difference, called a spread or basis, between the London interbank offered rate (LIBOR), a commonly used benchmark for municipal bond issues, and the Securities Industry and Financial Markets Association (SIFMA) index, often used to determine the municipal swap rate. But that spread became alarmingly volatile between 2008 and March 2009

\section{When rates diverge}

The difference, or spread, between LIBOR and the SIFMA index was steady from 2006 to 2008 but became volatile after that, upsetting municipal securities rates based on that spread and costing local governments much money.

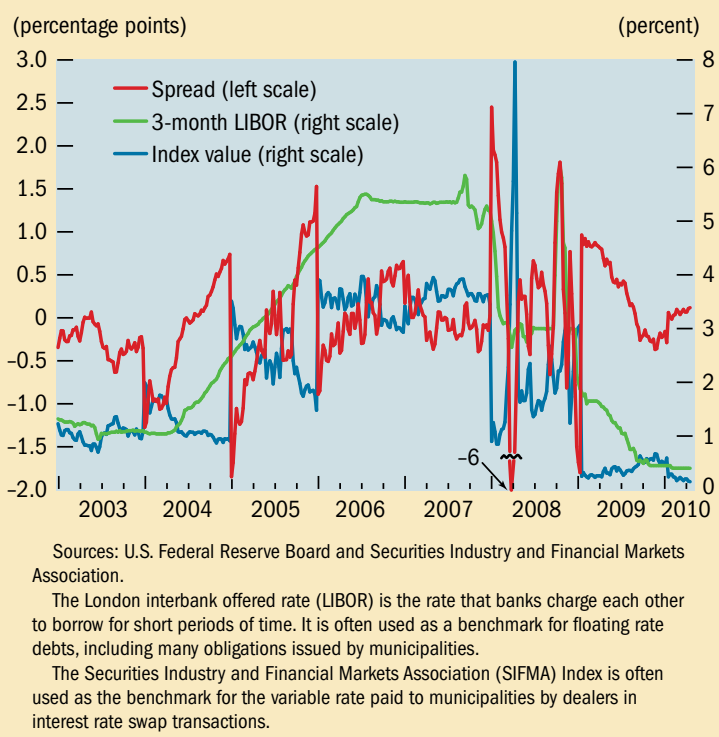

(see chart), and municipalities generally wound up paying higher-often much higher-rates than anticipated.

The situation became more complicated when the rates municipalities paid on their long-term variable rate bonds were not linked to a benchmark rate, but were set directly by the market at regular weekly or monthly auctions. In addition to a mismatch between individual market-based financing rates and benchmark interest rates, during the global financial crisis the auctions often failed, because there were no bidders for the bonds-not even the broker-dealers that had underwritten the securities. Those broker-dealers were hampered by their own shortage of capital and funding difficulties. When the auctions failed, the rates on the securities skyrocketed because of clauses in the contracts that set high penalty interest rates in the event of such a failure.

A strategy designed to save on interest costs did not adequately address basis risk-that is, that spreads might widen. The transactions followed a period of low volatility in interest rate spreads that suggested low probability of future problems. Now it is clear that the past was not a good guide for the future, and that the expected savings were not sufficient once an accurate measure of risk was taken into account.

\section{Getting the money up front}

Municipalities also used interest rate swap transactions that offered them up-front payments, which they could use to reduce debt or pay for current expenses, in return paying more than they would otherwise have had to over the term of the swap. Interest rate swaps are typically priced at par, which means that the fair market value of each side (or "leg," in swap parlance) is the same at the outset of the deal. However if a municipal government contracts to pay a fixed-rate leg that is higher than the prevailing market rate, the dealer pays the value of those higher future payments to the local government at the outset of the deal. In municipal accounting systems that are on a cash rather than accrual basis, such a transaction would not usually be reported as a government debt even though the municipality has, in effect, borrowed. That distorts the municipality's reported fiscal condition.

\section{Exotic deals}

The third, and sometimes most damaging, case involved more complex or exotic derivatives. Municipalities seeking to recover losses on other derivatives transactions, or merely to enhance the returns on their cash assets during a period of low interest rates, entered into derivatives transactions such as constant maturity swaps (CMS), swaptions, and snowballs. Because they were more complex and opaque, these swaps were more difficult to price and their risks were less clear. Moreover, their primary purpose usually was not to hedge risk but to generate higher income by taking on more risk. A major question is whether they were priced fairly.

A CMS is an interest rate swap in which one side's payment is based on a short-term benchmark rate such as threemonth LIBOR plus a spread and the other side pays, say, the 10 -year swap rate in effect on each payment date during the life of the swap. It essentially is a bet on the slope of the yield 
curve-which plots the relationship between the income an investment yields and its maturity. In normal times, yields are lower the shorter the maturity and the curve slopes upward (because of a combination of risk factors that increase over time). The key selling point for these transactions was that when the benchmark rate was high, the net payment between the two would be close to zero. If the central bank lowered short-term rates, the yield curve would likely steepen, because long-term rates would not fall as much. The swap would generate a cash flow to the municipality. But during the financial crisis both short- and long-term rates fell, and the slope of the yield curve flattened. Twenty-seven school districts in Pennsylvania alone are reported to have lost money on these types of contracts since 2006 .

\section{The losses generated by many of these derivatives trades created large problems in local governments.}

A complex variation of a CMS is an exotic derivative called a snowball. Snowball investments contributed to losses in cities such as St. Etienne, France, and Pforzheim, Germany. (St. Etienne also suffered major losses on currency swaps that involved pounds sterling and Swiss francs.) These snowballs, like CMS, derived their value from the difference between long- and shorter-term interest rates. But an added mechanism required that each period's payment be no lower than the previous period's. Thus an unfavorable movement in interest rates, even if temporary, would generate a permanent increase in payments over the life of the contract-and maturities sometimes extended for decades. This is good business for the party on the winning side of the transaction-which the municipalities frequently were not.

\section{An instance of all three problems}

In the United States, Jefferson County, Alabama, managed to get ensnared in all three scenarios-trying to lower interest costs, to generate up-front payments, and to earn extra income. The county, with fewer than 700,000 people, traded 17 swaps with a combined outstanding notional value of $\$ 5.8$ billion and maturities extending up to 39 years. Not only has the county lost $\$ 277$ million on the derivatives transactions, but there are indications that excess commissions of about $\$ 100$ million were paid in conjunction with those transactions.

One of the Jefferson County swaps illustrates how complexity can create asymmetric pricing knowledge-a situation in which one side knows more than the other about the transaction - that results in a product being priced unfairly. The swap in question was designed to generate an up-front payment of $\$ 25$ million and extra income for the county, which took on additional interest rate risk to get the higher income. The swap payments, based on notional principal of $\$ 1.88$ billion, were the net difference between the county's paying one-month LIBOR times 0.67 percent and receiving one-month LIBOR times 0.56 percent plus 0.49 percent of the principal. The formula is equivalent to the county's paying LIBOR times 0.11 percent $(0.67$ percent minus 0.56 percent) and receiving a fixed payment of 0.49 percent.

The terms of the agreement are expressed as percentages of interest rates, which makes the transaction harder to understand. Consider the following reverse financial engineering, which, because maturity details are not public, assumes a maturity of 10 years. The terms are identicaland the transaction is easier to understand-when the interest rates are increased 10 times and the principal is reduced by a similar amount. The payment terms can be expressed as the county's paying the difference of 1.1 times LIBOR times the $\$ 188$ million in notional principal less 4.9 percent. The standard 10-year fixed rate for a LIBOR interest rate swap in June 2004, when the deal was made, would have allowed the county to pay straight LIBOR and receive 5.23 percent of the principal. At the then-prevailing swap rate, the 1.1 times LIBOR the county paid would have been exchanged for 5.75 percent -0.85 percentage point more than the 4.90 percent it received.

The swap dealer, on the other hand, received these higher payments. After paying 4.9 percent to the county, it had a virtually risk-free return of 0.85 percent on principal of $\$ 188$ million. The present value of this return in June 2004 would have been $\$ 125$ million-allowing the dealer to pay $\$ 25$ million up front to Jefferson County and earn a profit of $\$ 100$ million. The only risk to the dealer was the "credit" risk that either Jefferson County or the counterparty to the other swap would default. The county, on the other hand, took on a large amount of interest rate risk and did so at a below-market rate of return.

This transaction illustrates how complex and nontransparent instruments traded over the counter were used in derivatives transactions with unsophisticated municipalities. It also shows how contracts can be written in ways that obscure the underlying economics.

The losses generated by many of these derivatives trades created large problems in local governments. Towns such as St. Etienne and Pforzheim and Alabama's Jefferson County had to cut spending significantly_reducing current services and delaying or curtailing public infrastructure investment, which has dampened real economic activity.

To help them avoid transactions they don't understand, municipalities should be required to consult genuinely independent third party advisors who can analyze risk and provide independent pricing. Municipalities should pay these advisors a set fee, not a percentage of the transaction. Derivatives dealers should act with fiduciary responsibility and be required to establish the suitability of trades with municipalities and ensure transactional transparency. In addition, governments' accounting rules should be updated to address the use of derivatives in municipal finance.

Randall Dodd is a former Senior Financial Expert in the IMF's Monetary and Capital Markets Department. 
middle-income economies of debt-to-GDP ratio declines of more than 20 percentage points over at least two years. Median debt reduction was 34 percent of GDP and lasted for $5 \frac{1}{2}$ years, with an average primary fiscal surplus of $23 / 4$ percent of GDP. There has been considerable variation in the size of total debt reduction and the average primary balance (see Chart 1).

Cases of large debt reduction generally fall into three groups:

- oil exporters, which benefited from favorable price developments or expansion in extraction capacity;

- debt restructuring cases, which received support from creditors and were often helped by a quick economic recovery after a crisis; and

- other cases, which achieved debt reduction through a combination of homegrown fiscal adjustment and favorable "automatic" debt dynamics. Usually these dynamics included a combination of strong economic growth and relatively low interest rates and-for countries whose debt is denominated in foreign exchange-real exchange rate appreciation.

\section{Oil exporters-filling up}

Not surprisingly, oil exporters achieved a higher increase in the primary fiscal balance than other countries during debt reduction episodes, because buoyant oil prices and/or increases in production led to higher fiscal revenues (see Chart 2). Oil

\section{Chart 1}

\section{A scattered pack}

Countries' experiences with debt reduction and fiscal adjustment have varied widely.

(percent of GDP)

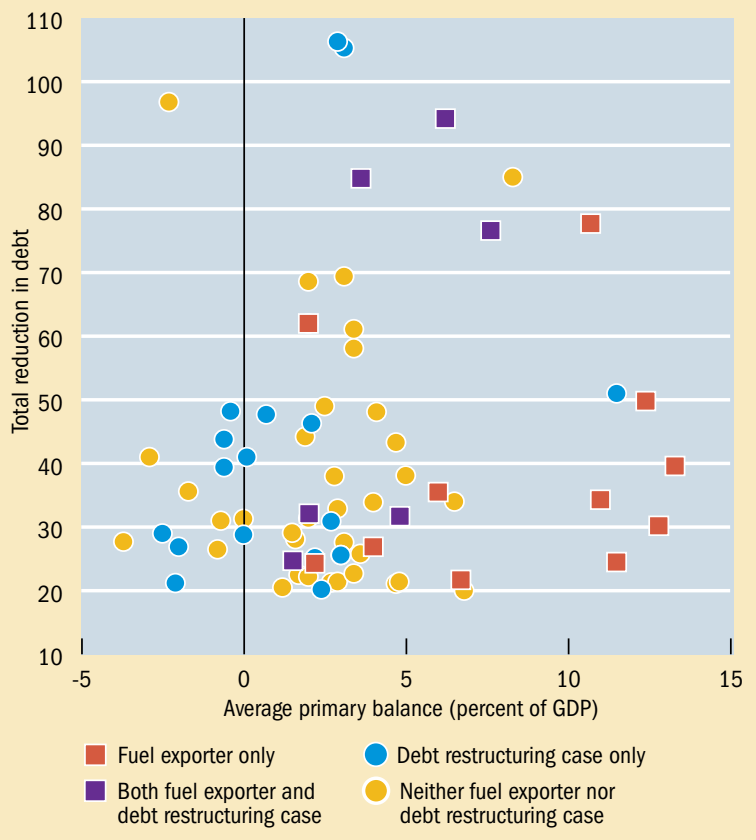

Sources: IMF, World Economic Outlook; and IMF staff estimates.

\section{Chart 2}

\section{Grouping the field}

Oil exporters profited from terms-of-trade improvements; debt restructuring cases benefited from GDP growth and real exchange rate appreciation.

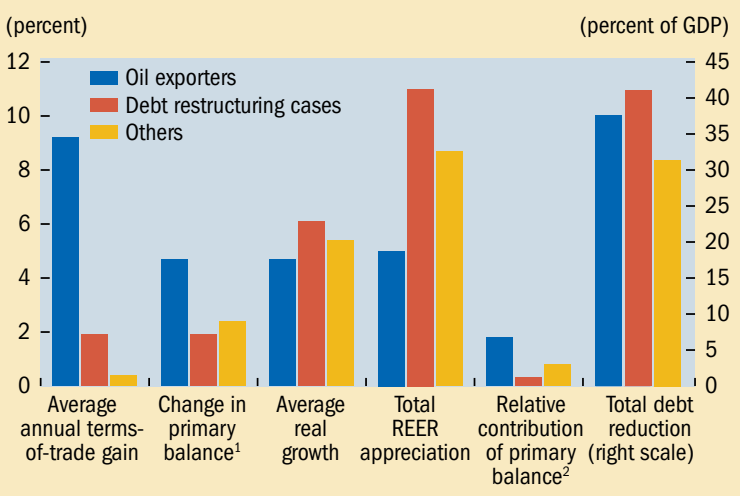

Sources: IMF, International Financial Statistics, World Economic Outlook, and staff estimates; Joint External Debt Hub database; and World Bank, World Development Report. Note: REER = real effective exchange rate.

${ }^{1} O$ ver the preceding three-year period; in percentage points of GDP.

${ }^{2}$ Ratio of contribution to overall debt reduction of the primary balance to the contribution of automatic debt dynamics.

exporters' average terms-of-trade improvement was several times that of other countries. But oil exporters consolidated their primary expenditures somewhat less, perhaps because the oil windfall reduced the urgency of cutting expenditures. Nonetheless, oil exporters are the only group whose primary balance contributed more to debt-to-GDP ratio reduction than did the automatic debt dynamics resulting from favorable developments in growth, interest rates, and the exchange rate.

\section{Debt restructuring cases-reenergized}

By contrast, in cases that involved debt restructuring-with either private creditors or the Paris Club-the primary balance contributed less to overall debt reduction than in the other groups. Granted, in the first year of the debt reduction episode, the primary fiscal adjustment was on average slightly higher in the debt restructuring cases than among other cases (oil exporters aside), but over the entire debt reduction period, a different picture emerges. For the debt restructuring cases-despite tightening of the primary balance by about 2 percent of GDP during such periods-primary balances on average reached only 0.7 percent of GDP, markedly less than among oil exporters (6.4 percent) and other cases (2.8 percent).

This may seem puzzling: one might expect that creditors would demand higher primary surpluses in exchange for debt relief. But the favorable debt dynamics triggered by more generous debt service terms and, in many cases, quick recovery of the economy and real exchange rate appreciation after a crisis effectively reduced the need for primary fiscal adjustment during debt reduction episodes. In fact, the debt restructuring cases achieved on average the largest debt reductions (41 percent of GDP, compared with 38 per- 
cent among oil exporters and 31 percent among other cases), even though they had the lowest primary surpluses among the three groups. Apart from direct debt relief from the terms of the restructuring, the debt restructuring cases were also helped by high GDP growth (6 percent) and substantial real exchange rate appreciation (11 percent over the duration of the episode).

Although it may thus sound tempting to solve debt problems via restructuring, growing financial interlinkages make that route increasingly costly for both the country undergoing restructuring and the international community to which it is linked.

\section{Growing out of debt}

Among the 43 countries that are neither oil exporters nor benefited from debt restructuring-especially cases in the Middle East and Central Asia (MECA; see Chart 3) - there was a tendency to rely more heavily on automatic debt dynamics than on primary surpluses to reduce the debt ratio. The amount of debt reduction varied widely, but most achieved primary surpluses in the range of 2 to 5 percent of GDP. To generate this primary fiscal adjustment, middleincome countries tended to rely equally on revenue and expenditure measures, whereas advanced economies tended to rely more strongly on expenditure cuts, perhaps because they already had relatively high revenue ratios before the debt reduction episodes.

But most MECA countries actually ran primary deficits during their debt reductions (on average 2 percent of GDP). Consequently, these countries relied more than their peers in

\section{Chart 3}

\section{Sweat or good fortune?}

Countries relied more on automatic dynamics than fiscal adjustment in reducing their debt.

(percent of GDP)

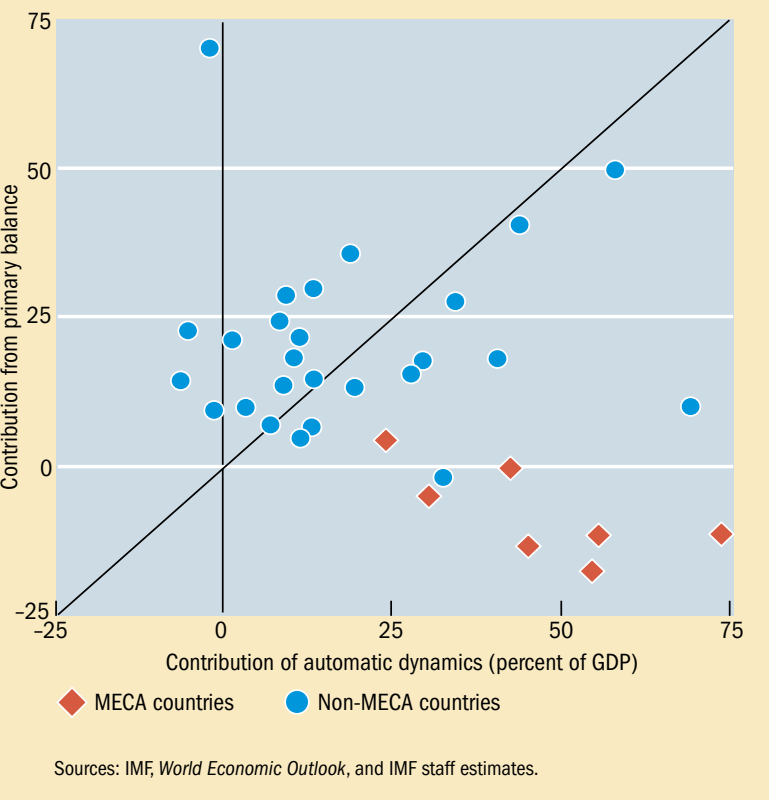

other regions on favorable debt dynamics to reduce their debt ratios (the farther southeast a country from the 45-degree line in Chart 3, the larger its reliance on automatic debt dynamics relative to the contribution of the primary fiscal balance). By contrast, advanced economies tended to rely somewhat more on primary surpluses than on automatic debt dynamics.

The tendency to rely on automatic debt dynamics rather than primary surpluses was especially pronounced among cases with higher initial debt levels, perhaps because countries that were unable to prevent large debt buildups were also less able to consolidate their finances during debt reduction episodes and hence had to rely more on favorable macroeconomic conditions. By contrast, debt reduction episodes that relied more on primary surpluses than on automatic debt dynamics tended to be more sustained. These types of episodes were also more concentrated among advanced than middle-income economies.

Some countries might be tempted to inflate their way out of debt. In principle, a country that manages to create inflation in a way that is not fully reflected in interest rates could generate favorable debt dynamics without too much adjustment of fiscal policies. But resorting to substantial inflation can mean a quick loss of credibility. Moreover, given many countries' substantial foreign currency debt, efforts to inflate out could be thwarted by ensuing currency depreciation. Indeed, few countries posted high inflation during their debt reduction episodes (only three cases had average inflation above 20 percent). And although countries with less foreign currency debt might be expected to resort to higher inflation than countries with more, there is no evidence of systematically higher inflation in countries with a lower share of foreign-currency debt.

In sum, middle-income countries other than oil exporters tended to rely on the automatic debt dynamics brought about by favorable macroeconomic conditions, rather than on primary surpluses during episodes of large debt reduction. But significant primary fiscal adjustment was needed to set the debt reduction in motion, and higher primary surpluses were associated with more sustained debt reduction episodes. This underscores the importance of fiscal adjustment not only as a direct contributor to debt dynamics but also to spur favorable macroeconomic conditions that reduce the debt-toGDP ratio. In advanced economies, automatic debt dynamics played less of a role-perhaps because their economies tend to be less dynamic - and they had to rely more on sustained fiscal effort to achieve debt reduction.

With the potential for higher world interest rates and projections for a relatively slow recovery for many countries emerging from the global crisis, more significant fiscal adjustment than in the past may be required to bring down debt. For Lebanon, further debt reduction will require adequate primary surpluses, supported by structural reforms aimed at maintaining the momentum of growth.

Harald Finger is a Senior Economist and Azim Sadikov an Economist in the IMF's Middle East and Central Asia Department. 
cally giving away something that could bring much wealth if sold on the international market.

On a global scale, as the price of oil rose from an annual average of $\$ 29$ a barrel in 2003 to about $\$ 145$ a barrel in July 2008, total oil subsidies rose from $\$ 54$ billion in 2003 to an annualized peak of $\$ 518$ billion in mid-2008, of which two-thirds were in oil-exporting countries (see Chart 1). At the same time, in the past few years demand for petroleum products has increased at double-digit rates in oil-exporting countries - much faster, even, than in India and China. By contrast, in the United States, where prices reflect market movements, gasoline prices almost tripled in the same period, from an average of $\$ 1.64$ a gallon in 2003 to an average of $\$ 3.21$ a gallon in 2008, dampening demand (see Chart 2).

\section{Costs of cheap energy}

The notion that cheap energy brings only benefits to its users is increasingly questionable. Breathing can be hazardous in the cities of oil-producing countries. And navigating the bumper-to-bumper traffic in Cairo, Caracas, Jakarta, Kuala Lumpur, Lagos, or Tehran is costly in terms of time, stress,

\section{Chart 1}

\section{Gassing up}

As the price of gas rose in recent years, energy subsidies shot up, especially in oil-exporting countries.

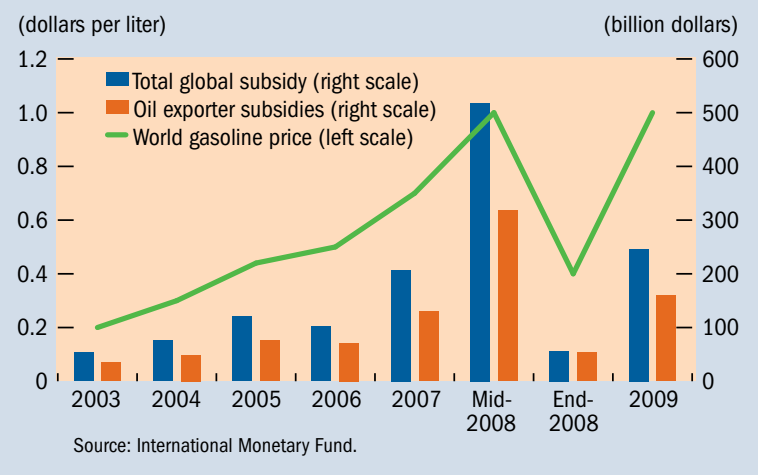

\section{Chart 2}

\section{Prices up, consumption down}

In the United States, gas consumption has fallen, even though in energy-subsidizing countries, it continues to rise rapidly.

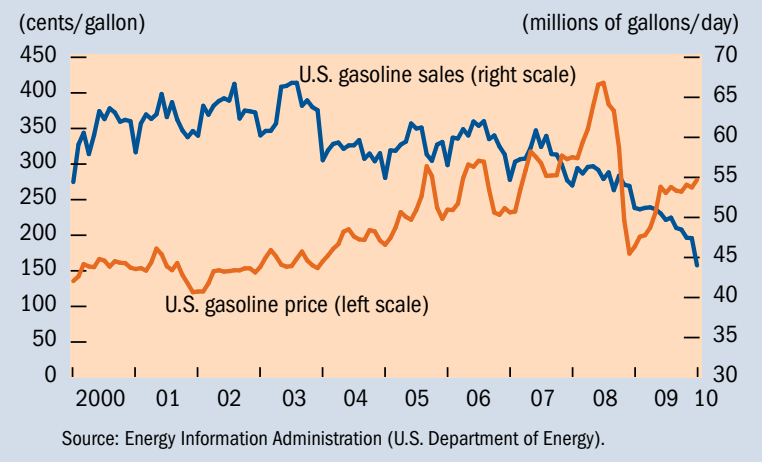

and lost productivity and income.

Claims that cheap energy promotes economic development are equally dubious. There is clear evidence that energy intensity (measured as energy use per unit of output) increases with subsidies to energy (see Chart 3). Cheap energy discourages energy saving and, in countries that produce mostly for their domestic market, impedes the production of energy-efficient goods, such as cars, that are likely to be purchased in international markets. This inability to compete internationally hampers specialization and slows economic growth and job creation. As a result, attempts to diversify the economy fail, and oil-producing countries remain even more exposed to the vagaries of international energy markets.

Finally, low energy prices can hardly be supported on social equity grounds. In the end, they benefit mainly the biggest energy users, who tend to be the richest and the most able to afford large cars and energy-guzzling appliances.

To accelerate economic growth in the non-oil sector and create jobs, policymakers in oil-exporting countries are starting to realize that they must implement reforms aimed at increasing economic efficiency and competitiveness. These reforms have garnered support from the international community. At the 2009 G-20 summit in Pittsburgh, participants said they would "rationalize and phase out over the medium term inefficient fossil fuel subsidies that encourage wasteful consumption" and asked the international financial institutions to "offer support to countries in this process." Several oil exporters are now actively considering elimination of energy subsidies.

Removing domestic energy subsidies is risky, as demonstrated by the unrest in some countries that have attempted to do so. Most people cherish their access to cheap energy, even if they are aware that this is not the best way to benefit from their national wealth. Distrust of government can run deep, too. Yet the experience of eastern European countries

Chart 3

\section{Energy use in energy-subsidizing countries}

Cheap gasoline discourages energy conservation and the production of energy-efficient products.

(thousands of BTU/dollar, 2000 price level) 40,000 -
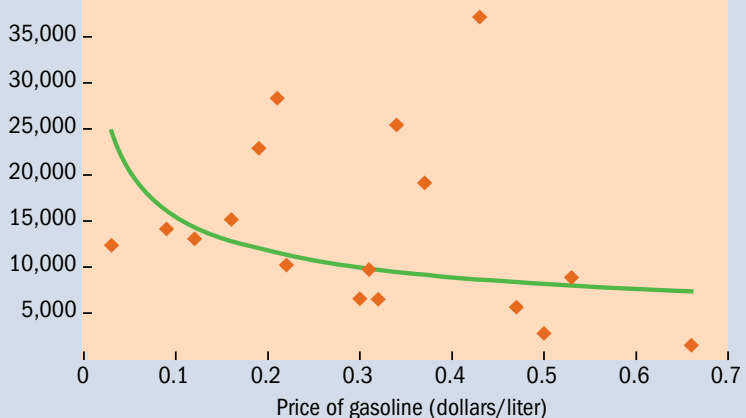

Sources: Energy Information Administration (U.S. Department of Energy) and World Bank, World Development Indicators.

Note: BTU = British thermal units. 
in the 1990s shows that energy price reform can succeed, if a number of microeconomic and macroeconomic issues are taken into account during its planning and implementation (Guillaume and Zytek, 2010).

\section{Justifying and implementing reform}

The reforms must gain broad public acceptance. A simple cash transfer program to compensate all households for the price increase is easy to implement and understand. It effectively continues to give away the national energy wealth to all citizens and yet rationalizes energy use. Alternatively, a government could try to develop targeted cash transfers. However, any program that targets some groups of beneficiaries (the poor) while excluding others (the middle class) would alienate some of the most important stakeholders in the reform.

An important, if less obvious, element of energy price reform is the adjustment of the corporate sector. A large increase in energy prices in countries where firms have benefited from very cheap energy for decades will require massive restructuring of the production sector. The transition from high- to low-energy intensity can be lengthy and turbulent, as firms cannot just walk away from their machines and products and replace them with modern, energy-efficient equipment and technology. However, evidence shows that countries that moved fast on corporate restructuring - and did so in a credible, irreversible way after liberalizing energy prices-managed to achieve the largest gains in energy efficiency. Conversely, countries where enterprise restructuring was plagued by reluctance and delays have underperformed economically, experiencing slow growth and high inflation.

The corporate sector will find the increase in energy prices credible only if energy suppliers are allowed to suspend energy deliveries to users who accumulate payment arrears. At the same time, energy users must be able to adjust their product lines and prices to allow them to pay for their energy consumption from their revenues rather than by requesting additional bank loans or government subsidies. Though the elimination of energy subsidies will push costs and prices higher, including for many staple goods, policymakers should refrain from imposing price controls to limit pass-through of the higher energy prices. Price controls would only shift losses from energy producers to commercial users. Instead, supporting measures - such as tax rebates or well-targeted cash support for corporate restructuring-could help ensure profitability while providing incentives for companies to adopt energy-efficient technology.

In addition, bank credit allocation and monitoring need to be strengthened to ensure that banks are not pushed to bail out inefficient enterprises with soft loans. Banks should keep enterprises at arm's length and preserve a strict creditordebtor relationship so that the potentially negative impact of the reform on banks' balance sheets is minimized.

\section{Macroeconomic policies}

Beyond the microeconomic considerations, energy price reform must be supported by sound and coordinated macro- economic policies. Transparent and coordinated fiscal, monetary, and exchange rate policies are needed to limit price volatility over time and related market distortions.

Specifically, in addition to redistributing to households and enterprises revenues arising from the price increase, government fiscal policies should aim at setting aside reserves to provide temporary support to socially important institutions, such as schools and health care facilities, or to the most vulnerable groups, such as people laid off as a result of the closure of large and inefficient enterprises in sectors with few employment alternatives. Without fiscal reserves, policymakers would likely be tempted, in a knee-jerk reaction to political pressure, to resort to quasi-fiscal financing through the banking system or administrative controls, such as energy delivery quotas or temporary price reductions for selected users. Either would introduce distortions in the economy and undermine reform.

Exchange rate policy poses another challenge, particularly since many oil-producing countries with large subsidies maintain fixed or heavily managed exchange rates. If the exchange rate is kept unchanged in nominal terms-especially in countries where pre-reform energy prices were at a small fraction of their international level-competitiveness will suffer and political pressure will build to increase distortionary tariffs and nontariff protections. If the exchange rate is depreciated or floated without supporting fiscal and monetary policies, confidence in the national currency may be undermined, as inflationary pressures build and dollarization spreads.

Tight monetary policy will limit the secondary effects of a price increase on the aggregate price level. But implementing monetary policy during such a reform is a challenge, especially in countries where the required price adjustment is very large. After all, such reform aims to change the entire structure of the economy.

Dominique Guillaume is a Deputy Division Chief and Roman Zytek a Senior Economist in the IMF's Middle East and Central Asia Department.

\section{References:}

Zytek, Roman, "Subsidies in the Islamic Republic of Iran," IMF Selected Issues Paper, June 2008.

D. Guillaume and R. Zytek, "The Economics of Energy Price Reform in the Islamic Republic of Iran,” IMF Selected Issues Paper, January 2010.

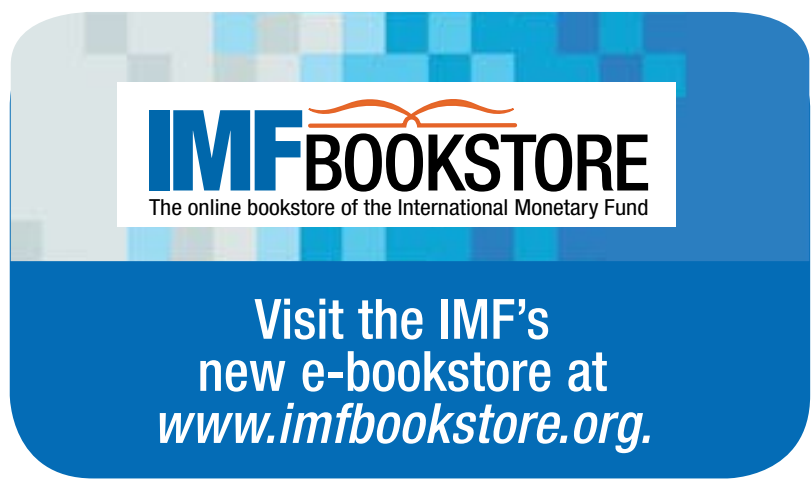




\section{이
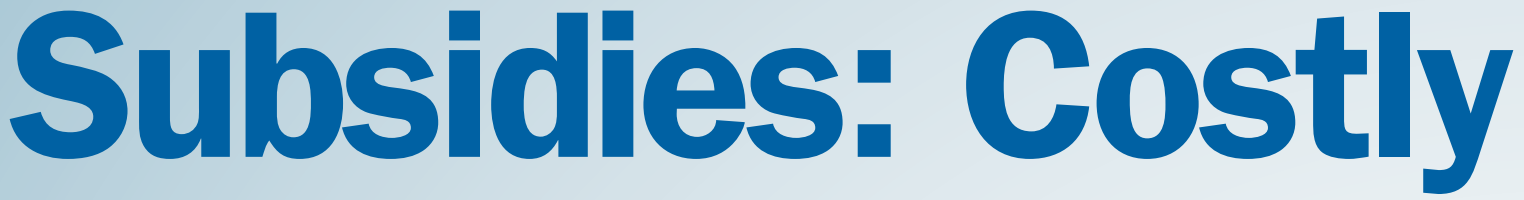

\section{Reducing subsidies worldwide can bring substantial environmental benefits and create much-needed fiscal space}

$\mathrm{P}$ ETROLEUM product subsidies have increased in recent years. In 2003, global consumer subsidies for petroleum products totaled nearly $\$ 60$ billion. By mid-2008, they had increased more than eightfold-to $\$ 520$ billion. As international fuel prices surged during this period, many governments chose not to fully pass through these increases to domestic retail prices, resulting in rising subsidies. Although subsidies fell sharply in the second half of 2008 as oil prices dropped, they increased again throughout 2009 as oil prices rebounded, and are projected to reach almost $\$ 250$ billion by the end of 2010 .

But the true economic subsidy is even higher. In principle, petroleum product prices should include taxes both to contribute to government revenue requirements and to address domestic and global environmental damage. If taxes are too low, the result is a consumer "tax subsidy." Based on a benchmark tax of $\$ 0.30$ a liter that takes these considerations into account, the global "tax-inclusive" consumer subsidy is projected to reach $\$ 740$ billion by the end of 2010 , equivalent to 1 percent of global gross domestic product (GDP).

\section{Petroleum product subsidies are increasing again with the rebound in international oil prices.}

(billion dollars)

(dollars/liter)

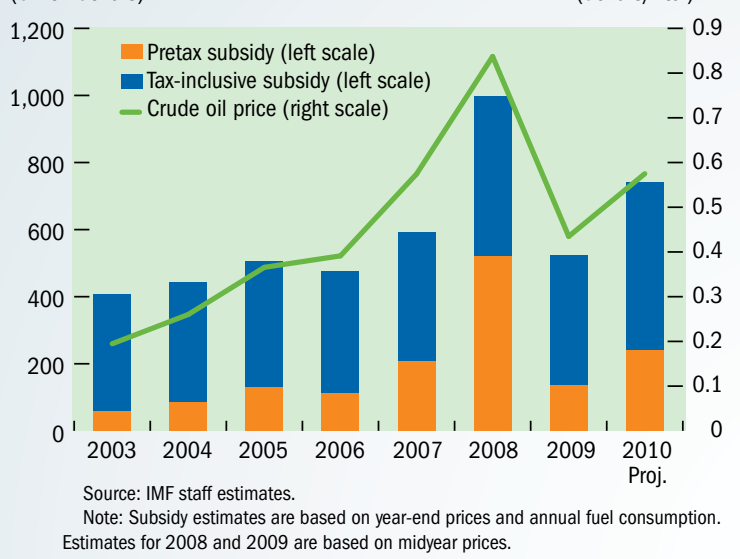

\section{Who subsidizes?}

Whereas all pretax subsidies are found in emerging and developing economies, advanced economies account for a sizable share of tax-inclusive subsidies. Of projected pretax subsidies totaling $\$ 250$ billion in 2010, emerging economies account for 65 percent, developing economies for the remaining 35 percent. Of projected tax-inclusive subsidies of $\$ 740$ billion in 2010 , emerging economies account for 57 percent, developing economies 20 percent, and advanced economies the remaining 23 percent.

\section{Emerging and developing economies account for all pretax subsidies, whereas advanced economies account for 23 percent of tax-inclusive subsidies.}

(percent of petroleum product subsidies by country group, 2010)
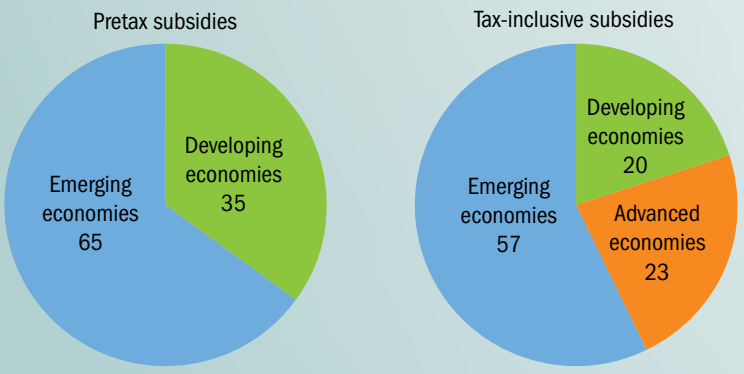

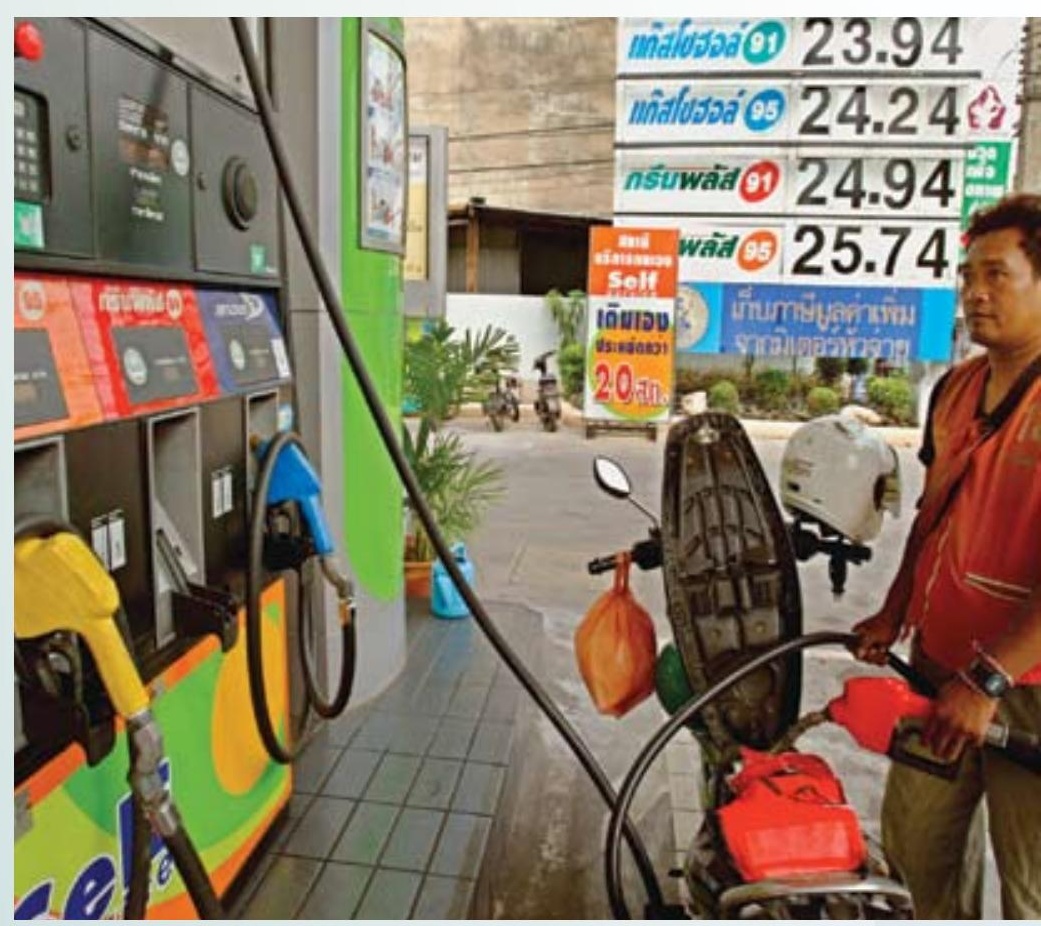

Source: IMF staff estimates. 


\section{and Rising}

\section{Who benefits?}

Although subsidies are commonly believed to help the poorest, most of the benefit actually accrues to the highestincome households, which use more petroleum products. For example, in Africa, 65 percent of all fuel subsidies go to the richest 40 percent of households. But the distribution of subsidies also differs substantially across fuel products. The benefits of gasoline subsidies are the most regressive, with more than 80 percent of total benefits going to the richest 40 percent of households.

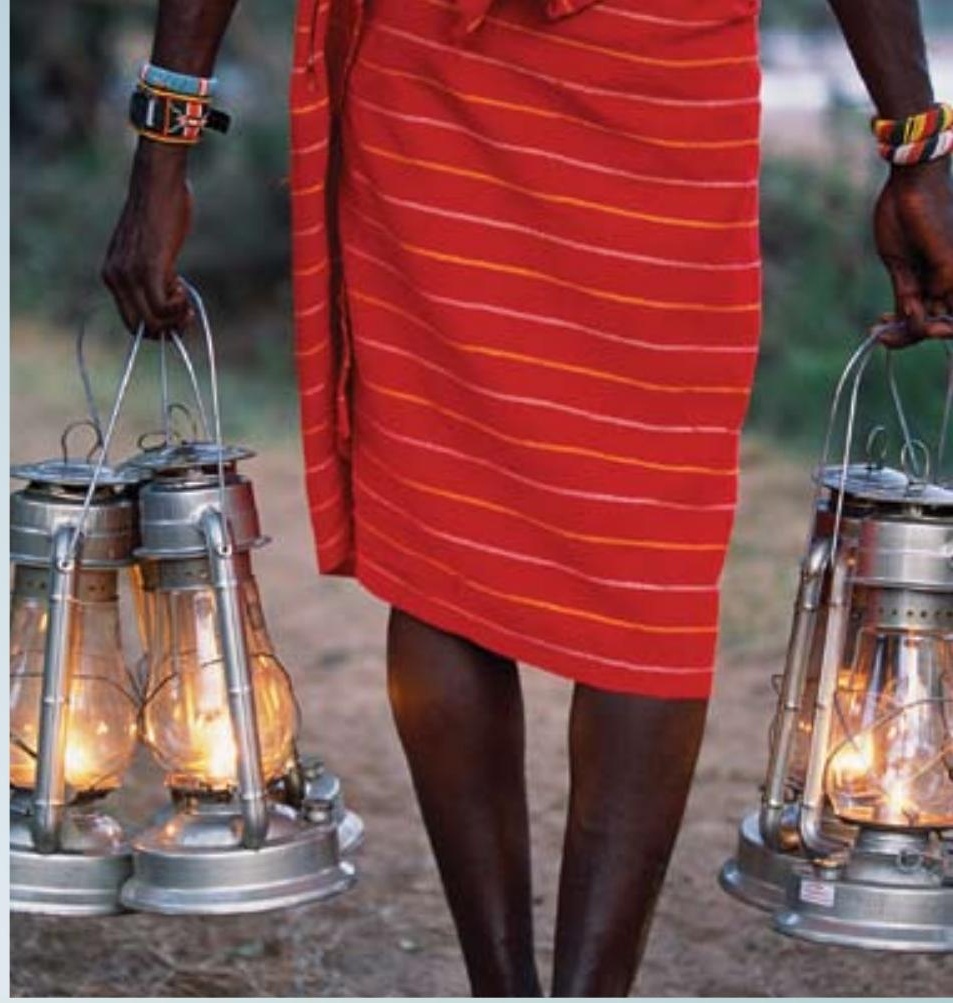

Most of the benefits from subsidies go to the richest households.

(percent of petroleum product subsidies by income group)

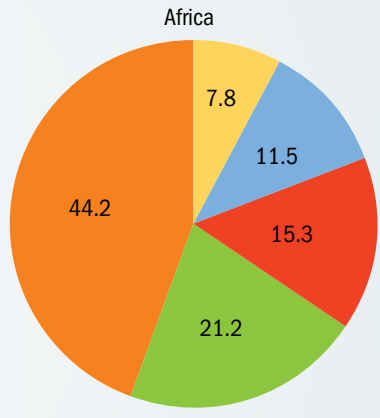

Bottom quintile

Quintile 2

Quintile 3

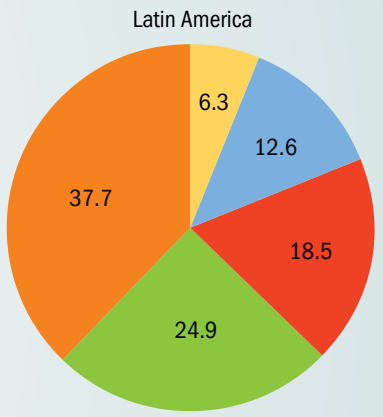

Quintile 4

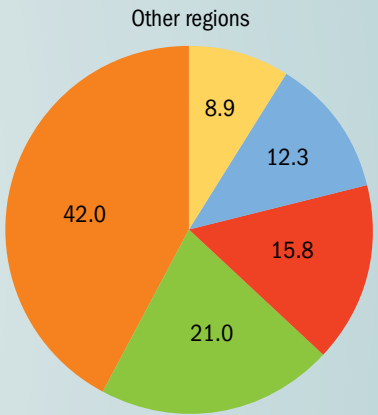

Source: IMF staff estimates based on averages of available country estimates using country-level household surveys over various years.

\section{Promoting better options}

Many countries that provided fiscal support to buffer the effects of the global economic crisis now face rising fiscal deficits. Cutting tax-inclusive subsidies in half would decrease the average projected fiscal deficit in subsidizing countries by 1 percent of GDP. In addition, a limit on subsidies could have substantial benefits for the environment: cutting subsidies by half could mean close to a 10 percent reduction in greenhouse gas emissions by 2050 .

However, the elimination of even badly targeted subsidies could seriously hurt poor households. Transfers targeted to those who are neediest would be a feasible alternative. For example, countries could eliminate gasoline subsidies while maintaining subsidies on kerosene, which is more important in poor households' budgets. In addition, some of the budgetary savings from reducing subsidies could be redirected to existing programs that better help the poor, including school meals, lowering education and health fees, and cash transfers. Improving the design of social safety net programs over time can reduce the pressure for fuel subsidies.
Public information campaigns need to emphasize that fuel subsidies are inefficient, inequitable, and costly. Transparently recording subsidies in government accounts can reinforce reform by making fuel subsidies compete with higher-priority uses of public funds. Although a liberalized market-based approach to petroleum pricing is best, countries can adopt an automatic pricing mechanism (a system that adjusts prices regularly in response to changes in international prices) while they develop a competitive supply system and effective means of regulation. Well-designed pricing mechanisms can prevent sharp retail price increases in the short term while incorporating international price changes over the medium term and managing fiscal volatility.

Prepared by Benedict Clements, David Coady, and John Piotrowski. Text and charts based on Petroleum Product Subsidies: Costly, Inequitable, and Rising, published by the IMF in 2010. The report is available at www.imf.org/external/ pubs/ft/spn/2010/spn1005.pdf 


\section{Sovereign Wealth Funds}

in the
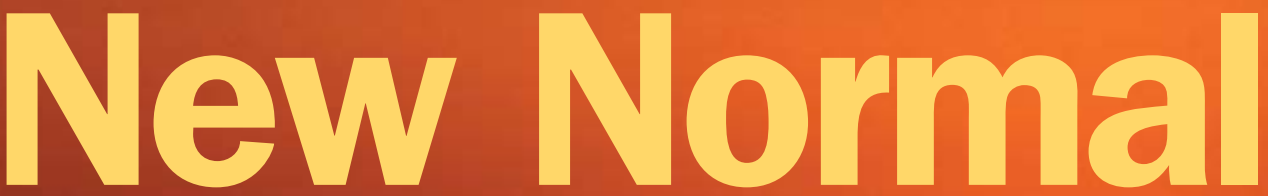

M

Petroleum plant in Jubail, Saudi Arabia.

Mohamed A. El-Erian

As the global financial crisis recedes, state-owned investment companies are well placed to seize a new set of opportunities and navigate changing risks

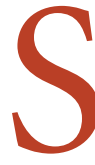
OVEREIGN wealth funds, essentially state-owned investment entities with long time horizons, are among the investors best equipped to navigate financial markets after the global crisis. Yet they too face potential challenges in steering a course through what is likely to be a multiyear, bumpy resetting of the global economy.

How sovereign wealth funds confront these challenges will speak directly to their effectiveness in investing national wealth to benefit current and future generations. It will also affect their contributions to stabilizing a fluid global economy that will experience significant multiyear changes in the systemic drivers of growth, employment, wealth, and welfare creation.

This article considers three key topics: where sovereign wealth funds stood on the eve of the global financial crisis, where they stand today, and future implications.

\section{As the crisis broke}

Three main factors defined where sovereign wealth funds stood as a group in the run-up to the most acute phase of the recent global financial crisis and the worldwide economic and sociopolitical dislocations that followed:

- Consistent with their "patient capital" characteristics and their long-term orientation, sovereign wealth funds were gradually adopting a bolder investment approach, which included taking on significantly more exposure to liquidity and equity risk.

- The funds were exhibiting greater awareness of the sensitivity in some industrial countries to foreign ownership of domestic physical assets. A manifestation of that awareness was joint agreement on a voluntary set of principles (known as the Santiago Principles) that emphasize transparent and sound governance structures, appropriate regulatory and disclosure requirements, and commercially based investment and risk-management approaches.

- They operated in a highly supportive internal environment fueled by booming domestic economic growth, continued large accumulation of international reserves, and ready availability of credit. 
Each of these factors was deemed consistent with delivering higher risk-adjusted returns over time. They also reflected the then-widespread view-held both in the private and public sectors_of a cyclical and secular "great moderation" in the economic and policy realms. "Goldilocks" (as in "not too hot, not too cold") became the one-word bumper sticker for this period.

Like virtually every sector of the financial and policy worlds, sovereign wealth funds as a whole were caught off guard by the disruption in global liquidity and funding that followed the disorderly failure of the Wall Street investment bank Lehman Brothers in September 2008. Virtually overnight, and as a cascading number of markets seized up, investors around the world were hit with dramatic repricing in all risk factors-particularly liquidity. As a result, markets around the world experienced varying, yet notable, degrees of a sudden stop.

With the global financial services sector at the center of the storm, the direct holdings of sovereign wealth funds in financial companies came under particularly intense pressure-especially as some of the funds had moved earlier to inject capital into major Western banks. Meanwhile, rather than continuing to receive large new inflows, some sovereign wealth funds found themselves under pressure to support other national (and, in some cases, regional) entities that were facing sudden and acute cash needs.

\section{Investment returns vanished}

As a result, there was a dramatic change for sovereign wealth funds during the six-month period that ended in March 2009: investment returns turned dramatically negative; cash, collateral, and counterparty management became even more acute priorities for risk management; some isolated liquidity pressures emerged; and major strategic decisions were postponed until there was greater clarity about the global financial system and where it was headed.

More generally, the seizing of global markets generally caused a pause in the longer-term evolution of asset-liability management in emerging economies - a process that had seen a number of systemically important countries and regions move steadily from delayed recognition of their improving circumstances to debt buybacks and then to more sophisticated asset management. Until emerging economies could see more clearly what the changes to the global economy might be, several of them felt it best to wait before embarking on the subsequent stages of their own evolution, which often involved major changes in how they manage their economies (including a pronounced shift away from direct controls and toward much greater reliance on indirect instruments).

Sovereign wealth funds also experienced a significant change in how they were perceived in many industrial countries. Most notably, countries that had once warned these funds against taking a direct stake in their domestic companies began actively seeking sovereign wealth fund investments to counter the highly disruptive impact of private sector deleveraging (asset shedding) at home. The tables had turned. Sovereign wealth funds were being wooed to help recapitalize struggling companies-either through new cash injections or by exchanging more senior claims on those companies for instruments lower down in the companies' capital structure.

\section{Sovereign wealth funds today}

What are the main issues sovereign wealth funds confront as the global financial crisis recedes? To answer this question calls for an explicit look at where the global economy stands and how it is likely to change.

Thanks to a massive injection of public sector capital and liquidity - undertaken in a dramatic "whatever it takes" crisis management mode, mainly in the advanced economiesthe global financial system began to normalize in 2009. Key financial markets-particularly short-term funding and liquidity management-began to function smoothly again; companies were able to regain access to new funds through bond issuance; and trust returned to a range, albeit reduced, of counterparty relationships.

The core of the global financial system has overcome the

\section{Several sovereign wealth funds}

\section{are already well on their way to formulating and implementing forward-looking asset allocations with a global focus.}

massive cardiac arrest it experienced after September 15, 2008, the day Lehman Brothers failed. That is the good news, and it has come as a result of bold and imaginative policy responses.

Yet, given the severity of the 2008-09 global financial crisis, the bold policy response was not able to offset fully the damage to other parts of the global economy. Economic growth and international trade suffered, unemployment soared, and, in a manner that marked a dramatic break from past crises, industrial countries were hit particularly hard.

The bold policy response also, and inevitably, entailed risk and unintended consequences. Noncommercial considerations started to affect the functioning and valuation of significant markets, including the mortgage-backed segment in the United States. Central bank balance sheets ballooned with assets acquired from the private sector. Public debt soared as governments spent freely and massively to prop up the economy and as tax revenues declined. These elements of collateral damage have, in themselves, become important drivers of markets and economies. Just witness what has happened in Europe, where the debt crisis morphed into regional dislocations requiring a massive policy response on the part of the European Union and European Central Bank with a major assist from the International Monetary Fund.

The global financial crisis has given way to the next phase in the multiyear, serial dislocations of balance sheets. Concerns about the private sector have been replaced by bigger wor- 
ries about public balance sheets in industrial countries-and rightly so. Sovereign risk is in play. Regulation is in flux. The integrity of key institutions is under pressure. And high levels of structural unemployment are of economic, political, and social concern.

\section{The new normal}

The massive jump in public indebtedness, in absolute terms and as a percentage of gross domestic product, is an important component of what we at PIMCO call the "new normal." And although it is too early to predict what every component of this new normal will be, certain elements are already visible.

Important changes during the next three to five years will likely include

- a reduction in the trend rate of economic growth of economies that bet heavily on the financial sector;

- persistently high unemployment in industrial countries, followed by a slower reversion to what will be a higher natural rate of unemployment-in an environment of more fragile safety nets;

- a dramatic shift in emphasis from unfettered market activities to greater government involvement;

- pronounced divergence between core countries and those on the periphery, most notably in the euro area; and

- a meaningful, regulatory-led reduction of risk both in the activities and balance sheets of banks.

Overall, the global financial crisis of 2008-09 marked a dramatic end to the great age of leverage, credit, and debt entitlement-a time when people felt entitled to make major purchases on the basis of expected income in the distant future and hopes of large price appreciation. Finance-driven economies are no longer deemed to represent a higher and more stable phase of development. And, with several systemically important emerging economies embarked on a development breakout, the world must find ways to make room for a long-term realignment of economies.

This new normal will further blur the traditional distinctions between industrial and emerging economies. It is also likely to involve a gradual shift in the analytical characterization of the United States-from an economy that operates essentially as large and closed toward one that is more open and more susceptible to developments in the rest of the world.

The global financial crisis has also undermined the standing and credibility of the Anglo-Saxon economic model that emphasizes liberalization, deregulation, interconnectivity, and unfettered markets. This model acted as an important magnet for global convergence. Given the absence of an alternative convergence magnet, greater pressures in the new normal may suspend, or even reverse, some aspects of globalization.

\section{Implications for state investors}

Together, these factors constitute an important change in the operational landscape for global investors, including sovereign wealth funds. They call for some retooling of investment strategies and risk management, as well as business and other operational strategies. They will require challenging adaptations in the optimal mix of human, technological, and ana- lytical resources and better communication with economic and political stakeholders (including political sponsors and society at large).

Sovereign wealth funds are at an advantage when it comes to managing the bumpy journey to the new normal: their stable and patient capital and long-term orientation in investment objectives put them in an excellent position to make a first move. Indeed, the question should not be whether this pool of patient capital is able to pursue a first-mover strategy_it is. The question is whether it is willing to do so. The demands on operational processes will test the responsiveness of sovereign wealth funds' governance structures, the robustness of their investment processes, and the effectiveness of their internal and external communication activities.

Governance structures will be called on to respond to a combination of cyclical and secular changes, appropriately shifting over time from "defense" to "offense."

At the most fundamental level, institutions will need clear overall guidance from their governing bodies, so managers of sovereign wealth funds can allocate their assets in a forwardlooking long-term manner anchored by solid cash, liquidity, counterparty, and collateral management.

Moreover, holistic risk-management frameworks must supplement conventional asset-class diversification with targeted and cost-effective management of tail risks-events that are rare, but that carry catastrophic consequences.

The governing bodies of sovereign wealth funds will have to rely on managers and staff armed with forward-looking analytics and technology. They must also play a more important role in protecting sovereign wealth funds from pressure to support noncommercial activities-domestically, regionally, and internationally.

Responsive structures that govern key areas of investment management cannot be built overnight. They require significant and sustained effort devoted to processes that can dynamically develop the necessary frameworks and, as a result, ensure investment decisions marked by a relatively high degree of conviction and foundation.

Superior navigation on the bumpy journey to the new normal requires, first, strong defense in the form of prudent cash, liquidity, counterparty, and collateral management. Once this is achieved, investors can pursue with more confidence opportunities that mesh well with a sovereign wealth fund's greater ability to underwrite liquidity risk factors. For example, when valuations are already disrupted, price appreciation will be consistent with the realities of the new normal, and there are identifiable short-term catalysts that accompany price appreciation, closing the valuation gap between technical and fundamental factors.

As Donald Sull (Sull, 2009) of the London Business School has admirably documented in his detailed work, positioning for the new normal also requires institutional adaptability and agility.

On paper, sovereign wealth funds outshine many other investors when it comes to their adaptability and agility. For example, lacking the home bias that forces many investors to deal largely in domestic securities, several sovereign wealth 
funds are already well on their way to formulating and implementing forward-looking asset allocations with a global focus.

These considerations should never discount the reality that sovereign wealth funds operate in a complex sociopolitical context, at home and abroad. They must, therefore, have the trust of their political sponsors and society at large. Indeed, this is crucial to the contract implicit in setting up an investment management operation in the public sector.

Communication is increasingly recognized as vital to ensuring public buy-in - in both good times and bad. The global financial crisis has highlighted the importance of establishing the proper context for politicians and others to evaluate what is taking place in the portfolios of sovereign wealth funds. This requires a higher degree of disclosure than has traditionally been the case, and several sovereign wealth funds have already stepped up their efforts in this regard.

Appropriate communication and statutory guardrails help minimize the risk that special-interest groups will improperly capture sovereign wealth funds. The key lies in greater clarity in disseminating timely information on sovereign wealth funds' objectives, overall strategy, and medium-term evaluation metrics.

\section{Retooling required}

In the aftermath of the global financial crisis, the world is in the midst of major cyclical dislocations and large secular realignments. The bumpy road to the new normal means virtually every segment of the global economy must retool.
Although sovereign wealth funds were not able to completely sidestep the global financial crisis, they have recovered nicely and are well placed as a group to navigate the journey to and through the new normal. Indeed, the patient nature of their large capital pools and the long-term nature of their objective functions are the best set of investment characteristics for virtually all global investors.

Exploiting their advantage is far from assured or automatic. Success requires continuous improvement in the institutional responsiveness of sovereign wealth funds to challenges in the areas of governance, investment processes, and communication.

Such improvements are not easy to deliver. They may take some sovereign wealth funds out of their operational comfort zone, and they involve risk. Yet, given the scale of ongoing and prospective changes in the global economy, the alternative of backward-looking business as usual would be even riskier.

Mohamed A. El-Erian is Chief Executive Officer and co-Chief Investment Officer of the global investment management company PIMCO. This article expresses the opinions of the author, but not necessarily those of PIMCO.

Reference:

Sull, Donald, 2009, The Upside of Turbulence: Seizing Opportunity in an Uncertain World (London: Harper/Collins Press).

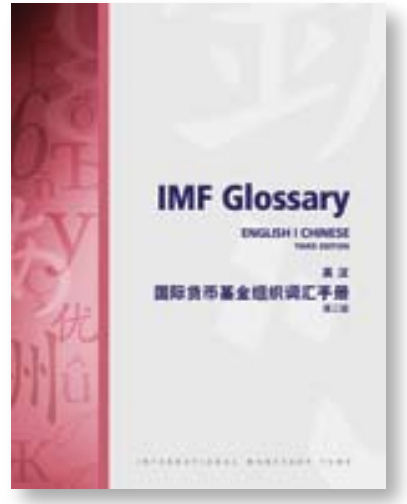

\section{IMF Glossary: English-Chinese, 3rd Edition}

by the IMF's Bureau of Language Services

IMF glossaries contain the most useful terms for translators dealing with IMF material. The main body of each glossary consists of terms, phraseological units, and institutional titles covering areas such as macroeconomics, money and banking, public finance, taxation, balance of payments, statistics, accounting, and economic development. IMF glossaries contain terminology relating to the IMF's organization and operations, as well as from the Articles of Agreement, By-Laws, Rules and Regulations, and other major IMF publications. 


\section{BACK TO BASICS}

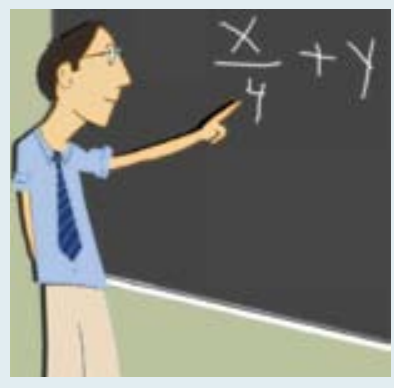

Supply and Demand

\section{When buyers and sellers get together, the key outcome is a price}

Irena Asmundson

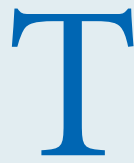

HREE little words. Often that is all it takes to make one's heart beat faster. "Liberty, equality, fraternity" captured the French Revolution. "I love you" underpins many a successful relationship. "Life, liberty, happiness" are at the heart of the U.S. Declaration of Independence. For many economists, those three magic words are "supply, demand, price."

In any market transaction between a seller and a buyer, the price of the good or service is determined by supply and demand in a market. Supply and demand are in turn determined by technology and the conditions under which people operate. At one extreme, the market could be populated by a large number of virtually identical sellers and buyers (for example, the market for ballpoint pens). At the other extreme, there might be only one seller and one buyer (as would be the case if I want to barter my table for your quilt).

\section{Perfect competition}

Economists have formulated models to explain various types of markets. The most fundamental is perfect competition, in which there are large numbers of identical suppliers and demanders of the same product, buyers and sellers can find one another at no cost, and no barriers prevent new suppliers from entering the market. In perfect competition, no one has the ability to affect prices. Both sides take the market price as a given, and the market-clearing price is the one at which there is neither excess supply nor excess demand. Suppliers will keep producing as long as they can sell the good for a price that exceeds their cost of making one more (the marginal cost of production). Buyers will go on purchasing as long as the satisfaction they derive from consuming is greater than the price they pay (the marginal utility of consumption). If prices rise, additional suppliers will be enticed to enter the market. Supply will increase until a market-clearing price is reached again. If prices fall, suppliers who are unable to cover their costs will drop out.

Economists generally lump together the quantities suppliers are willing to produce at each price into an equation called the supply curve. The higher the price, the more suppliers are likely to produce. Conversely, buyers tend to purchase more of a product the lower its price. The equation that spells out the quantities consumers are willing to buy at each price is called the demand curve.

Demand and supply curves can be charted on a graph, with prices on the vertical axis and quantities on the horizontal axis. Supply is generally considered to slope upward: as the price rises, suppliers are willing to produce more. Demand is generally considered to slope downward: at higher prices, consumers buy less. The point at which the two curves intersect represents the market-clearing price-the price at which demand and supply are the same (see chart).

Prices can change for many reasons (technology, consumer preference, weather conditions). The relationship between the supply and demand for a good (or service) and changes in price is called elasticity. Goods that are inelastic are relatively insensitive to changes in price, whereas elastic goods are very responsive to price. A classic example of an inelastic good (at least in the short term) is energy. Consumers require energy to get to and from work and to heat their houses. It may be difficult or impossible in the short term for them to buy cars or houses that are more energy efficient. On the other hand, demand for many goods is very sensitive to price. Think steak.

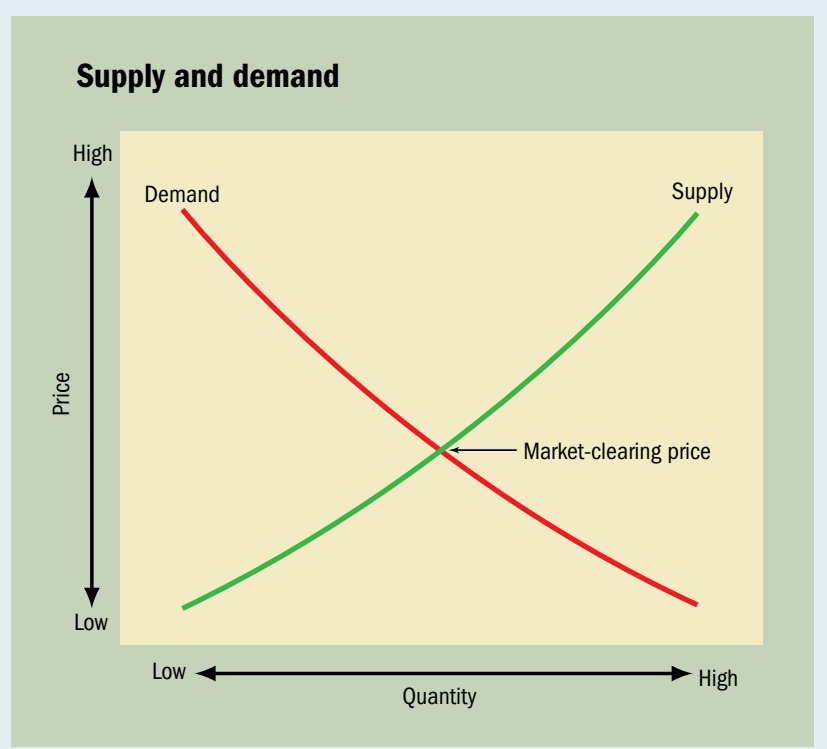


If the price of steak rises, consumers may quickly buy a cheaper cut of beef or switch to another meat. Steak is an elastic good.

Of course, most markets are imperfect; they are not composed of unlimited buyers and sellers of virtually identical items who have perfect knowledge. At the other end of the spectrum from perfect competition is monopoly. In a monopoly, there is one supplier of a good for which there is no simple substitute. The supplier does not take the market price as a given. Instead, the monopolist can set it. (Monopoly's twin is monopsony, in which there is only one buyer, usually a government, although there may be many suppliers.)

\section{Barriers to competition}

In monopoly situations, there usually is a barrier-natural or legal-to potential competitors. For example, utilities are often monopolies. It would be inefficient for two water companies to manage watersheds, negotiate usage rights, and lay pipes to households. But consumers have no choice except to buy from the monopolist, and access may be unaffordable for some. As a result, governments usually regulate such monopolies to ensure that they do not abuse their market power by setting prices too high. In return for allowing a company to operate as a sole provider, there may be requirements for minimum services to be provided to everyone or a cap on the prices that can be charged. These caps generally allow companies to recover fixed costs.

Monopolists cannot be oblivious to demand-which, as under perfect competition, varies, depending on price. The difference is that a producer in perfect competition fulfills only a portion of total demand, whereas the monopolist benefits from the demand curve of the entire market. So the unregulated monopolist can decide to produce a quantity that maximizes its profit-almost always at a higher price and in a smaller amount than in a perfectly competitive market.

In perfect competition a firm with lower costs can reduce its price and add enough customers to make up for lost revenue on existing sales. Suppose a firm earns 5 cents a unit selling 1,000 units-or $\$ 50$ - in a total market of 100,000 units. If it lowers its price by 1 cent and gains an additional 1,000 units in sales, its profits will be $\$ 80$ on its new level of sales of 2,000 units.

\section{Just one seller}

But a monopolist controls all the sales-in this case 100,000 units at a nickel a share, earning a profit of $\$ 5,000$. Lowering the price might increase total sales, but likely not enough to offset revenue lost on existing sales. Say it lowered the price (and profit per sale) by a penny, resulting in increased demand of 1,000 units. That would add $\$ 40$ to revenues. But the monopolist would also lose a penny in profit on each of the 100,000 units it had been selling-or $\$ 1,000$.

The key outcome of a monopoly is prices and profits that are higher than under perfect competition and supply that is often lower. There are other types of markets in which buyers and sellers have more market power than in perfect competition but less than under a monopoly. In those cases, prices are higher and production is lower than in cases of perfect competition.

Supply and demand can also be affected by the product itself. In perfect competition, all producers make and buyers seek the same product-or close substitutes. In a monopoly, buyers lack easy substitutes. Variety, though, allows for substitution across types. For example, the market for tomatoes involves more than simply matching buyers and sellers of an idealized tomato. Consumers may want different types, and producers can respond. Market entrants could compete head to head with an existing producer by applying the same pro-

\section{The key outcome of a monopoly is prices and profits that are higher than under perfect competition and supply that is often lower.}

duction technology, but they might instead introduce new varieties (cherry, beefsteak, heirloom) to cater to different tastes. As a result, producers have limited market power to set prices when markets are competitive but products are differentiated. Still, varieties of products can be substituted for one another, even if imperfectly, so prices cannot be as high as in monopolies.

\section{A temporary monopoly}

Complications arise when the main features distinguishing one product from another are expensive to create but cheap to imitate-for example, books, drugs, computer software. Writing a book can be difficult, but printing a copy has a low marginal cost. Consumers may buy many books, but if one becomes popular, competitors will have an incentive to undercut the publisher and sell their own copies. To allow the author and publisher to recoup fixed costs, governments often grant a temporary monopoly on that book (called a copyright) for the author and publisher. The price exceeds the marginal cost of production, but the copyright motivates authors to keep writing and publishers to produce and market books-ensuring future supply.

The market structures discussed here are a few of the ways supply and demand can differ according to context. Production technologies, consumer preferences, and difficulties in matching sellers with buyers are some of the factors that influence markets, and all play a role in determining the market-clearing price.

Irena Asmundson is an Economist in the IMF's Strategy, Policy, and Review Department. 
sharply, stock prices fell precipitously, and interbank markets dried up. Banks in advanced economies came under severe liquidity pressure and virtually stopped new lending or even shed assets. Parent banks continued to roll over outstanding credit lines to their subsidiaries, but they no longer provided additional funds, limiting new credit to what could be financed from increases in local deposits. Other capital inflows to the region declined as well, although not as sharply.

The decline in capital inflows caused a sharp drop in domestic demand. In many cases, new credit came to a virtual halt. Domestic demand contracted most in countries that previously had the biggest increases in domestic demand, the largest current account deficits, and the highest rises in credit-to-GDP ratios. In countries without large imbalances, domestic demand held up better.

The recession was exacerbated by a drop in exports. Emerging Europe's principal trading partners were also in recession. With domestic demand and exports shrinking, the GDP decline in many countries far exceeded that in previous crises.

\section{Stabilization}

Still, the total financial and economic meltdown some had feared was averted. There were no banking panics, andunlike in many advanced economies-governments did not have to step in to save entire banking systems. Nor was there a collapse of any fixed exchange rate regimes-which often happened in earlier crises in emerging economies.

Much of this was due to decisive domestic policy actions, but international support played an important stabilizing role. In several countries, the IMF stepped in-joined by the European Union (EU) in EU member countries. Other international financial institutions such as the World Bank and the European Bank for Reconstruction and Development were part of the program, and in some cases there were also financing commitments by other European countries. The private sector also contributed. Agreements with western European banks ensured continued lending to eastern European countries.

\section{The way ahead}

Eastern Europe seems poised for recovery. Exports are rebounding and domestic demand is showing signs of stabilizing. The IMF predicts the region will grow by 3.3 percent in 2010 .

Still, emerging Europe cannot return to business as usual. Future growth-especially in countries that had built up large imbalances during the boom-must rely more on capital flows into the tradables sector and less on flows into the nontradables sector. In these countries, exports are recovering, but domestic demand will likely stay weak as consumers continue to rein in spending to pay off debt.

Private sectors in countries that experienced the boom must develop new markets for exports of manufactured goods and services, which will require restructuring of their economies. That is no mean task, but it is achievable. Restructuring will be helped by market signals that will change as profits in the nontradables sector shrink and investments seek more promising venues. But the process may be difficult. Even in the tradables sector, new projects may have to fight for much scarcer financing. Inflows will remain reduced as western banks struggle to rebuild their balance sheets and riskadjusted returns in emerging Europe seem less attractive.

But public policies can play a role as well in steering eastern Europe toward a more sustainable growth path. More balanced macroeconomic policies and wage restraint can help prevent the overheating that pulls resources from the tradables to the nontradables sector. Fiscal policy in particular could play a much more active role-saving money when revenues are growing instead of increasing spending and boosting public wages. This may mean that during boom times small fiscal surpluses are not sufficient-that large surpluses are needed. Policymakers may prefer to spend in boom times, but the payoff of saving is that a large fiscal buffer will reduce the need to cut expenditure sharply during a recession-as several countries had to do during this crisis.

Preventing overheating is important, because manufacturing competitiveness in many emerging European economies deteriorated during the boom. For example, according to EU data, Latvia's unit labor costs in manufacturing rose 90 percent relative to its trading partners between 2003 and 2008. Some other countries—notably Bulgaria, Estonia, and Romania-also experienced a sharp appreciation of their real exchange rate.

Tighter fiscal policy will help moderate wage growth. Over time, wages will catch up with those in western Europe. But if the catch-up goes hand in hand with productivity increases in manufacturing, it need not impede competitiveness nor discourage investors.

\section{Increasing quality}

But emerging Europe should not compete on low wages alone - and will find it difficult to do so. Other emerging markets have even lower wages now and, as workers emigrate to western Europe, wages will rise in emerging Europe. Instead, the region should aim to produce increasingly sophisticated products. Structural reforms, including those that bolster the business climate, could help, as would improving education and, in some nations, fighting corruption.

Foreign capital inflows can also play an important role, if they are aimed at enhancing supply, especially in the external trade-oriented sector. Such investment would support growth, transfer technology, and help contribute to an improvement of labor force skills.

Some countries in the region are already following this model. In the Czech and Slovak Republics, growth during the boom was much more balanced, credit growth more restrained, and current account deficits small-and exports played an important role. Although this strategy produced growth more muted than in some of their neighbors before the crisis, their recessions were much less deep. As a result, over a longer horizon, these two countries have grown faster than countries that had a domestic demand boom.

Bas B. Bakker is a Division Chief and Anne-Marie Gulde a Senior Advisor in the IMF's European Department. 


\section{To Profit or Not to Profit: Is That the Question?}

Muhammad Yunus

\section{Building Social Business}

The New Kind of Capitalism That Serves Humanity's Most Pressing Needs

Public Affairs, New York, 2010, 226 pp., \$25.95 (cloth).

$\mathrm{T}$ The poor are disconnected:

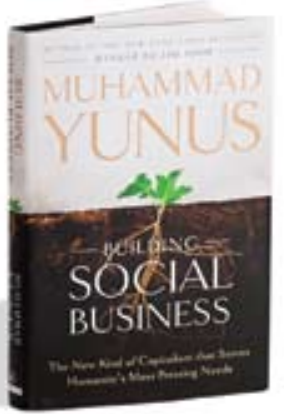
from gainful employment, access to clean water, electricity, roads, transportation, calories and micronutrients, health care, education, banking, telecommunications, the Internet, justice, security. Their willingness to work remains the largest wasted resource on earth.

Connecting the poor to opportunity can be self-sustaining. More productive work will enable them to buy solutions to the challenges they face and bring them financial self-sufficiency. Moreover, these solutions involve jobs the poor can do themselves. Prosperity is thus an autocatalytic process: work creates wealth that can then be appropriated by those who work.

Building Social Business is full of examples of business ideas to overcome poverty by enhancing the value of the poor's willingness to work and by designing effective and self-sustaining solutions to their most pressing problems. (The author is the founder of Grameen Bank-one of the first microfinance organizations. Since the late 1970s it has been making small loans to entrepreneurs in some of the poorest areas of his native Bangladesh. Its lending activities now extend worldwide.) In this, his most recent publication, Yunus shows how child malnutrition can be addressed by hiding crucial micronutrients in a pleasantly flavored yogurt (Grameen Danone); how affordable shoes for the

rural poor (Grameen Adidas) combat worm infections; how health services can be offered for a prepaid fee or cataract surgery for those who are losing their eyesight (Grameen Health Care).

This book is not just inspirational. It aims to create and brand a new social movement based on an entrepreneurial and self-sustaining way of addressing the problems of the poor, clearly distinguished from charity or from corporate social responsibility, neither of which is self-sustaining. But he also wants to distinguish it from garden variety capitalism — hence the book's subtitle. The point is not just to build businesses that address the problems of the poor, but to create "social businesses," where "everything is for the benefit of others. It is built on the selfless part of human nature."

Yunus carefully distinguishes his new brand of capitalism, and his enemy is the profit motive, which he says sooner or later gets in the way of serving the poor. He believes it should be banished. Just as a smoker who

\section{Between the Cracks}

A remarkable feature of the financial crisis is the sheer number of things that went wrong and the large number of people and institutions that made mistakes. (In Washington, D.C., the previous sentence would likely be posed as the question, who do we blame?) Former IMF chief economist Raghuram G. Rajan, of the University of Chicago Booth School of Business, in his new book, Fault Lines, brings together and explains the diverse failings that contributed to the crisis- the fault lines, as he puts it, that were exposed by the events of the past several years. Rajan then puts forward broad policy recommendations to ward off a future problem. Some of them, such as rectification of global imbalances, are familiar conventional advice, but others, such as an improved social safety net, are novel in the context of the crisis.

The book covers a broad group of such fault lines-indeed, this is virtu-

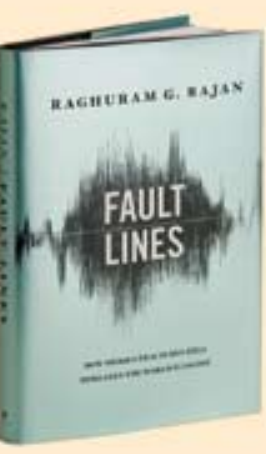

\section{Raghuram G. Rajan}

\section{Fault Lines}

How Hidden Fractures Still Threaten the World Economy

Princeton University Press, Princeton

and Oxford, 2010,

272 pp., \$16.95 (cloth)

ally a treatise on recent macroeconomic policy issues. The problems include excess leverage and overuse of credit by Americans, global savings and capital flows imbalances, loose monetary policy, financial innovations that led to a lack of transparency, faulty compen- sation plans, poor lending standards, failures by the rating agencies, and inadequate government supervision of banks-and more. Rajan has particular credibility, given that in 2005 he was an outspoken voice for caution about the potential dangers of financial innovation.

Rajan adds political economy factors to the list of explanations for the crisis. He sees the spread of credit and increased household leverage as a driving force in reaction to widening inequality in the United States. Unless they were highly skilled, families suffered from stagnant incomes, which they made up for by overextending themselves.

Political factors also contributed to the overuse of leverage. In Rajan's view, the relatively weak safety net in the United States makes politicians especially keen to avoid a weak job market and thus trigger-happy with fiscal and monetary stimulus. Problematic policies, according to Rajan, include both 
wants to quit must avoid even one puff or a Muslim during Ramadan must forgo the smallest snack, businesses must turn their back on profit. "Making a complete break from the for-profit attitude creates a huge and important difference for the businessperson who really wants to commit himself or herself to social change."

Yunus claims to have invented a new form of social organization in the realm of not-for-profit businesses geared toward solving the problems of the poor. He is careful to distinguish it from for-profit capitalism, cooperatives, socialism, government, charity, communism, or corporate social responsibility. He claims intellectual property rights on microcredit, although Accion International preceded his Grameen Bank by more than a decade. With an intelligent mix of donations and profit motive Accion created organizations such as Compartamos, MiBanco, and BancoSol, which have grown much more dynamically than Grameen Bank, precisely because, unlike Yunus, they

the extended period of exceptionally low interest rates following the economic slowdown of 2000-03 and ongoing policies such as hidden government subsidies to Fannie Mae and Freddie Mac before they were placed into conservatorship by the U.S. government in September 2008. Easy monetary policy and the implicit guarantee on Fannie and Freddie debt contributed to excessive borrowing and the housing bubble and thus to financial sector fragility and the crisis. The second half of the book discusses reforms to prevent these problems, including changes to financial regulation and to market structures such as compensation incentives.

Notable among Rajan's proposed solutions is a more effective social safety net in the United States that would reduce the fear of recession and head off unduly stimulative policies that engender bubbles. If workers - that is, voters-were less worried about job loss and dislocation, politicians might have more leeway to avoid risky poli- did not insist on group lending or oppose profits.

The not-for-profit brand does buy goodwill. Grameen has partnered with major corporations such as Danone (for the yogurt) and Adidas (for the shoes), whose association with Grameen has been good for their own brand. However, as things stand, these companies are limited to quaint programs managed by their corporate social responsibility departments. New billion-dollar markets would be transformational for the poor. Avoiding the profit motive restricts these solutions from truly scaling up, and passing up donations limits subsidization of activities that cannot be organized in a sustainable way.

Readers are likely to find inspiration, but should take the social movement Yunus is trying to brand with a pinchor a pound_-of salt.

Ricardo Hausmann

Director of the Center for International Development and Professor of the Practice of Economic Development at Harvard University

cies. Some say the crisis resulted from policies during 2000-03 that tried to compensate for a collapsed high-tech bubble by creating a bubble in housing. The recently enacted health care legislation in the United States would fit Rajan's broad recommendation for an improved safety net. As the health care law takes effect, it will be interesting to see if it affects Americans' sense of financial security and the direction of public policy.

Looking further ahead, Rajan focuses on better education and training to deal with the root causes of inequality. Improved skills will mean better job opportunities and higher incomesand less anxious policymaking to pump up economies.

Rajan's book takes a comprehensive look at what got us into the crisis and offers an intriguing approach to avoiding another one.

Phillip Swagel

McDonough School of Business, Georgetown University

\section{In the Eye of the Storm}

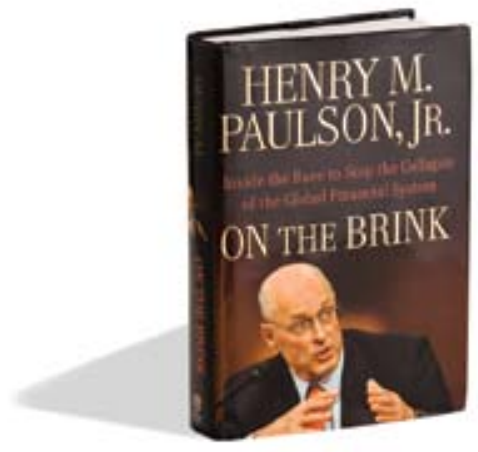

Henry $M$.

Paulson, Jr.

\section{On the Brink}

Inside the Race to Stop the Collapse of the Global Financial System

Business Plus, New York, 2010,

496 pp., \$28.99 (cloth).

$\mathrm{T}$ he failure of Lehman Brothers triggered a run on the global financial system. A sharp reduction in credit availability set off a severe global economic downturn. In the United States, the downturn led to 10 percent unemployment, a 3.7 percent drop in real GDP, and a 15 percent decline in industrial production. Henry Paulson's book addresses a number of key questions raised by the collapse of the global financial services firm: why was the disorderly failure of Lehman Brothers allowed to happen? Did the authorities anticipate the risks and, if so, could they have intervened? If early intervention was impossible, could the authorities have bailed out Lehman at the last moment, as they did another investment bank, Bear Stearns, six months earlier or insurance giant AIG the following day?

Paulson was U.S. Treasury Secretary from July 2006 to January 2009: for two years in the run-up to the crisis and during the four months of initial response. This book describes that experience.

\section{A primer of the financial crisis}

The narrative offers a historical primer. Key mileposts range from the start of the credit turmoil in August 2007 and the failure of Bear Stearns in March 2008, through the conservatorship (nation- 
alization) of government-sponsored enterprises (GSEs) Fannie Mae and Freddie Mac, to the collapse of Lehman Brothers on September 15, 2008 and the rescue of AIG the following day. The book also covers the policy response, notably Troubled Asset Relief Program (TARP) legislation-budgetary authority to purchase bad assets and inject equity into banks and the creation of numerous Federal Reserve facilities designed to provide liquidity for a distressed financial system.

Although the primer is useful, the book's unique contribution lies in the insider's view of the policy process surrounding the crisis. Four important issues-lessons for the future on making financial stability and crisis-resolution policy more effective-stand out.

\section{Learning the lessons}

The undesirable implications of segmented financial regulation make up the first lesson. Although the U.S. Treasury had overall responsibility for domestic finance, it could not override the operational independence of sectoral regulators. This complicated macroprudential supervision: strikingly, the news of major insurer AIG's significant distress reached the Treasury Secretary only days before its collapse, which undermined financial stability policy. Paulson recalls how the regulator of GSEs was reluctant to acknowledge their extreme undercapitalization and impose conservatorship. Similarly, he describes how the specialized regulator responsible for the troubled thrift (savings and loan) institution Washington Mutual elected to have it recapitalized-preserving its authority over the institution—-rather than see it sold to a stable bank, JPMorgan. Six months later Washington Mutual became the largest U.S. bank failure in history.

The second lesson concerns the importance of the legislature in shaping financial policy. Paulson describes how Congress was loath to acknowledge the accumulation of financial vulnerability in the run-up to the crisis, partly because of the financial sector's considerable political influence, especially the clout of GSEs-“"the toughest street fighters in Washington." These observations are mirrored in recent academic literature linking political contributions to congressional votes on economic issues.

The third lesson relates to the complexities of international coordination in crisis management. It is generally acknowledged that the resolution of international banks is probably the weakest link in current global financial stability frameworks. The failure of Lehman Brothers is a case in point. The investment bank had a globally integrated business, yet its international subsidiaries had to file for bankruptcy under the rules of their respective jurisdictions. In bankruptcy, Lehman's London administrator, PricewaterhouseCoopers, froze all the firm's U.K. assets, including third-party collateral from customer accounts. That action shook investors' confidence, even in jurisdictions where customers' investment bank accounts were segregated and protected in bankruptcy, such as in the United States. Paulson describes how an unforeseen idiosyncrasy of bankruptcy rules was one of the triggers of the global financial system ruin: "Suddenly everyone felt increasingly wary of dealing with any counterparty, no matter how sterling its reputation or how long a relationship one firm had with another."

In describing the failure of Lehman, Paulson keeps returning to the gaping holes in the U.S. regulatory framework - the fourth lesson. Procedures for winding down commercial bank operations are well defined by the Federal Deposit Insurance Corporation Improvement Act, but there was no comparable authority for investment banks, insurance companies, and large hedge funds. The government could not intervene by injecting more capital if one failed, even in the event of systemic consequences. The Federal Reserve could in theory make an emergency loan to any institution, but only if the loan was "secured to its satisfaction," meaning there was only minimal risk of credit losses. So why was Lehman allowed to fail while Bear Stearns and AIG were saved? Paulson maintains that Lehman's genuine lack of collateral it could have pledged to the government in exchange for rescue distinguished it from other institutions. This analysis remains controversial, but Paulson's view from the center of the breaking crisis provides an important perspective.

Lev Ratnovski

Economist, IMF Research Department

\section{Who's Afraid of Big Bad Banks?}

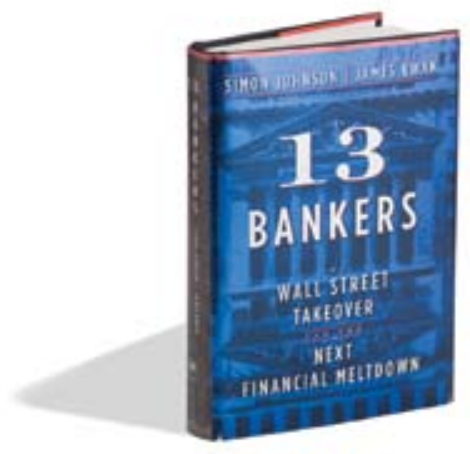

Simon Johnson and James Kwak

\section{Bankers}

The Wall Street Takeover and the Next Financial Meltdown

Pantheon Books, New York, 2010, 320 pp., \$26.95 (cloth).

\section{CC ur goal today is to change the conventional wisdom about enormous banks."}

That's the authors' conclusion toward the end of their highly readable and provocative book. At the heart of the text is a question that is perplexing economic policymakers-what will it take to make the financial system safer and steer clear of a repeat of the enormous public intervention that was necessary to prevent a collapse of the financial system? The authors target the predicaments created by financial institutions that are considered too big to fail. The moral hazard problems are well known, and Johnson and Kwak suggest that a sinister undercurrent is at play-bordering on corruption of the political and institutional mechanisms that have shaped the development of, and exercised oversight over, global financial systems- and it favors large financial institutions. 
The authors tell a good story, one that features its fair share of villains and a hero here and there. Foremost among the villains are the major banking institutions. The book portrays them as the new oligarchs. They wield excessive economic power and political influence and have reaped the benefits of their too-big-to-fail status, all the while taking excessive risks with the expectation that the taxpayer will bail them out. The popularity and support for economic liberalization, the revolving door culture that propels people of influence from the public sector to major financial institutions and back again, and the presence of a few people in key positions at the U.S. Treasury and Federal Reserve helped grease the wheels of exploitation. The IMF is not spared in this critique.

However, the authors would do well to acknowledge that many of the villains were at one time considered heroes in handling earlier financial crises and helping promote strong economic growth. No one would deny that there were mistakes along the way, and if we could scroll back and replay history, it's certain that some decisions would be retracted. The decision highlighted in the book on the regulation of over-the-counter derivative transactions is a case in point. The book suggests that these decisions may reflect the ability of the powerful self-interest of a few to sway the many, but they may have simply been the consequence of poor judgment and ignorance-we are wiser after the fact.

The timing of the book's publication couldn't have been better. Policymakers the world over have been debating how best to reform the regulatory framework for global finance, and detailed regulatory reforms are now in the works. What makes 13 Bankers valuable is its independent perspective. A central thesis of the book is that almost everyone involved in financial regulation is captured by the nature of the process and is likely to angle the reforms in favor of major financial institutions. This argument, if true, would not augur well for achieving fundamental reform that would lead to lasting improvements. The jury is still out, and there is no doubt those responsible for crafting the reforms will challenge the authors' views.

The last section of the book, which proposes solutions, is the least devel- oped, and that's too bad, because this is the part that could influence the policy debate. The authors favor hard limits on the size of financial institutions, prohibiting them from exceeding a certain percentage of gross domestic product. They propose even stricter limits on the size of more risky institutions. These limits would be added to the numerous other regulatory initiatives that are under consideration (on capital, liquidity, etc.). However, the book does not go into detail on the pros and cons of using size limits instead of (or in addition to) proposals to deal with systemically important institutions by imposing systemic risk charges, placing limitations on proprietary trading, and enhancing the resolution mechanisms for large institutions. How to formulate the proposed size limits and what to cover are not addressed. More in-depth analysis and discussion of these issues would have enhanced the operational value of this stimulating book and strengthened the case for including the recommendations as part of the reforms.

R. Barry Johnston

Assistant Director

IMF Monetary and Capital Markets Department

\section{New Crisis, Old Problems}

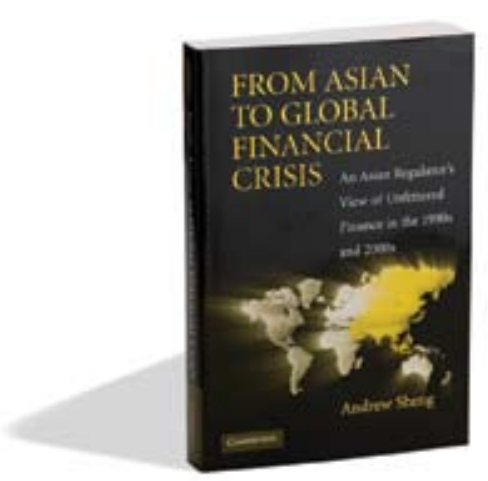

Andrew Sheng

From Asian to Global Financial Crisis

An Asian Regulator's View of Unfettered Finance in the 1990s and 2000s

Cambridge University Press, Cambridge, United Kingdom, 2009, 204 pp., \$26.99 (paper).
A ndrew Sheng's new book has 1 answers most. Sheng's experience in the West and East, coupled with his background as a Hong Kong financial regulator and scholar, set the stage for this deep, broad analysis of the financial crisis, seen through Asian eyes.

Unlike many analysts, Sheng injects a personal perspective that touches on comparative history, macroeconomics, and microeconomics and sets the book's framework. In my experience as an Asian journalist, I have never read a clearer nor more complete story of the 1990s Asian financial crisis, nor a more convincing analysis of the intrinsic links between that period and the current global crisis. But some readers may find Sheng's coping with the crisis as a regulator more interesting than his theoretical explanations.

Sheng shows how and why current tools and institutional structures are outdated. Among the most important topics he tackles: the relationship between financial intermediaries and regulators or governments. In his view, unfettered finance is at the core of these crises.

But the real picture is far more complex. Governments tend to over- and underregulate the financial sector simultaneously. This is especially true in Asia, the author says. The financial system needs not more but better regulation.

"Regulatory cycles must include constant reviews of outcomes against objectives. These reviews must examine how the strategy, priorities, incentives, standards, structures, processes and execution have been done in the right 
dimensions and context," Sheng writes. His argument is reasonable. But how can we guarantee that this happens?

In China, such reviews may be impossible at this stage of financial system development. Regulatory capturethat is, when a state regulatory agency created to act in the public interest

\section{For posterity's sake,} the Asian side of the story deserves to be told.

instead acts in favor of the commercial or special interests that dominate in the industry or sector it is charged with regulating - is common in China. What is needed now are regulators who focus on making and implementing rules, not making market choices. They should improve the trading system, monitor special interest groups, ensure adequate information disclosure, penalize offenders, and educate investors.

Yet Chinese regulators show little interest in these tasks. On the contrary, having been hijacked by powerful interest groups, they implement excessively protectionist policies in the name of safeguarding investor interests. This leads to artificial control of stock supply and demand and market distortion, which creates conditions that foster rentseeking by listed companies, turning investors into speculators. Sheng argues that "transparency is necessary but not sufficient." That's putting it mildly. In China, transparency is only a dream.

As Sheng points out, "The key structural problem faced by Asian economies is the legacy of a relatively closed, topdown silo governance structure faced with an open, rapidly changing and complex global market.” Exactly.

Sheng tells us that after the Asian crisis and the bursting of the dot-com bubble, the financial world undertook its most thorough overhaul since the 1930 s in areas that spanned accounting, corporate governance, regulation, and national financial sectors. But these measures were not enough to stem the latest crisis. In fact, some of these measures may have contributed to the crisis. And the world is still seeking answers to critical questions, including those surrounding the problem captured in the expression "too big to fail."

Still, there is hope for the future of financial oversight, even though events of the recent past do not portend well for the future. The logic of the rescue plan enhances the factors that create financial crises, including the current crisis. For example, the incentive mechanism in the financial sector and the principal-agent problem are all intact, if not worse, in the rescue plans. However, Sheng is hopeful. "No financial crisis is exactly alike, but there are common elements that would, I hope, help us identify and mitigate the next one," he writes.

Our challenges are especially serious in Asia, so Sheng's Asian regulatory perspective is particularly welcome at this juncture in market history. "There are very few books about the Asian crisis by senior Asian officials who were in place during the crisis," he notes. "For posterity's sake, the Asian side of the story deserves to be told."

Sheng deserves praise for being conscious of his responsibility to history. But his most valuable contribution is that he identifies some of the major barriers to a sound financial system and points the way toward future solutions.

Hu Shuli

Editor-in-Chief, Caixin Media, and Dean, School of Communication and Design, Sun Yat-sen University

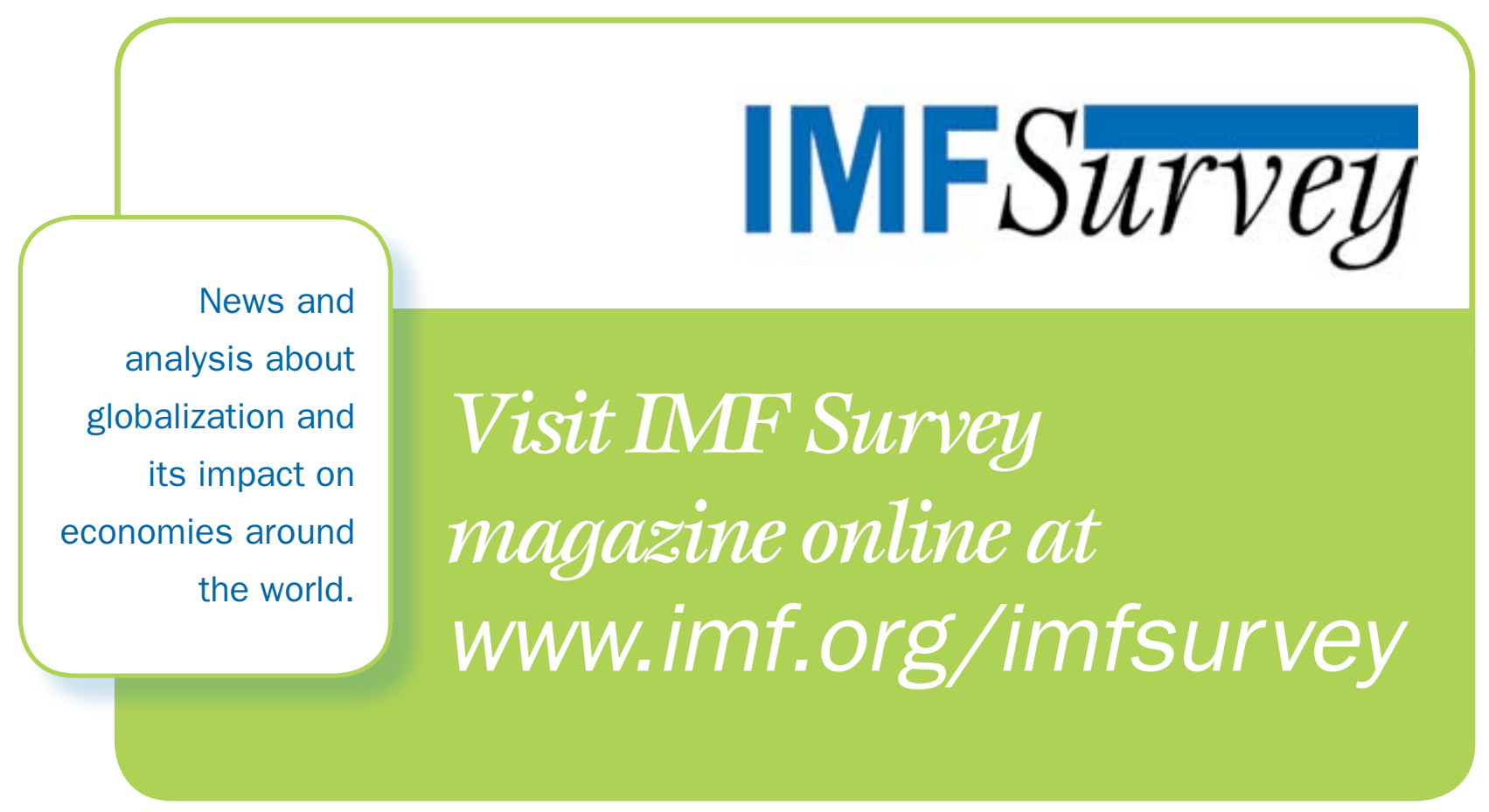




\section{Credit to the Private Sector Remains Weak

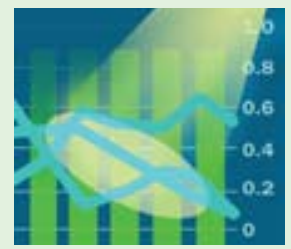

\section{Bank credit continues to fall despite the global recovery}

T. HE period preceding the international financial crisis of 2008 was characterized by excess global liquidity and a rapid expansion of credit, especially to the private sector. But as a consequence of the global crisis, the banking system cut back its lending to the private sector, as banks sought to improve balance sheets hit by declining asset prices, absorb a growing number of nonperforming loans and, in general, reduce risk by deleveraging. Bank credit growth has fallen sharply in real terms and is likely to remain subdued across most major economies and country groups.

A massive infusion of government funds and credit-easing policies in advanced economies, intended to fight a recession and support bank balance sheets, did not translate into increased credit to the private sector. After growing at an average annual rate of about 7 percent until mid-2008, bank credit growth in mature markets slowed and by the end of 2009 turned negative. Bank credit growth in 2009 dropped the most in the United Kingdom - by about 20 percent. In the United States, by early 2010 credit had fallen by almost 10 percent year on year. The euro area followed a similar trend.

Several factors explain why better financial conditions did not result in renewed credit growth to the private sector in these economies. First, as economic conditions weakened, demand for credit declined as firms cut output and households reduced consumption, decreasing their need for credit. Second, banks tightened lending standards in the face of greater uncertainty, weakening capital positions, and rising loan losses. Banks' balance sheets still remain under strain and funding conditions are becoming tighter. In a flight to quality, banks are favoring government bonds over loans to the private sector. And uncertainty about future regulation may be reducing banks' willingness to lend.

In emerging and developing economies, the region with the sharpest drop in credit growth is eastern Europe, which benefited from a substantial inflow of foreign funds and

\footnotetext{
About the database

The figures were compiled using monetary data reported by member countries to the IMF's Statistics Department for publication in International Financial Statistics. Real domestic banking sectors' claims on the private sector were calculated by deflating the nominal series by the consumer price index. Regional growth rates are weighted averages of individual countries' growth rates. Country groups follow the classification in the IMF's World Economic Outlook. The database is available at www.imfstatistics.org/imf
}

\section{Bank credit growth has yet to recover.}

(real bank credit to the private sector, percent, year-on-year)
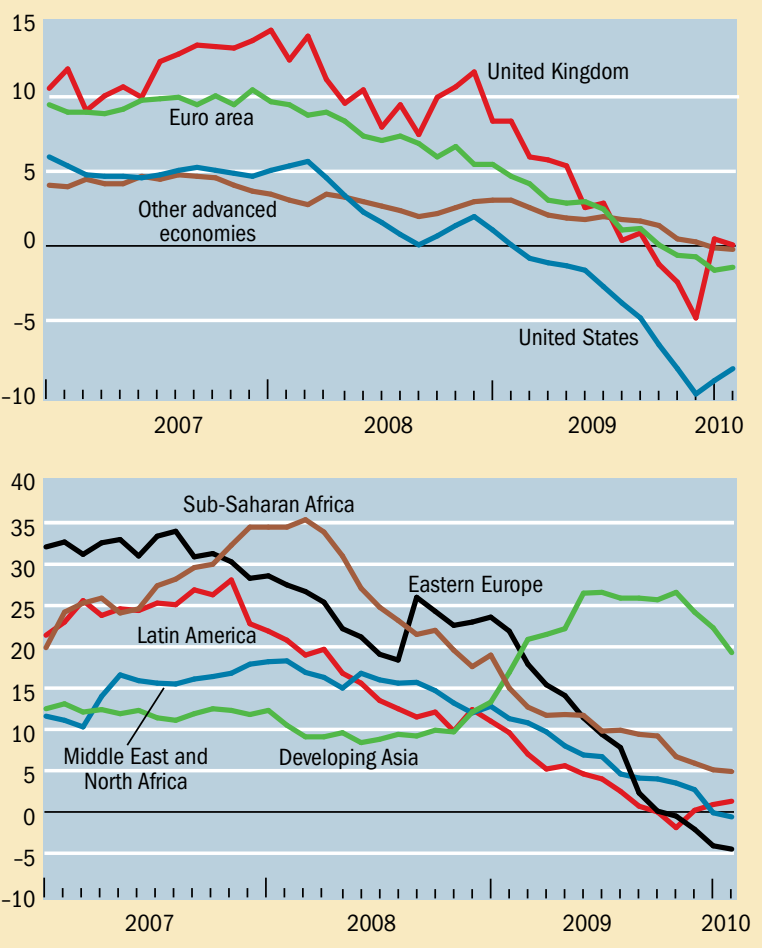

Source: IMF, International Financial Statistics.

cross-border lending prior to the crisis. When the financial crisis struck, credit growth dropped dramatically and has not started to recover, in part because of a reversal in foreign finance to the banking sector. Credit growth in Latin America, sub-Saharan Africa, and the Middle East and North Africa has been quite similar, with growth rates hovering between zero and 5 percent as of end-2009.

In contrast, credit to the private sector in emerging and developing Asia did not seem to be affected by the financial crisis. In fact, bank credit growth in these countries increased during the crisis and has only recently begun to fall. However, this development has been heavily influenced by China, where bank credit has grown steadily since 2005, reaching 35 percent by end-2009 owing to strong economic growth prospects and rising asset prices.

Prepared by José M. Cartas and Martin McConagha of the IMF's Statistics Department. 


\section{Expand your global expertise. Visit the IMF Bookstore.}

World Economic Outlook

The World Economic Outlook, packed with country-specific facts, figures, and worldwide projections, presents the outlook for growth, inflation, trade, and other economic developments in a clear, practical format.

\section{Just Released}

Exchange Rate Regimes and the Stability of the International Monetary System

This paper reviews the stability of the overall system of exchange rates by examining macroeconomic performance under alternative exchange rate regimes; exchange rate regime choice; and potential sources of stress to the international monetary system.

\section{Balance of Payments Manual, Sixth Edition}

This edition presents revised and updated standards for concepts, definitions, and classifications for international accounts statistics. These standards are used globally to compile comprehensive and comparable data.

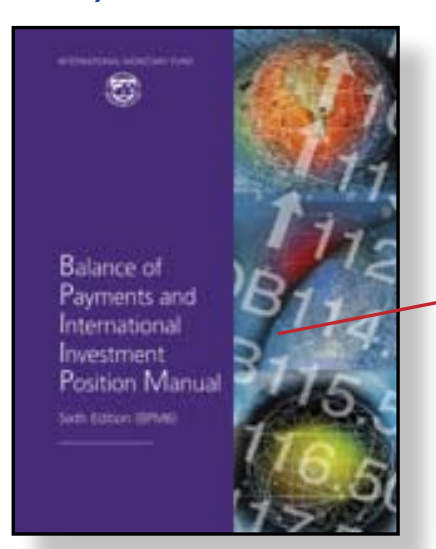

\section{Global Financial Stability Report}

The GFSR provides a deeper understanding of global capital flows by covering conditions in global financial markets. It highlights current issues that could affect international financial market stability.
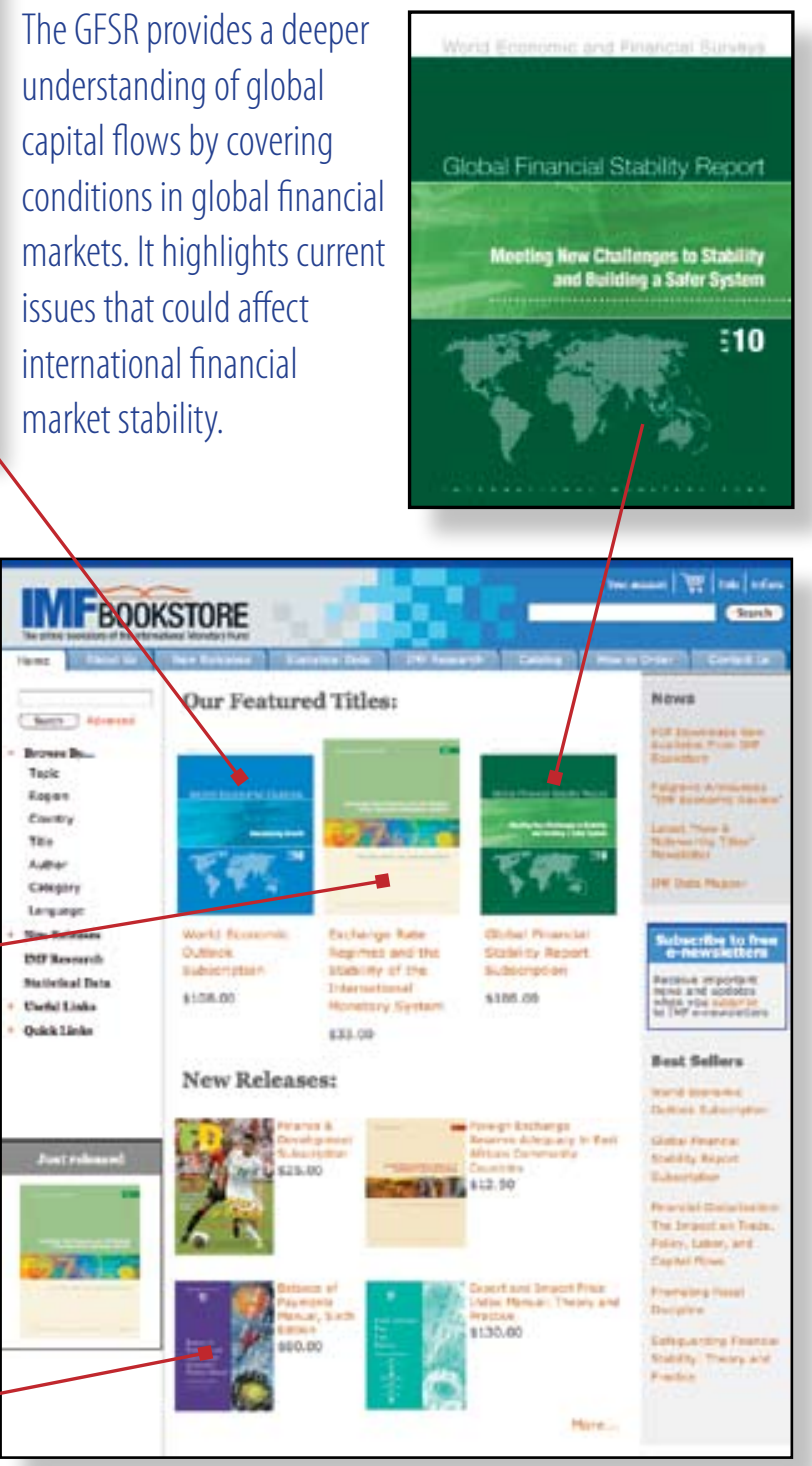

Order Now: Visit the IMF Bookstore today and browse to find the latest reports, publications, and data.

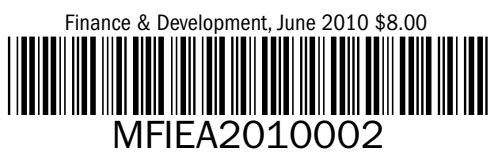

